\title{
ENTREPRENEURSHIP FACILITATORS AND THEIR ROLE IN POVERTY
}

\section{Alleviation}

\author{
By \\ Osama Aziz \\ BS-Accounting \\ University of Management and Technology, 2016 \\ A thesis presented to \\ Ryerson University \\ in partial fulfillment of the \\ requirements for the \\ degree of \\ Master of Science in Management \\ in the program of \\ Master of Science in Management \\ Toronto, Ontario, Canada, 2019 \\ (C) Osama Aziz, 2019
}




\section{AUTHOR'S DECLARATION FOR ELECTRONIC SUBMISSION OF A THESIS}

I hereby declare that I am the sole author of this thesis. This is a true copy of the thesis, including any required final revisions, as accepted by my examiners.

I authorize Ryerson University to lend this thesis to other institutions or individuals for the purpose of scholarly research.

I further authorize Ryerson University to reproduce this thesis by photocopying or by other means, in total or in part, at the request of other institutions or individuals for the purpose of scholarly research.

I understand that my thesis may be made electronically available to the public.

Osama Aziz 


\title{
ENTREPRENEURSHIP FACILITATORS AND THEIR ROLE IN POVERTY Alleviation
}

\author{
Osama Aziz \\ Master of Science in Management \\ Program of Master of Science in Management \\ Ryerson University, 2019
}

\begin{abstract}
Poverty is one of the main issues faced by countries across the world. Over the last three decades, governments and international organizations such as the World Bank, the IMF, etc. have been trying to reduce poverty. Despite this, today almost 2.5 billion people are still living in poverty. Entrepreneurship is often seen as a way to reduce poverty. Moreover, the role of entrepreneurship facilitators is very important in creating a suitable business environment for entrepreneurs which increases the capacity of entrepreneurial activities. The purpose of this thesis is to provide an insight into how entrepreneurial activity and entrepreneurship facilitators (Government, Incubators, and Financial Institutions) help in improving the business environment in all countries and hence in poverty alleviation, examining the impact in case of high-income, high mediumincome, medium-income, low-income countries and, as a result, reduce poverty. To investigate this, the Human Development Index (HDI) has been used to measure poverty. Secondary data for Entrepreneurship (Entrepreneurial Facilitators, Entrepreneurial Activities, and Economic Factors) and Poverty (HDI)) from the period of 2005 to 2016 are used for high-income countries, high medium-income countries, medium-income countries and low-income countries.

The study has found that there is a positive and significant relationship between entrepreneurial activity and the changes in Human Development Index (HDI) in all countries studied over the 12 years period. It also finds that the presence of good entrepreneurial facilitators improves the capacity of entrepreneurial activity which reduces poverty as measured by the HDI. It adds to the body of knowledge by using HDI as a new tool to analyze the impact of entrepreneurial activity country wise. It also suggests that governments need to make better business related regulations which will motivate entrepreneurs and create ease of business doing. Finally it suggests that trade openness bring foreign investments in a country which create employment for people.
\end{abstract}




\section{ACKNOWLEDGEMENT}

First of all I bow my head in gratitude to ALMIGHTY ALLAH, The Most Merciful and Compassionate for His blessings, Who blessed me with knowledge and enabled me to complete this thesis. I express my profound gratitude to my supervisor Prof. Dr. Kenneth A. Grant for guiding me in this research with patience and persistence. His constructive criticism and encouraging attitude throughout the research facilitated me and enabled me to accomplish my research in time. I am also grateful to Prof. Noman Arshed \& Prof. Dr. Ali Farhan Chaudhary for extending their help in data analysis, improvements and suggesting several corrections in a professional way. It will be unfair if I do not appreciate the support and encourage of my family throughout my studies. 


\section{DEDICATION}

Dedicated to my parents and my wife for their countless efforts and sacrifices who helped me to develop and also dedicated to my teachers for their directions and pieces of advice. Also dedicated to my dearest family members, my friends and all those who work hard for their achievements and believe that improvement is an endless process. Last but not the least, this thesis is dedicated to Professor Dr. Kenneth A. Grant. 


\section{TABLE OF CONTENTS}

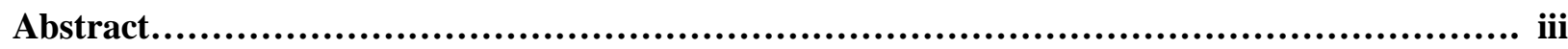

List of Tables......................................................................................viii

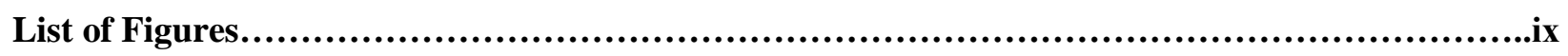

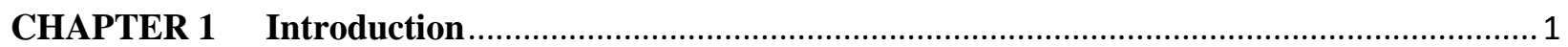

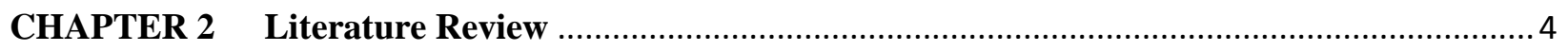

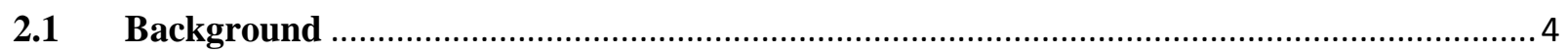

2.1.1 Poverty and the Potential Impact of Entrepreneurship .................................................. 4

2.1.2 Factors that Influence Entrepreneurship ............................................................ 7

2.1.3 The Characteristics of an Entrepreneur .................................................................. 9

2.1.4 The Impact of Government Policies on Entrepreneurial Activity ................................10

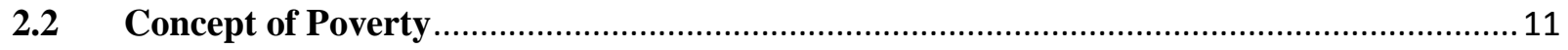

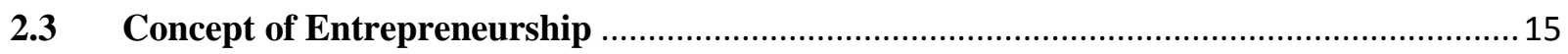

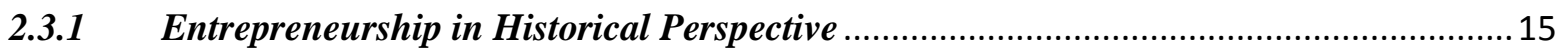

2.3.2 Definitions of Entrepreneurship ............................................................................ 16

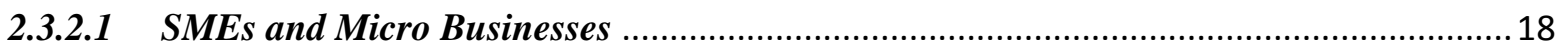

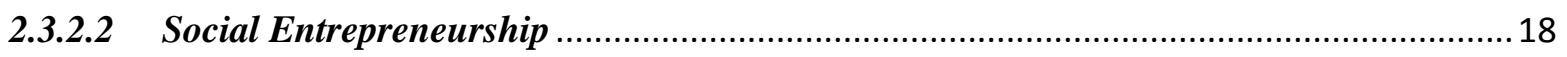

2.3.2.3 Self-employment vs. Small Businesses vs. Entrepreneurship ....................................... 18

2.3.3 Entrepreneurship through the Lens of Economics -- The Market View .......................19

2.3.4 Entrepreneurship and the Social Sciences -- Looking at the Individuals .....................20

2.3.5 Most Recent Prospective -- Entrepreneurship as a Process ........................................22

2.4 Relationship between Entrepreneurial Activity and Poverty ........................................22

2.4.1 Linking Entrepreneurship and Poverty Alleviation .................................................. 25

CHAPTER 3 Determining the Influence of Entrepreneurial Activity on Poverty Alleviation ......30

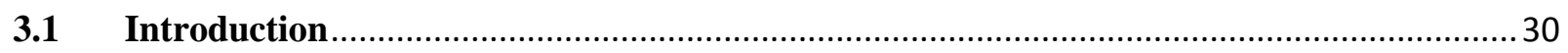

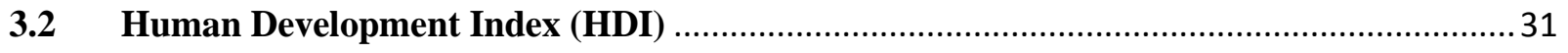

3.3 Entrepreneurship Facilitators and their role in alleviating poverty ................................32

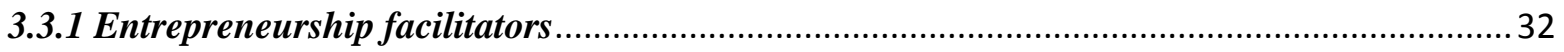

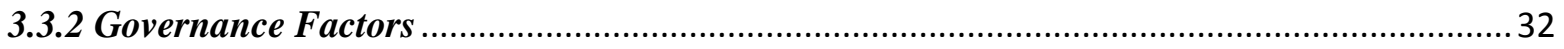

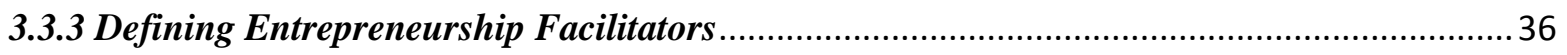

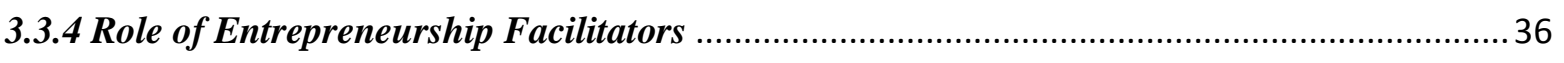

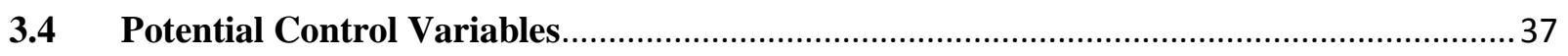


3.4.1 Relationship between Entrepreneurship and Economic Growth 37

3.4.2 Other Indicators and their role in Entrepreneurial Activities .......................................39

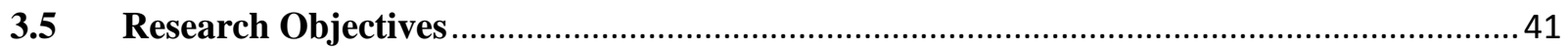

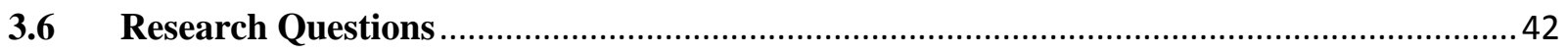

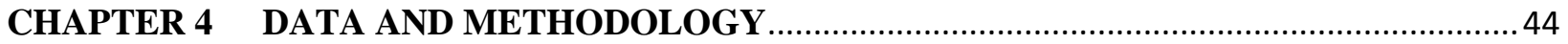

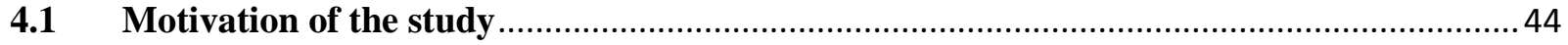

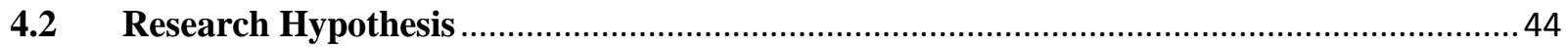

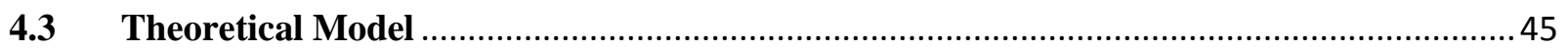

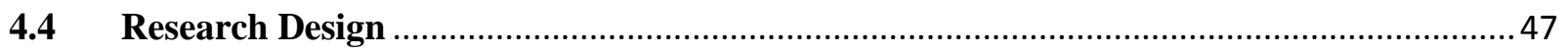

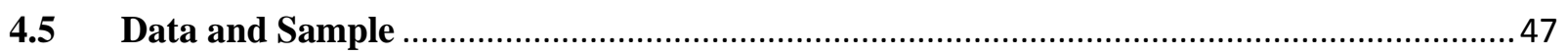

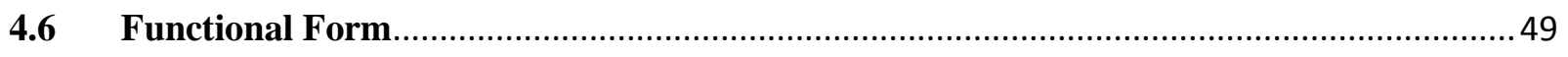

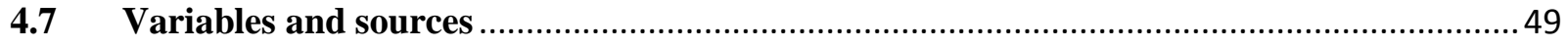

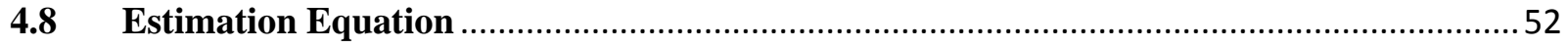

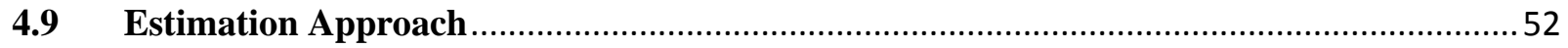

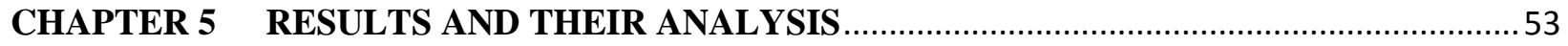

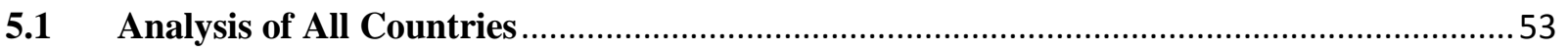

5.1.1 Estimation of Human Development Index (HDI) model of All Countries .....................55

5.2 Analysis of High-Income Countries..................................................................................5

5.2.1 Estimation of Human Development Index (HDI) model of High-Income Countries .....59

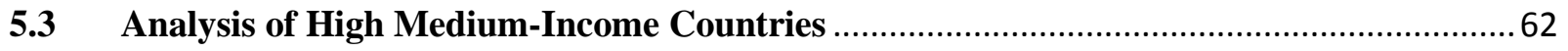

5.3.1 Estimation of Human Development Index (HDI) model of High Medium-Income

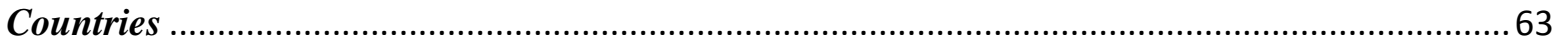

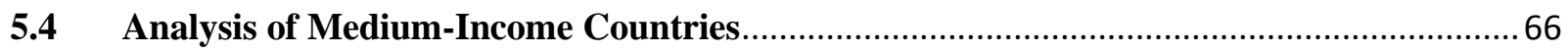

5.4.1 Estimation of Human Development Index (HDI) model of Medium-Income Countries 67

$5.5 \quad$ Analysis of Low-Income Countries …….................................................................... 70

5.5.1 Estimation of Human Development Index (HDI) model of Low-Income Countries ......71

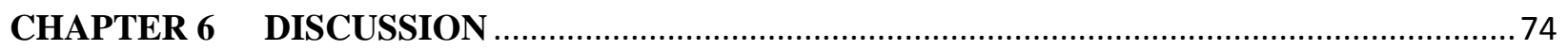

6.1.1 Overall Discussion of Human Development Index Model (HDI) ...............................75

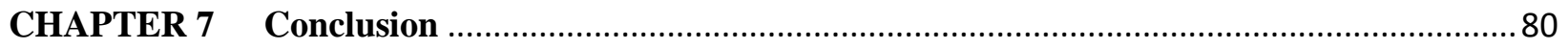

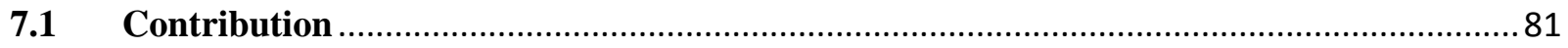

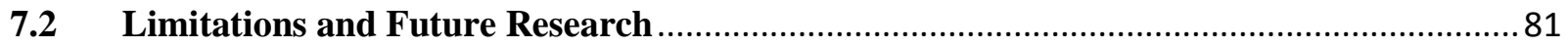

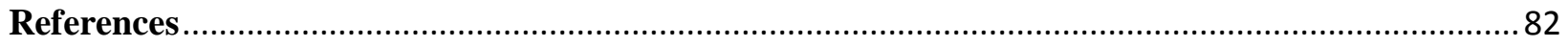




\section{List of Tables}

Table 2.1 Factors Effecting the Process of Entrepreneurship ............................................ 9

Table 2.2 Characteristics of Entrepreneurs ….................................................................... 10

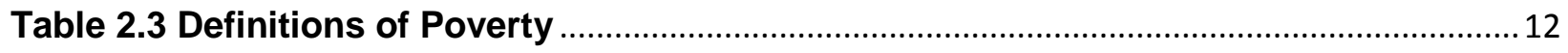

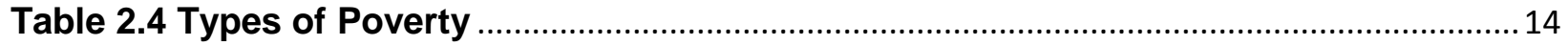

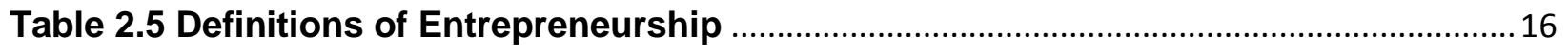

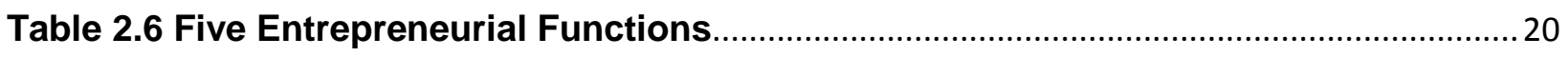

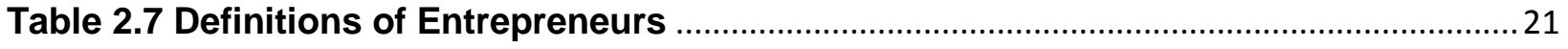

Table 2.8 Different School of thoughts about Entrepreneurship \& Entrepreneurs.............22

Table 2.9 Discussion of Economic Role of Startups and SMEs ...........................................26

Table 2.10 Discussion about the Effect of Education on Entrepreneurial Development....27

Table 4.1 All Countries segmented and ranked into High-Income, High Medium-Income,

Medium-Income and Low-Income

Table 4.2 Variables, Types, Definitions and Sources ......................................................... 51

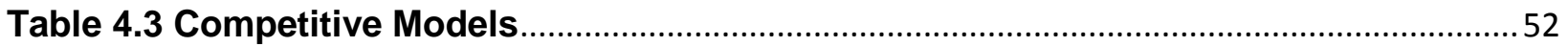

Table 5.1 All Countries segmented into High-Income, High Medium-Income, Medium-

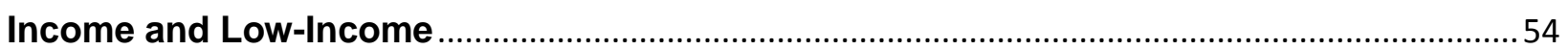

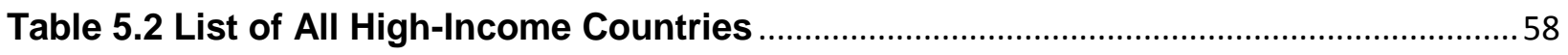

Table 5.3 List of All High Medium-Income Countries ..........................................................62

Table 5.4 List of All Medium-Income Countries .....................................................................6

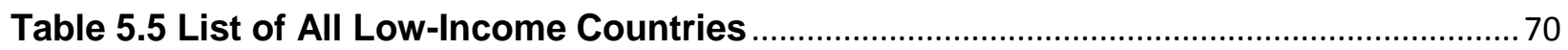

Table 6.1 Relationship between Human Development Index (HDI) and Independent Variables. 


\section{List of Figures}

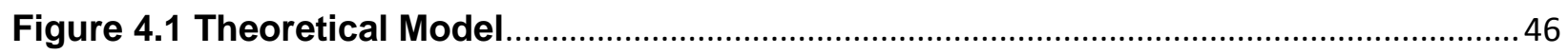

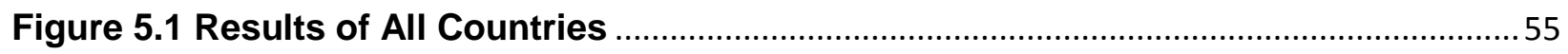

Figure 5.2 Results of High-Income Countries ...................................................................59

Figure 5.3 Results of High Medium-Income Countries ......................................................63

Figure 5.4 Results of Medium-Income Countries ..............................................................67

Figure 5.5 Results of Low-Income Countries ............................................................................ 71 


\section{CHAPTER 1}

\section{Introduction}

It has long been realized that poverty is one of the main issues that every developing country faces in its severe form, which is one of the major retarding factors in the economic growth and development of the country (Bruton, Ketchen, \& Ireland, 2013). The World achieved the Millennium Development Goal of reducing poverty rate to half of the set target by 2015 (United Nations, 2015). According to the World Bank (2016, para. 2), "despite the development made in decreasing poverty, the total number of individuals living in extreme poverty globally stays high. Today, the total population living in poverty is 2.47 billion and poverty is defined as those surviving with a daily income of US\$ 2.0 or less. By estimating global growth, poverty reduction may not be fast enough to reach the World Bank's target of ending extreme poverty by 2030." Every country is suffering with different form of poverty. That is why the definition of poverty in developed, developing and underdeveloped countries are different. Entrepreneurship offers different workable techniques and methods to break the cycle of poverty (M. D. Hussain, Bhuiyan, \& Bakar, 2014).

In the last three decades, governments and international organizations such as World Bank, IMF etc. have been trying to reduce poverty (Stiglitz, 2002). Ill-conceived government policies of some countries have been obstacles in resolving extreme poverty issues in countries like Malawi, Ghana and Afghanistan. Because of inadequate health facilities, the life expectancy in such countries is low. By improving health services, investing on education, improving the quality of legislation, the government can motivate people to become entrepreneur, which will be a right step in reducing the ratio of extreme poverty in a country (Alvarez \& Barney, 2014; J. Sachs, 2005).

Entrepreneurship is one of the oldest human activities. This activity is focused on identifying new opportunities and using those opportunities in a new business venture for monetary gain (Landstrom, 2007). Entrepreneurship is a process where an individual uses his skills to identify the opportunities and use resources and innovation to create value and fulfil the needs of those opportunities (Coulter, 2001). Moreover, entrepreneurship helps an individual or individuals to become creative within the environment and generate profit by exploiting the opportunities (Timmons \& Spinelli, 2004). According to Kuratko and Hodgetts (2004, p. 30), "Entrepreneurship is a dynamic process of vision, change and creation." 
Moreover, a business enterprise is a way of making something significant by dedicating the fundamental aptitudes, time and efforts to achieve profit and personal satisfaction (Hisrich \& Peters, 1989). Entrepreneurship can help in the growth of the economic development positively and alleviate poverty by creating more jobs, allowing more people to become an entrepreneur and improve the standard of life by providing the poor an access to the basic goods and services (Mead \& Liedholm, 1998)

Entrepreneurial activities have both financial and non-financial benefits. Some of the nonfinancial benefits are individual satisfaction, intrapreneurial learning experience, successful creation and expansion of new ventures, increase in employee numbers, improve the standards of living and improve employment rates (Luke, Verreynne, \& Kearins, 2007). Whereas, some of the financial benefits of entrepreneurial activities in organizations and businesses are, "revenue generation, wealth accumulation, profitability, GDP growth, increase in taxation and welfare." (Luke et al., 2007, p. 325). Productive entrepreneurial environment is presumably thought to have an instrumental role in flourishing the economy by venturing into advanced business techniques paving the way for employment generation (Bhagwati \& Srinivasan, 2002).

Every country strives hard to improve the financial well-being of its general public and explores the effectiveness of several indicators for achieving this goal (Okpara, 2011). This thesis examines the entrepreneurship and entrepreneurship facilitators (Government, Incubators, and Financial Institutions) and their role in poverty alleviation by comparing high-income, high medium-income, medium-income and low-income countries as per United Nations Development Program grouping.

In order to understand the role of entrepreneurship in alleviating poverty, there is a need to review the existing evidence, theories, and barriers that impede the economies to relieve the burden of poverty. The objective of this thesis is to provide an insight into entrepreneurship itself and entrepreneurship facilitators (Government, Incubators, and Financial Institutions) and how these facilitators help in improving the business environment of all countries which ultimately play a significant role in alleviating poverty. To answer these questions, secondary data for Entrepreneurship (Entrepreneurial Facilitators, Entrepreneurial Activities, and Economic Factors) and Poverty (Human Development Index (HDI) and Gross National Income (GNI)) of the period of 2005 to 2016 is used for high-income countries, high medium-income countries, mediumincome countries and low-income countries (UNDP, 2018). 
Furthermore, this thesis has been divided into six chapters. Chapter 2 is about literature review. Chapter 3 is about determining the influence of entrepreneurial activity on poverty alleviation, Chapter 4 is about data and methodology. Chapter 5 is shows results and their analysis. Chapter 6 is about discussion and chapter 7 is about conclusion. 


\section{CHAPTER 2 \\ Literature Review}

\subsection{Background}

\subsubsection{Poverty and the Potential Impact of Entrepreneurship}

Poverty is one of the main issues that adversely affects the lives of many individuals and the economy of every country. Almost 2.5 billion people are living below the poverty line, surviving at the income of US $\$ 2$ or less a day (Bruton et al., 2013). However, according to Lant, Klasen, Alkire, Lenhardt, and Letouzé (2013), to determine the level of poverty $\$ 1.25$ a day is not appropriate level. The suitable level to measure poverty should be $\$ 10$ a day. Singer (2006) states, "Poverty means lack of confidence, income, lack of access to goods and services and disempowerment." The best way to alleviate poverty and assist people is to give them an access to the basic human capital i.e. education, health, shelter. Many argue that this object can be achieved by starting new ventures and business activities through entrepreneurship (Singer, 2006).

In Asia, China which is a high medium-income country, has been successful in poverty alleviation. After the dramatic turmoil of Mao era, 90\% of the Chinese population (approximately 900 million) were living in abject poverty. With the passage of time, Chinese reforms helped poor people to improve their life (Clark, 2011). Such reforms reduced the total number of people living in abject poverty (Ahlstrom, Levitas, Hitt, Dacin, \& Zhu, 2014).

Recently, scholars have investigated possible root causes of poverty and have offered some theories to mitigate it. Scholars from other business-related disciplines such as economics, entrepreneurship, finance and management have been investigating poverty for many years and entrepreneurship scholars have recently started to pay attention to poverty and have offered different approaches and methodologies to alleviate poverty (Bruton et al., 2013).

As Goldsmith and Blakely in 1991 stated, "There are three different categories of poverty in which people are living i.e. poverty caused by disease, poverty caused by some tragic incident and poverty caused by the system" (W. Goldsmith \& Blakely, 1991, p. 18). However, Rank has a different point of view as he says that "The concentration on individual characteristics as a cause of poverty is misdirected." (Rank, 2004, p. 79). 
Evidence exists that governments and financial institutions have always tried to address the problem of poverty specifically from an educational perspective (Kolvereid \& Moen, 1997). However, historically researchers and scholars paid less attention to poverty and even the definition of entrepreneurship was not discussed in the context of poverty. Scholars have been trying to explain entrepreneurship in various perspectives. Schumpeter (1942) developed the idea of creative destruction which is the process of destroying something by bringing something new at its place. Shane and Venkataraman (2000) discussed the opportunities utilized by entrepreneur or an individual to create future goods and services. Rindova, Barry, and Ketchen (2009) gave slightly different concept of entrepreneuring as the effort by an individual to bring new cultural, social and economic environment. McMullen (2011) identified that market-based approach can help a person to overcome poverty.

Schumpeter proposed the concept of "creative destruction" to explain the market dynamics where firms or individuals engage each other in a competition. Such competition is good for economic benefit (Schumpeter, 1934). An efficient business environment will enhance the productivity of the firms which will create more jobs and economic growth (Ahlstrom, 2010). The remarks of Schumpeter on ineffective allocation of investments is that, "Add successively as many mail coaches as you please, you will never get a railway..." (Schumpeter, 1934, p. 64). New business enterprises and innovation plays a vital role for the development of economic growth and alleviating poverty (Schumpeter, 1934; Sombart, 2013).

One of the main factors which has limited research to investigate poverty alleviation through entrepreneurship is that the most of the scholars who worked in this field came from developed countries (Europe and North America) where poverty has never been as central issue. That is why their theories do not explain the extent and depth of poverty which is rampant in developing and under developed countries. Kareem (2015) who comes from a developing country discussed different success factors through entrepreneurship. According to Kareem (2015, p. 5), "The more common factors of entrepreneurship to alleviate poverty include psychological factors (intelligence, creativity, motivation for autonomy and affiliation), individual factors (education, knowledge of the market and business, family background and age), socio-cultural factors (tensions in the society, religious values in society and social structure), and opportunity factors (economic opportunities, guided entrepreneurship, current programs of entrepreneurial training, peer group assistance and access to finance)." Kareem also explains some reinforcing factors 
which help a person to become a successful entrepreneur i.e. self-motivation for achievement, business related skills, an understanding of the market forces, self-confidence, social and government policies.

Shane (2008) explains that entrepreneurship helps countries to develop a mechanism for economic growth which creates employment and generates business opportunities. Chiles, Bluedorn, and Gupta (2007) stress that entrepreneurs should learn new skills and enhance their capacity to serve people in a better way. These entrepreneurial activities will lead to the acquisition and use of new technologies, enrich the administrative strategies and help the organizations to fulfill the needs of their customers effectively (Draft \& Marcic, 2006).

Luke, Verreynne, and Kearins (2007) explained that entrepreneurial activities have both financial and non-financial benefits. Some of the non-financial benefits are, "individual satisfaction, intrapreneurial learning experience, successful creation and expansion of new ventures, increase in employee numbers, improve the standards of living and improve employment rates. Whereas, some of the financial benefits of entrepreneurial activities in organizations and business are, "revenue generation, wealth accumulation, profitability, GDP growth, increase in taxation and welfare.” (Luke et al., 2007, p. 325).

Storey (1994) suggested three key components which develop the process of entrepreneurial activities. The first component is the entrepreneur who possesses high motivation, good educational background and business related family background. The second component is the organization of the business which includes the resources, ability to exploit the available opportunity and generate profit and make strategic choices. The third component is the environment which includes those factors which create ease for entrepreneurs and organizations in carrying out the business activities.

It is often argued that there are five factors which play a vital role in motivating an entrepreneur to be a successful businessman. These factors are moral uprightness, steadfastness, social integration, educational background and practical experience (Ronstadt, 1983; Vesper, 1979). Keats and Bracker (1988) explained that there are different variables related to environmental and personal characteristics which influence the whole process of entrepreneurship. They suggest that entrepreneurial intent is one of the main variables which plays an essential role in the success of an organization. 
Moreover, Ronstadt (1983) and Vesper (1979) illustrated the factors which help organizations to achieve their goals and vision. These factors are entrepreneurial intensions, work evolvement, psychological attributes, entrepreneurial plan (Keats \& Bracker, 1988) and individual qualities and aptitudes. Entrepreneurship can alleviate poverty by creating more jobs, allowing people to have self-employment, empowerment to the middle class and enhance the economy of the country (Si et al., 2015).

Peteraf (1993) identified that the key capabilities which are essential for the development and accomplishment of a business organization are effective use of resources, capability to identify resources and opportunities, gain and sustain the competitive advantages. Similarly some authors suggested that there are tangible resources (profits, access to finance, and funds) and intangible resources (knowledge, entrepreneurial orientation, employees' motivation and skills) which are essential in running the operations of the business. (Barney, 1991; Peteraf, 1993; Runyan, Huddleston, \& Swinney, 2006; Wernerfelt, 1984) Moreover, Burgelman (1983) and D. Miller (1983) illustrated that organizational structure and core strategies are also an important factors for the development of a business organization. The development of such an organization helps to create more job opportunities, business environment, motivates other people to become an entrepreneur and enhance the growth of the GDP (D. Miller, 1983).

\subsubsection{Factors that Influence Entrepreneurship}

Before starting a business, entrepreneurs have to consider internal and environmental factors. Environmental factors play a vital role for business enterprises to thrive. Before initiating a business plan, an entrepreneur will seek in depth knowledge about the sector and its condition in which the product will be launched such as customers' needs, suppliers' network and his/her potential to create a value product which can make an imprint in the market and attract customers to itself. Similarly, a conducive business environment helps the entrepreneurial process to be successful by providing, “capital, human resource and infrastructure.” (Jain \& Ali, 2013, p. 124).

Business environment and organizational activities may affect the decision making skill of an individual (Acs, Autio, \& Szerb, 2014; Peng, 2002; Peng, Sun, Pinkham, \& Chen, 2009). Better institutional structure will allow an individual to make effective decisions which will enhance entrepreneurial activity (Levie \& Autio, 2011; Stenholm, Acs \& Wuebker, 2013). Autio and Fu (2015) examined the role of nation's politics on formal and informal entrepreneurship. Evidence 
showed that informal entrepreneurs do not register their businesses. Informal entrepreneurs includes those people who have their own small businesses with none or a few employees working with them. Informal entrepreneurs play a vital role in the creation of new jobs in market which will enhance the economy of the country and help the country in its efforts to mitigate poverty (Bowen \& Clercq, 2008; Estrin \& Mickiewicz, 2012; Williams \& Nadin, 2010).

According to Ronstadt (1983), there are three types of environmental factors which affect the process of entrepreneurship which are given below:

- The first is the industrial environment which includes the behavior of competitors and competition amongst competitors in providing better product/services.

- The second is the neighborhood conditions where entrepreneurs are going to launch and operate their businesses.

- The third is the political environment which can affect the business activities at national or international level depending on nature of the business.

Moreover, Gnyawali and Fogel (1994) also suggested that there are five factors which create an entrepreneurial environment:

- Access to finance (government programs, low interest loans, and financial institutions).

- Business skills (entrepreneurial education and entrepreneurship training).

- Regulatory quality (government policies and procedures regarding trading restrictions and regulations to register a business).

- Socioeconomic condition (people with entrepreneurial knowledge and experience, public behavior and approach towards entrepreneurship).

- Non-Financial assistance (entrepreneurial network and support services).

Furthermore, Brandstätter (1997) illustrated that economic condition can affect the government regulatory quality, behaviour of entrepreneurs, socioeconomic conditions and access to finance. So the level of entrepreneur's attitude, motivational level, capacity to exploit opportunities in nature around him will help to generate profit to contribute towards the economic growth of the country (Brandstätter, 1997).

Hollingsworth, Abner, and Herbert (1979) perceived that better government legislations on taxations will enhance the entrepreneurial activities. The role of environmental dynamism is important in the success, formation, growth, performance and survival of a business and impacts 
sales of new and existing ventures greatly (Bamford, Dean, \& McDougall, 2000; Dean, 2016; Eisenhardt \& Schoonhoven, 1990; A. Miller \& Camp, 1985; Romanelli, 1989). According to Shapero \& Sokol (1982) the creation of entrepreneurial events is based on a social framework which promotes innovations, risk-taking and independence. Table 2.1 summarizes the views discussed above.

Table 2.1 Factors Effecting the Process of Entrepreneurship

\begin{tabular}{|c|c|c|}
\hline Authors & Years & Factors \\
\hline Hollingsworth, Abner, and Herbert & 1979 & Government Legislation \\
\hline Ronstadt & 1983 & $\begin{array}{c}\text { Industrial Environment, Neighborhood Conditions and Political } \\
\text { Environment }\end{array}$ \\
\hline Gnyawali and Fogel & 1994 & $\begin{array}{c}\text { Access to Finance, Business Skills, Regulatory Quality, Socioeconomic } \\
\text { Condition, and Non-Financial Assistance }\end{array}$ \\
\hline Brandstätter & 1997 & Economic Condition \\
\hline Levie and Autio & 2011 & Institutional Structure \\
\hline Stenholm, Acs and Wuebker & 2013 & Institutional Structure \\
\hline
\end{tabular}

\subsubsection{The Characteristics of an Entrepreneur}

In the process of entrepreneurship, an individual with entrepreneurial attributes can play a vital role in the creation and development of new ventures (Ronstadt, 1983). According to Venkataraman (1997), an entrepreneur requires practical knowledge and required skills to identify and exploit opportunities in nature. Entrepreneurship process tends to encourage entrepreneurs and allow them to gain financial benefit. There is a direct relationship between entrepreneurial behavior and personality traits of an individual. (Cooper, Woo, \& Dunkelberg, 1988; Dunkelberg \& Cooper, 1982; Hornaday \& Aboud, 1971; McClelland, 1987; Solomon \& Winslow, 1988).

According to Jain and Ali (2013), the characteristics which are important for an individual in the process of becoming an entrepreneur are: creativeness, self-efficacy, innovativeness and risk taking. Environmental factors also play a role of facilitators for an individual to be successful in entrepreneurial process. Social networking is important for an individual to strengthen the selfefficacy (Timmons, 1978).

Education, work experience and societal interaction are necessary to help a person to act as an entrepreneur and achieve entrepreneurial success (C. C. Chen, Greene, \& Crick, 1998; Guth \& Arun, 1991; Neck \& Manz, 1992; Norris F. Krueger \& Brazeal, 1994). Such competencies will increase the chances of a person to become a successful entrepreneur (Jain \& Ali, 2013). Entrepreneurial opportunity is an important factor in the success of business enterprise in every environment. A person uses their vision, knowledge and skills to identify an opportunity and utilize 
resources to exploit that opportunity with the purpose of generating profit. There will always be an opportunity available in the given environment but it depends on the person's ability to exploit that opportunity. It means how that person identifies the opportunity, available conducive environment and strategy to get financial benefit out of that opportunity (Chandler \& Hanks, 1994; Shane, 2003). Table 2.2 shows the characteristics of entrepreneurs as discussed above by scholars.

Table 2.2 Characteristics of Entrepreneurs

\begin{tabular}{|l|c|c|c|c|c|c|c|}
\hline \multicolumn{1}{|c|}{ Authors } & Year & $\begin{array}{c}\text { Practical } \\
\text { Knowledge }\end{array}$ & Creativity & $\begin{array}{c}\text { Self- } \\
\text { efficacy }\end{array}$ & Innovative & $\begin{array}{c}\text { Risk- } \\
\text { taking }\end{array}$ & $\begin{array}{c}\text { Social } \\
\text { Networking }\end{array}$ \\
\hline Timmons & 1978 & & & $X$ & & $X$ \\
\hline Guth and Arun & 1991 & $\mathrm{X}$ & & & & $\mathrm{X}$ \\
\hline Neck and Manz & 1992 & $\mathrm{X}$ & & & & \\
\hline Venkataraman & 1997 & $\mathrm{X}$ & $\mathrm{X}$ & & & & \\
\hline $\begin{array}{l}\text { C. C. Chen, Greene, and } \\
\text { Crick }\end{array}$ & 1998 & $\mathrm{X}$ & & & & & \\
\hline Jain and Ali & 2013 & & $\mathrm{X}$ & $\mathrm{X}$ & $\mathrm{X}$ & $\mathrm{X}$ & \\
\hline
\end{tabular}

Many scholars have found that the level of ability of a person to recognize an opportunity depends on their previous work experience, educational level, knowledge of the business environment and experience of dealing with customer problems (Cooper, Woo, \& Dunkelberg, 1989; Davidsson \& Honig, 2003; Ucbasaran, Wright, \& Westhead, 2003; Shepherd \& DeTienne, 2005). Such factors help a person to enhance their ability to identify an opportunity and exploit that opportunity to yield profit. Moreover, their level of confidence is also important in taking decisions and developing strategies to exploit opportunities (Cooper et al., 1988; Kaish \& Gilad, 1991; Kahneman \& Lovallo, 1993; Krueger \& Dickson, 1994; Busenitz \& Barney, 1997).

\subsubsection{The Impact of Government Policies on Entrepreneurial Activity}

Branstetter, Lima, Taylor, and Venâncio (2014) found that ill-conceived government policies can hold back people from starting a business or demotivate people from starting a business which can hinder healthy entrepreneurial activities. Such policies can constraint the economic development of a nation. Many scholars have investigated the relationship between business entry parameters set by government and level of corruption and its impact on entrepreneurial activity (De Soto, 1989; Djankov, La Porta, Lopez-de-Silanes, \& Shleifer, 2002). Strict entry regulations of a country can restrict the entry of new firms and business enterprises to enter and play their role in economic development of that nation (Ciccone \& Papaioannou, 2007; Fisman \& Allende, 2010).

According to De Soto (1989), strict and vague entry regulations for a new business only benefit politicians and bureaucrats and can allow them to take bribes from new business entrants 
while implementing entry regulations. Regulations should promote and motivate people to start a business by offering business friendly environment and simplified regulations for new entrants (Stigler, 1971; Posner, 1975; Peltzman, 1976). Moreover, Pigou (1938), suggested that the goal of regulations should be setting an standard which every firm has to meet in term of better services, quality of products and etc. Barseghyan (2008) also agree that complex entry regulations have only negative impact on economic growth and job creation environment of a country.

For many entrepreneurs, the population living in poverty can be seen as a potential market in which selling their different goods and services will generate profit. According to Prahalad (2005) firms or entrepreneurs can generate a better return on investment (ROI) by serving the needs of the people living in poverty. However, Bruton (2013) suggested that instead of focusing on the poor people as a market, businessman should focus on entrepreneurship which allows poor people to break the poverty cycle by taking benefits from the different means of entrepreneurship (Bruton et al., 2013).

\subsection{Concept of Poverty}

As discussed earlier, one of the main challenges which developed and developing countries are facing today is poverty. This section provides further discussion and explanation of the concept of poverty. Todaro and Smith suggested that, "A person is in poverty if, a person is suffering with hunger, he does not have any shelter, at the time of sickness he is not able to see a doctor, he does not have any access to the schools, he doesn't know how to read and he does not have any job." (Todaro \& Smith, 2012, p. 23). Every country sets their own poverty line depending on their economic situation and government policies. Countries use certain tools to determine their poverty line such as Low-Income Cut-offs (LICO), Basic Needs Parameters, Market Basket Measure, Absolute Measure and Relative Measure (Parliament of Canada, 2008).

Many people are living below the poverty line in developing and underdeveloped countries. Many scholars have explored the factors causing poverty. Arshed, Alamgir, and Aziz (2017), explained that family size, level of education and job characteristics are three things which can forces an individual to be a poor. They have also identified various categories of entrepreneurship and other social determinants that are helpful in alleviating poverty and improving the lives of poor people (Seelos \& Mair, 2005). Moreover, entrepreneurship helps to change the business environment of a country which ultimately plays a positive role in the wellbeing of the general 
population of a country especially those living below the poverty line. The creation and promotion of new ventures and business activities in a country will reduce the reliance of that country on foreign direct investment (FDI) (Mitra, Abubakar, \& Sagagi, 2011). Such entrepreneurial activities allow the poor people to become economically independent and stimulate them to have income empowerment (Adenutsi, 2009).

The definition of poverty in developed countries is different from that used in developing countries. For example, in developing countries the meaning of poverty is "lack of shelter, lack of food, lack of health and lack of education facilities." (Singer, 2006, p. 226). According to Lammam and Maclntyre there are two ways through which poverty has been defined in developed countries, "Level of resources needed to purchase a family's basic needs" (Lammam \& Maclntyre, 2016, p. 3 ) and "A situation in which someone is relatively worse off than other members of society" (2016, p. 2).

In developed countries where people have access to basic goods and resources, unemployment is the main issue which doesn't allow a person to enjoy the prevalent standard of life in that country. Thus two main reasons which might cause a person to be unemployed are lack of proper education and skills and lack of opportunity. Lack of proper education and required skills will restrict a person to apply for limited categories of jobs and face high competition, whereas, lack of opportunity means a person has a required education and skills but few job opportunities are available in the market (Shahid, Deaton, Dervis, \& Easterly, 2009). Table 2.3 shows the definitions proposed by authors to understand poverty in developed, developing and underdeveloped countries.

Table 2.3 Definitions of Poverty

\begin{tabular}{|c|c|c|}
\hline Authors & Year & Definitions \\
\hline $\begin{array}{c}\text { Todaro and } \\
\text { Smith }\end{array}$ & (2012, p. 23) & $\begin{array}{c}\text { Underdeveloped Countries } \\
\text { "A person is in poverty if, a person is suffering with hunger, he does not have } \\
\text { any shelter, at the time of sickness he is not able to see a doctor, he does not } \\
\text { have any access to the schools, he doesn't know how to read and he does not } \\
\text { have any job." }\end{array}$ \\
\hline \multicolumn{2}{|c|}{\begin{tabular}{c} 
Developing Countries \\
\hline Singer
\end{tabular}} & $\begin{array}{c}(2006, \text { p. 226) } \\
\text { "Lack of shelter, lack of food, lack of health and lack of education facilities." }\end{array}$ \\
\hline $\begin{array}{c}\text { Lammam and } \\
\text { Maclntyre }\end{array}$ & $(2016$, p. 2) & "A situation in which someone is relatively worse off than other members of \\
society." \\
\hline $\begin{array}{c}\text { Lammam and } \\
\text { Maclntyre }\end{array}$ & $(2016$, p. 3) & "Level of resources needed to purchase a family's basic needs" \\
\hline
\end{tabular}


Jensen (2009, para. 3) proposes six types of poverty:

- Situational poverty

- Generational poverty

- Absolute poverty

- Relative poverty

- Urban poverty

- Rural Poverty

Two types which are commonly found in almost all countries (developed and developing) are absolute poverty and relative poverty. According to Hussain, Bhuiyan and Bakar (2014, p. 560), "absolute poverty is explained as lack of resources to meet the physical needs for survival and relative poverty is explained as being worst off than average."

According to Sachs (2005), half of the world's population is poor. Sachs identifies three types poverty: extreme poverty, moderate poverty and relative poverty. For Sachs, extreme poverty includes people whose income is less than $\$ 1$ a day. People living in extreme poverty do not have access to clean water. They have no shelter, no proper health facilities, and no basic education and are suffering from hunger. Extreme poverty exists in some developing countries and many developing countries such as Bangladesh, Pakistan, India and Indonesia and most parts of Africa such as Mali, Ghana, Senegal and Malawi. Moderate poverty includes people whose income is $\$ 1$ to $\$ 2$ and they do not have adequate access to the basic needs. Moreover, people living in moderate poverty do not have enough wealth to provide their children with better health and education facilities. Relative poverty includes those people whose household income is below the barrier set by the nation based on other people's income in same region. People living in this category may have access to basic education, health and other entertainment but lag behind in quality services.

Usually, developed countries such as Canada and the U.S. establish a benchmark of minimum income calculated by considering the household income of all middle class people living in that region (Cauthen \& Fass, 2008). Typically, government, NGO's and other organizations have some programs through which they help people living in relative poverty to improve their standard of living.

According to Sachs (2005), the U.S. has allocated a budget spend of about $\$ 500$ billion in 2018 on their military, pointing out that if the U.S. just spend $0.15 \%$ of their total income which 
is almost $\$ 16$ billion to eradicate extreme poverty than U.S. could alleviate extreme poverty in developing and under developed countries by 2025.

According to Parliament of Canada (2008, para. 1) absolute poverty is, "The amount of income needed by a household to purchase a basket of specified goods and services that are deemed to meet the basic needs of an average household. On the other hand, a "relative measure" may compare the total income of a particular household against the income level defined as the poverty line for an average household of similar size in a similar community." Table 2.4 summarizes different types of poverty as discussed above.

Table 2.4 Types of Poverty

\begin{tabular}{|c|c|c|c|}
\hline Authors & Year & Types & Definitions \\
\hline Jensen & (2009, para. 4) & $\begin{array}{l}\text { Rural } \\
\text { Poverty }\end{array}$ & $\begin{array}{l}\text { "Rural poverty occurs in nonmetropolitan areas with populations } \\
\text { below } 50,000 \text {. In rural areas, there are more single-guardian } \\
\text { households, and families often have less access to services, } \\
\text { support for disabilities, and quality education opportunities." }\end{array}$ \\
\hline Jensen & (2009, para. 4) & $\begin{array}{l}\text { Urban } \\
\text { Poverty }\end{array}$ & $\begin{array}{l}\text { "Urban poverty occurs in metropolitan areas with populations of at } \\
\text { least } 50,000 \text { people. The urban poor deal with a complex } \\
\text { aggregate of chronic and acute stressors (including crowding, } \\
\text { violence, and noise) and are dependent on often-inadequate large- } \\
\text { city services." }\end{array}$ \\
\hline $\begin{array}{l}\text { Payne, } \\
\text { Philip, and } \\
\text { Smith }\end{array}$ & $(2001$, p. 18) & $\begin{array}{l}\text { Situational } \\
\text { Poverty }\end{array}$ & $\begin{array}{c}\text { "Situational poverty involves a shorter time and is usually caused } \\
\text { by circumstance (i.e., death, illness, divorce)." }\end{array}$ \\
\hline $\begin{array}{l}\text { Payne, } \\
\text { Philip, and } \\
\text { Smith }\end{array}$ & (2001, p. 18) & $\begin{array}{l}\text { Generational } \\
\text { Poverty }\end{array}$ & $\begin{array}{c}\text { "Generational poverty is defined as being in poverty for two } \\
\text { generations or longer." }\end{array}$ \\
\hline Sachs & (2005) & $\begin{array}{l}\text { Extreme } \\
\text { Poverty }\end{array}$ & $\begin{array}{c}\text { "It includes all those poor people whose income is less } \$ 1 \text { a day. } \\
\text { Moreover, people living in extreme poverty do not have access to } \\
\text { clean water. They have no shelter, no proper health facilities, and } \\
\text { no basic education and are suffering with hunger." }\end{array}$ \\
\hline Sachs & (2005) & $\begin{array}{l}\text { Moderate } \\
\text { Poverty }\end{array}$ & $\begin{array}{l}\text { "It includes all those poor people whose income is } \$ 1 \text { to } \$ 2 \text { and } \\
\text { they do not have adequate access to the basic needs. Moreover, } \\
\text { people living in moderate poverty do not have enough wealth to } \\
\text { provide their children with better health and education facilities." }\end{array}$ \\
\hline Sachs & (2005) & $\begin{array}{l}\text { Relative } \\
\text { Poverty }\end{array}$ & $\begin{array}{c}\text { "It includes all those poor people whose household income is } \\
\text { below the barrier set by the nation based on other people's income } \\
\text { in same region. People living in this category have access to basic } \\
\text { education, health and all other entertainments but lag behind in } \\
\text { quality services." }\end{array}$ \\
\hline $\begin{array}{l}\text { Hussain, } \\
\text { Bhuiyan } \\
\text { and Bakar }\end{array}$ & $(2014$, p. 560$)$ & $\begin{array}{l}\text { Absolute } \\
\text { Poverty }\end{array}$ & $\begin{array}{c}\text { "Absolute poverty is explained as lack of resources to meet the } \\
\text { physical needs for survival." }\end{array}$ \\
\hline
\end{tabular}

Poverty can affects human beings psychologically, physically and morally. Blackwood and Lynch (1994) recognized "poor" on the basis of utilization and consumption of goods and utilization of services. Hence, Kareem (2015) described poverty as lack of basic goods and services, lack of productive and common resources. 


\subsection{Concept of Entrepreneurship}

This section presents further discussion on the concept of entrepreneurship.

\subsubsection{Entrepreneurship in Historical Perspective}

Entrepreneurship is one of the oldest human activities. This activity is focused on identifying new opportunities and using those opportunities in a new business venture for monetary gain (Landstrom, 2007). The first entrepreneurship activity was mentioned by a Greek philosopher Xenophon (approx., 430-354 B.C)

"So deep in their love of corn that receiving reports that it is abundant anywhere, merchants will voyage in quest of it: they will cross the Aegean, the Euxine, the Sicilian sea; and when they have got as much as possible, they carry it over sea, and they actually stow it in the very ship in which they sail themselves. And when they want money, they don't throw the corn away anywhere at haphazard, but they carry it to the place where they hear that corn is most valued and the people prize it the most highly, and deliver it to them there."

(Xenophon as cited in Oeconomicus, quoted in Karayiannis, 2003, p. 558)

Entrepreneurship is originally derived from a French word "Entrepreneur",celui qui entreprend quelque chose" (a person who is active and achieves something) (Landstrom, 2007, p. 8). This word has been a part of the French language since $12^{\text {th }}$ century and appeared in the "Dictionnaire de la Langue Francaise" for the first time in 1437 (Landstrom, 2007). In the medieval period of French history many French writers used this word in connection with military initiatives. Later on this term was referred to a person who is tough and ready to take risk in his own life and business. By the start of the $17^{\text {th }}$ century the risk taking element of one's personality became a hallmark of the entrepreneur. Only those individuals who involved themselves in a big construction projects, especially related to the army, which involved lots of planning, huge capital and managerial skill were called entrepreneur (Bettis \& Hitt, 1995). Later this term was extended to other public activities which involved technical and managerial skills to make those undertaking a success (Meyer \& Heppard, 2000). The frequent use of this word gave the concept of entrepreneurship.

In the Middle Ages, the economies of the most of European countries, especially France, Italy and Germany were dominated by agriculture and economic activities were governed and 
controlled by the feudal system. The role and scope of entrepreneur and entrepreneurship was hampered by the feudal system (Landstrom, 2007). During the middle ages, with the rise of cities the situation gradually started to change. A new economic class of merchants and traders began to emerge. By the end of the $18^{\text {th }}$ century the feudal system had largely disappeared and new legal and institutional frameworks emerged to support commerce and trade activities. This developed a breeding ground for entrepreneurship, stock companies and banking systems (Wennekers \& Thurik, 1999). New institutions and legal and political conditions encouraged business class to use innovative methods in their businesses to make them more profitable.

\subsubsection{Definitions of Entrepreneurship}

The term entrepreneurship is often loosely used for any business activity. In case of defining the central concept of entrepreneurship, it seems difficult in differentiating entrepreneurship from small medium businesses (Landstrom, 2007; Morris, 1998). Entrepreneurship has been defined by economists, social scientists and academicians in a different ways. The number of definitions found in various studies seems almost equal to the number of authors. For instance, Morris (1998) identified 77 definitions while sifting through research papers and business related books and Gartner (1988) found 99 definitions described by political leaders, business icons and academicians. These ambiguous definitions are considered a stumbling block in furthering the research on scientific ground.

Some example definitions abstracted by Landstrom (2007, p. 11) are shown in Table 2.5:

Table 2.5 Definitions of Entrepreneurship

\begin{tabular}{|l|l|}
\hline \multicolumn{1}{|c|}{ Author } & \multicolumn{1}{c|}{ Definition } \\
\hline Drucker (1985) & $\begin{array}{l}\text { "Entrepreneurship is an act of innovation that involves endowing existing resources with new } \\
\text { wealth-producing capacity." }\end{array}$ \\
\hline $\begin{array}{l}\text { Stevenson and } \\
\text { Gumpert (1985) }\end{array}$ & $\begin{array}{l}\text { "Entrepreneurship is a process by which individuals pursue and exploit opportunities irrespective } \\
\text { of the resources they currently control." }\end{array}$ \\
\hline Gartner (1988) & $\begin{array}{l}\text { "Entrepreneurship is a creation of organizations, the process by which new organizations come } \\
\text { into existence." }\end{array}$ \\
\hline Timmons (1997) & $\begin{array}{l}\text { "Entrepreneurship is a way of thinking, reasoning, and acting that is opportunity driven, holistic in } \\
\text { approach, and leadership balanced." }\end{array}$ \\
\hline Venkataraman (1997) & $\begin{array}{l}\text { "Entrepreneurship is about how, by whom, and with what consequences opportunities to bring } \\
\text { future goods and services into existence are discovered, created, and exploited." }\end{array}$ \\
\hline
\end{tabular}

An over view of various definitions will help to understand various characteristics stressed upon by the authors having different entrepreneurial approach. 
Drucker explained that, "The entrepreneur always searches for change, responds to it, and exploits it as an opportunity" (Drucker, 2014, p. 33). Hill and McGowan (1999) also investigated that entrepreneurship helps an individual or individuals to identify opportunities in the environment and utilize resources to generate profit from those opportunities. Timmons and Spinelli (2004) opined that entrepreneurship helps an individual or (individuals) to become creative within the environment and generate profit by exploiting the opportunities. Ogundele (2001) discussed that the concentration of the entrepreneurship is to examine the behavior of organizations, effective use of resources \& capabilities and the level of profit.

Coulter, in 2001, described entrepreneurship as a process where an individual uses his skills to identify the opportunities and use resources and innovation to create value and fulfill the needs of those opportunities. According to Kuratko and Hodgetts (2004, p. 30), "Entrepreneurship is a dynamic process of vision, change and creation." Similarly according to Adenutsi (2009, p. 5), "Entrepreneurship is defined as, the identification of venture or business opportunities and economic resources with the purpose of making a profit." This process will help an entrepreneur to develop a business with the objective of making a profit by utilizing the given situation and resources. In the process of entrepreneurship, an entrepreneur should focus on innovation, initiative, and imagination which will help him to create a regular cash flow in the long term. (Adenutsi, 2009)

When people discuss entrepreneurship they sometime combine together the concept of entrepreneurship, self-employment and small medium firms (SMEs). The research on entrepreneurship is focused on the questions "What is Entrepreneurship and How is entrepreneurship developed?" (Stevenson \& Jarillo, 2007). The answer to these questions give insight into the process that involves the functions, activities, opportunities and organizations of the business. According to Hisrich and Peters (1989), a business enterprise is a way of making something significant by dedicating the fundamental aptitudes, time and efforts to achieve profit and personal satisfaction. Entrepreneurship can help in the growth of the economic development positively and alleviate poverty by creating more jobs, allowing more people to become entrepreneur and improve the standard of life by providing the poor an access to the basic goods and services (Mead \& Liedholm, 1998). Furthermore, entrepreneurship plays an important role in the progress of the local industries and existing enterprises which will generate new jobs in the market. There are two ways through which entrepreneurship can help a person; Firstly it allows a 
person to consider entrepreneurship as an opportunity of self-employment; Secondly it allows a person to become an entrepreneur which can create more jobs for other people in the society (Bagheri \& Pihie, 2010).

\subsubsection{SMEs and Micro Businesses}

SMEs (including Micro businesses which means small shops etc.) have played a vital role in the creation of jobs. Both developed and developing countries have been using this approach for the development of their economy (Mohd, Chea, \& Juhary, 2010). Many countries have recognized Micro, Small and Medium Enterprise as a strategic tool to alleviate poverty and allow people to work for themselves.

\subsubsection{Social Entrepreneurship}

Social entrepreneurship has been defined as "using business activities by an individual for the benefit of society" (Austin, Stevenson, \& Wei-Skillern, 2006, p. 1). Social entrepreneurship is a process of utilizing the skills of the entrepreneur or an individual and resources of the area to overcome several problems faced by developed and developing countries. Social entrepreneurship helps to seek the solutions to the issues related to the social wellbeing of the society and collects the useful resources to satisfy needs of the people by improving living standard in that society (Santos, 2012).

\subsubsection{Self-employment vs. Small Businesses vs. Entrepreneurship}

Different observers consider self-employment, SME and entrepreneurship differently. For example, a broad definition of entrepreneurship includes self-employment or running small medium enterprises; whereas others argued more narrowly that entrepreneurship is the activity of risk taking individuals.

Self-employment is often seen a way to alleviate poverty. According to Kirzner (1979), self-employment opportunity has been a successful mechanism for a person to improve the standard of life while living in an area where there are no other employment opportunities or government support system. For example, a person living in rural areas does not have opportunities for jobs or any other source of income. In the villages there may be no electricity and less or no access to financial institutions such as bank. This person may start a business by selling the milk of cows, goat or by opening a small retail store. These sort of businesses are self-employment businesses. Self-employment activities are usually helpful to alleviate poverty for an individual 
person but it will likely not have much impact on the economic growth of the area in particular and economic growth of the country. Most of the time the proportion of profit is too low to play any role in the development of the economy (Collins, Smith, \& Hannon, 2006). With the help of facilitators such as government support programs and other financial institutions, some of these small businesses can be turned into a large entrepreneurial businesses which will create more jobs and can generate enough profit to have positive impact on economy (Landes, 1998; McCloskey, 2010).

\subsubsection{Entrepreneurship through the Lens of Economics -- The Market View}

Economists were amongst the first to examine the concept of entrepreneurship in a scientific way. Richard Cantillon (approx. 1680-1734) in his posthumously published book "Essai Sur la Nature $d u$ Commerce en Ge'ne'ral" was a banker who analyzed the role of entrepreneur from an economist standpoint (Cantillon, 1756). He assumes that entrepreneur must understand the demand and supply mechanism of the market and create opportunities to earn profit by buying cheaply and selling at a higher price without disturbing the equilibrium of market. Jeremy Bentham (1748-1832) was another economist who recognized the role of entrepreneur in the society but for him the entrepreneur was a person who undertook certain projects on a contractual basis (Landstrom, 2007). Jean Baptiste Say (1767-1832) shed light on the role of entrepreneur in his works, "Traite' d'economie politique (1803/1964)" and "Cours complet d' e'conomie politique(1828)" (Say, 2008). Defining entrepreneurship as a combination of various production factors into an organic whole. He describes the entrepreneur as a "broker" who manages factors governing production with the sole aim of producing goods and earn money. According to Say, entrepreneur was a coordinator managing the means of production and he does all the activities at his own risk (Landstrom, 2007; Say, 2008).

By the end of the nineteenth century the focus of economic science shifted from macroeconomics to micro economics. This new outlook gave rise to the theory of equilibrium in which every individual was either producers or consumers and the basic purpose of economics was to strike a balance between them. Alfred Marshall (1842-1924) was a prominent economist who in his work Principles of Economics (1890) discuss the role of entrepreneur as a multifaceted capitalist (Marshall, 1890). In his more institutional work he terms entrepreneurs as "the best educators of initiative and versatility, which are the chief sources of industrial progress." (Marshall, 1919, p. 249) 
Researchers from Germany and Austria also contributed toward the evolution of entrepreneurship theory. Von Thunen (1783-1850) recognized difference between entrepreneurship and management and considered the entrepreneur as an innovator and a risk taker (Landstrom, 2007). The Austrian economist Menger (1840-1921) considered an entrepreneur a person who transformed goods on various stages of production chain investing time, volatility and risk (Menger, 1981). The American Economist Frank Knight (1885-1972) discussed the role of entrepreneurship and an entrepreneur in his thesis Risk, Uncertainty and Profit (1916) (F. Knight, 1916). He says that an entrepreneur makes profit by taking risks while making decisions about uncertain future. The profit of an entrepreneur depend upon his level and intensity of activity, entrepreneurial competence and his capacity to deal with unpredictability of future.

Joseph A. Schumpeter, a renowned economist and social scientist made the entrepreneur a central figure in his theory. He claimed that entrepreneurship need special types of personalities which has a mixture of rational utilitarian elements in addition to emotional elements (Landstrom, 2007). In his seminal theory of "Creative Destruction", positive economic development lead to a crisis. When an entrepreneur enters into a market and faces large firms and suppliers especially with innovative views, he finds himself helpless as these firms expand their economic activities and destroys a market structure. Schumpeter views on entrepreneurship continued to change with the passage of time (Schumpeter, 1934, 1942; Schumpeter \& Backhaus, 2003; Schumpeter \& Perlman, 1954). Table 2.6 shows different entrepreneurial functions proposed by scholars.

Table 2.6 Five Entrepreneurial Functions

\begin{tabular}{|l|l|}
\hline \multicolumn{1}{|c|}{ Entrepreneurial Functions } & \multicolumn{1}{c|}{ Source } \\
\hline Entrepreneur as a risk-manager & (Cantillon, 1756; F. Knight, 1916; Say, 2008) \\
\hline Entrepreneur as an innovator & (Baumol, 1993; Dahmén, 1970; Schumpeter, 1934) \\
\hline Entrepreneur as a manager of available resources & (Casson, 1982; Say, 2008) \\
\hline Entrepreneur as an opportunity seeker & (Kirzner, 1973; Mises, 1952) \\
\hline Entrepreneur as a capitalist & (Marshall, 1890; Smith \& McCulloch, 1838) \\
\hline
\end{tabular}

Source: (Landstrom, 2007, p. 13)

\subsubsection{Entrepreneurship and the Social Sciences -- Looking at the Individuals}

Davidsson (2001; 2003) identified entrepreneurship as a social phenomenon. He looks at entrepreneurship as a function of society that will affect the market in a positive way. In society, the entrepreneurship concept is often attached to a successful outcome. Usually this outcome is 
considered at two levels: venture and society. When ventures are successful, they produce utility in the society in an unproblematic way. These ventures may inspire other actors in the market which will enhance the entrepreneurial activity. This means that entrepreneurship should drive the market process in a way which will alleviate poverty.

Behavioral science has focused on the entrepreneurs as an individual and have tried to answer the questions that "who is the entrepreneur" and "why do they act" (Stevenson \& Jarillo, 2007). Table 2.7 shows different definitions of entrepreneurs given by scholars.

Table 2.7 Definitions of Entrepreneurs

\begin{tabular}{|c|c|c|}
\hline Author & Definition & Source \\
\hline Schumpeter (1934) & $\begin{array}{l}\text { "The entrepreneur is an innovator introducing new } \\
\text { combinations of resources." }\end{array}$ & (Landstrom, 2007, p. 16) \\
\hline Knight (1942) & $\begin{array}{l}\text { "An entrepreneur is an owner of a company who receives profit } \\
\text { and one who takes a risk." }\end{array}$ & $\begin{array}{l}\text { (Chowdhury, Desai, \& } \\
\text { Audretsch, 2017, p. 25) }\end{array}$ \\
\hline Cole (1959) & $\begin{array}{l}\text { "... An individual or group of individuals who initiate, maintain } \\
\text { or expand a profit-oriented business unit for production or } \\
\text { distribution of economic goods and services." }\end{array}$ & (Landstrom, 2007, p. 16) \\
\hline Kirzner (1973) & $\begin{array}{l}\text { "An entrepreneur is someone who facilitates adjustment to } \\
\text { change by spotting opportunities for profitable arbitrage (and } \\
\text { "disequilibrium" situation in the market." }\end{array}$ & $\begin{array}{l}\text { (Currie-Alder, Kanbur, } \\
\text { Malone, \& Medhora, 2014a, } \\
\text { p. 25) }\end{array}$ \\
\hline Shapero (1975) & $\begin{array}{l}\text { "The entrepreneur takes initiatives, organizes social and } \\
\text { economic mechanisms and accepts the risk of failure." }\end{array}$ & (Landstrom, 2007, p. 16) \\
\hline Kanbur (1979) & $\begin{array}{l}\text { "An entrepreneur is the one who "manages the production } \\
\text { function" by paying workers' wages (which are more certain } \\
\text { than profits) and shouldering the risks and uncertainties of } \\
\text { production." }\end{array}$ & $\begin{array}{l}\text { (Currie-Alder, Kanbur, } \\
\text { Malone, \& Medhora, 2014a, } \\
\text { p. 25) }\end{array}$ \\
\hline Brockhaus (1980) & "A major owner and manager of a business venture." & (Landstrom, 2007, p. 16) \\
\hline Kirzner (1997) & $\begin{array}{l}\text { "Entrepreneur is the one who is alert to perceiving } \\
\text { opportunities." }\end{array}$ & (Choy \& Chong, 1986, p. 3) \\
\hline Falkäng and Alberti (2000) & $\begin{array}{l}\text { "People with entrepreneurial spirit (individuals who wish to } \\
\text { kindle an entrepreneurial spirit within themselves)." }\end{array}$ & $\begin{array}{l}\text { (Falkäng \& Alberti, 2000, p. } \\
\text { 103) }\end{array}$ \\
\hline
\end{tabular}

The definitions in Table 2.7 show that the entrepreneur is not a small business owner. The Entrepreneur has specials traits and characteristics which persuade him or her to have a total commitments to make his enterprise successful. Four things can help entrepreneurs in entrepreneurial activities such as creativity, eager to learn, competence and self-confidence (Landstrom, 2007, p. 16). 
The following Table 2.8 gives insight into the various school of thoughts about the characteristics of a successful entrepreneurship.

Table 2.8 Different School of thoughts about Entrepreneurship \& Entrepreneurs

\begin{tabular}{|l|l|}
\hline \multicolumn{1}{|c|}{ School of Thoughts } & \multicolumn{1}{c|}{ Characteristics } \\
\hline "Great person" school & $\begin{array}{l}\text { "The entrepreneur has an intuitive ability- a sixth sense- and inborn traits and } \\
\text { instincts." }\end{array}$ \\
\hline Psychological characteristics school & "Entrepreneurs are driven by unique values, attitudes, and needs." \\
\hline Classical School & $\begin{array}{l}\text { "The central characteristics of entrepreneurial behavior is innovation, and the } \\
\text { entrepreneur is therefore creative and discovers new opportunities." }\end{array}$ \\
\hline Management School & $\begin{array}{l}\text { "Entrepreneurs are organizers of an economic venture; entrepreneurs are people who } \\
\text { organize, own, manage and assume the risk." }\end{array}$ \\
\hline Leadership School & $\begin{array}{l}\text { "Entrepreneurs are leaders of people; entrepreneurs have the ability to adapt their } \\
\text { style to the needs of the people." } \\
\text { "Entrepreneurship skills can be useful in complex organizations; intrapreneurs who } \\
\text { develop independent units to create markets and expand services." }\end{array}$ \\
\hline Intrapreneurship School
\end{tabular}

Source: (Cunningham \& Lischeron, 1991, p. 47)

\subsubsection{Most Recent Prospective -- Entrepreneurship as a Process}

Before starting a business, a person need to determine how he or she can identify opportunities and implement for financial benefits. Entrepreneurship is a process in which people uses different techniques and models to increase the chances of their startup to be successful. Moreover, taking process view allows people to develop a better understandings of the market.

Two of the most current techniques which the entrepreneurs commonly use are Lean Launch Pad and Business Model Canvas. Lean Launch Pad is considered to be an essential practice in the process of entrepreneurship. It help entrepreneurs to develop their business plan by considering the factors which can affect their startups. The three main elements of lean startups are classroom learning, practical/experimental knowledge and team-based learning (Eisenmann, Ries, \& Dillard, 2012). Alexander Osterwalder, in his extremely popular book proposes a Business Canvas Model which offers nine steps to a person which will help him or her to make an effective business startup. Those nine steps of business canvas model are key partners, key activities, key resources, value propositions, customer relationships, customer segments, channels, cost structure, and revenue streams (Osterwalder \& Pigneur, 2010). 


\subsection{Relationship between Entrepreneurial Activity and Poverty}

According to Spencer and Gómez (2004) and Wennekers and Thurik (1999), there are so many variables which have cause and effect relationship with both entrepreneurial activity and economic development. Similarly, at country level it is difficult to develop a model which can determine the causality between the entrepreneurial activity and economic development. Minniti (2013) explained that usually there are two types of studies that have been done on entrepreneurial activity and economic development. Some studies have illustrated that better entrepreneurial activity will enhance economic growth (Acs \& Storey, 2004; Audretsch \& Keilbach, 2004; Karlsson, Friis, \& Paulsson, 2004; Schramm, 2004; Wennekers \& Thurik, 1999) whereas other studies illustrated that better economic development will increase the level of entrepreneurial activity (Carree, Stel, Thurik, \& Wennekers, 2007; Grilo \& Irigoyen, 2006; Hessels, Gelderen, \& Thurik, 2008). Moreover, in developed countries there is a significant impact of entrepreneurial activity on the economic development. (Acs \& Amorós, 2008; Stel, Carree, \& Thurik, 2005; Tang \& Koveos, 2004; Wennekers, Wennekers, Thurik, \& Reynolds, 2005)

Minniti (2013) studied the relationship between entrepreneurial activity and poverty. Usually in developing countries, poor people with less income or no income will shift from small labor jobs towards self-employment where they can improve their standard of life. According to Naudé (2010), there are more entrepreneurs in low-income or poor countries. As S. Shane stated, "... if you want to find countries where there are a lot of entrepreneurs, go to Africa or South America" (S. Shane, 2009, p. 143). Similarly, Banerjee and Duflo (2007, p. 151) discussed that "All over the world, a substantial fraction of the poor act as entrepreneurs in the sense of raising capital, carrying out investment, and being the full residual claimants for the resulting earnings."

According to Zoltan J. Acs and Amorós (2008), in developing countries there is positive impact of entrepreneurial activity on economic growth because people were not able to find suitable jobs which motivated them towards necessity entrepreneurship (Naudé, 2007; Singer, 2006). Reynolds et al. (2005), "cannot find a suitable role in the world of work" and "creating a

new business is their best available option." (Reynolds et al., 2005, p. 217). Although there are many researchers who claimed that high level of entrepreneurial activities is because people are more inclined towards opportunity entrepreneurship. (Bosma, Acs, Autio, \& Coduras, 2008; Carter, Gartner, Shaver, \& Gatewood, 2003; Feldman \& Bolino, 2000; Kolvereid, 1996). 
According to Powell (2008), Bangladesh (developing or low-income per capita country) is utilizing the entrepreneurial activities to improve the standard of life and alleviate poverty.

Today, in both developed and developing countries, governments having special programs in which a person with a proper business plan can have access to finance. In Pakistan, International Finance Corporation (IFC) is helping people to establish Small and Medium Enterprises (SME) (World Bank Group, 2011). Similarly, in developed countries, such as Canada, the government has different grants and financing programs to support the young and promising entrepreneurs. (Government of Canada, 2014).

Audretsch and Keilbach (2004) believe that entrepreneurship is one of the best way to promote the economy of the country. Entrepreneurship will allow people to utilize available resources and skills with their maximum capacity to convert the available opportunity into financial benefit. This financial benefit is a result of entrepreneurial activity. Entrepreneurial activity will motivate people to start their enterprises or expand the existing one's which will create more jobs in the market (Bruton, Ahlstrom, \& Si, 2015; Lerner, 2009; Lu, Au, Peng, \& Xu, 2013).

Acs (2006) examined the role of entrepreneurial activities in both developed (Japan, Sweden and Germany) countries and developing (Uganda, Peru and Ecuador) countries. To measure entrepreneurial activities, Acs collected the data from Global Entrepreneurship Monitor (GEM) on both necessity entrepreneurship and opportunity entrepreneurship. The results showed that people are more inclined towards opportunity entrepreneurship in developing countries and there is a positive relationship between opportunity entrepreneurship and economic growth.

And in developed countries there is a positive relationship between necessity entrepreneurship and economic growth. This shows that people living in developing countries are pursuing opportunity entrepreneurship; while people living in developed countries are pursuing necessity entrepreneurship to enhance entrepreneurial activities (Acs, Arenius, \& Minniti, 2004). The development in entrepreneurial activities will help a nation to grease the wheel of economy and alleviate poverty.

According to Acs (2006), countries with high level of per capita income relatively have high level of entrepreneurial activity. U.S. has high level of per capita income and that is why there is high level of entrepreneurial activity. 


\subsubsection{Linking Entrepreneurship and Poverty Alleviation}

Several studies have been done by scholars to investigate the impact of entrepreneurship in creating employment and reducing poverty. Scholars in other business fields such as Economics and Management have also tried to explore different approaches and identify their relationship with poverty alleviation (Bruton et al., 2013). Entrepreneurship is a technique which can help the countries to decrease the poverty (M. D. Hussain et al., 2014).

Entrepreneurship can be seen as a mechanism which allows countries to create new jobs, reduce poverty, attract the foreign investors, bring new innovation to grow the productivity and competition between the existing businesses (Baron \& Shane, 2007). There are three different categories of entrepreneurship i.e. Social Entrepreneurship, Micro, Small and Medium Enterprise and Entrepreneurship Facilitators (Government, Incubators, and Financial Institutions). Some evidence showed that there is a positive relationship between entrepreneurship and poverty. From the many existing studies, 11 papers from 1991 till 2016 have been selected to explain the gap between the evidences of those researches. Those are discussed below:

\subsubsection{The Economic Role of Startups and SME's in Alleviating Poverty}

Abdullah (1999) examined government supported programs in Penang, Malaysia. He collected data on 185 Small Medium Enterprises (SMEs) by using the survey method. He found that lack of adequate knowledge had caused people to have limited access to these government programs. This is because of ill-conceived policies of the Malaysian government and policy makers.

Okpara in 2011 identified the factors which slow down the growth and life span of SMEs in Nigeria. He used a survey of 211 SMEs registered in National Bank of Nigeria. The author suggested that the SMEs failing rate is higher in developing countries than in developed countries. The author explained internal and external factors into four groups (administrative, exogenous, strategic and operating) which effect SMEs to survive in Nigeria, concluding that government and policy makers should focus on seven factors (lack of financial access, less demand of product in market, less profit, high corruption level, lack of work experience, poor administration and weak infrastructure) to enhance the growth and increase the chances of survival of small and medium businesses in Nigeria (Okpara, 2011). 
Table 2.9 Discussion of Economic Role of Startups and SMEs

\begin{tabular}{|l|l|c|c|c|}
\hline No. & \multicolumn{1}{|c|}{ Authors } & SME & Governance Factor & Economic Indicator \\
\hline 1. & Abdullah (1999) & $\mathrm{X}$ & $\mathrm{X}$ & \\
\hline 2. & Okpara (2011) & $\mathrm{X}$ & & \\
\hline
\end{tabular}

The studies discussed above helped in identify the gap that these researchers have not used any economic indicator which is being affected with the development small medium enterprises. When more businesses are registered or expanding, it will enhance economic growth which will generate more jobs in market and allow people to improve their standard of life.

\subsubsection{The Effects of Education on Entrepreneurial Development}

Goldsmith and Kerr (1991) took a sample of a class with 34 business students and applied a statistical method to investigate Kirton's Adaption-Innovation (KAI) theory which explains different style of critical thinking, innovation and creativity in entrepreneurship. It was observed that there was a difference between the knowledge, creativity level and decision making skills of those students before and after the start of the semester. They found that as compared to the general people, these students were having high KAI score at the end of the semester.

Kolvereid and Moen (1997) studied how business education (a major in entrepreneurship) can develop the personality traits of an individual. The author compared graduate students of major in entrepreneurship with the graduate students of major in different fields to determine which field developed better entrepreneurial behavior in students. They studied six business schools in five countries teaching entrepreneurship and concluded that there is a positive relationship between education in entrepreneurship and entrepreneurial behaviour.

Wang and Wong (2004) analyzed the behavior of undergraduate students towards starting or become a part of business enterprise. The study was done in Singapore, where they collected the data of undergraduate students from different universities. They found that to start a new business there are some factors which directly influence a person (Family background, Educational and training level and Gender). Furthermore, they found that the level of passion and enthusiasm to start a new business and becoming entrepreneur are present in Singapore mostly in male students. 
Ogundele, Akingbade, and Akinlabi (2012) discussed the effectiveness of entrepreneurship training and education in enhancing the skill of entrepreneurs so that they can survive in business world. They classified three skills (business management, technical skills and personal entrepreneurial skills) of an entrepreneurs. They did a survey of 250 entrepreneurs in five divisions of Nigeria. They concluded that there was a positive relationship between youth empowerment and technical skills. Entrepreneurship training helps to create productive environment to overcome future challenges.

Table 2.10 Discussion about the Effect of Education on Entrepreneurial Development

\begin{tabular}{|l|l|c|c|c|}
\hline $\begin{array}{l}\text { N } \\
\text { o. }\end{array}$ & \multicolumn{1}{|c|}{ Authors } & Education & Entrepreneurial Behavior & Entrepreneurial Skills \\
\hline 1. & R. E. Goldsmith and Kerr (1991) & $\mathrm{X}$ & & \\
\hline 2. & Kolvereid and Moen (1997) & $\mathrm{X}$ & $\mathrm{X}$ & \\
\hline 3. & Wang and Wong (2004) & $\mathrm{X}$ & & \\
\hline 4. & $\begin{array}{l}\text { Ogundele, Akingbade, and Akinlabi } \\
\text { (2012) }\end{array}$ & $\mathrm{X}$ & & $\mathrm{X}$ \\
\hline
\end{tabular}

The studies discussed above helped in identify the gap that these researchers have discussed the role of entrepreneurship education in the development of entrepreneurial skills in entrepreneurs. But they have not discussed the role of tertiary education in human development.

\subsubsection{Discussion of Measures to Evaluate the Correlation between Entrepreneurial Activity \& Poverty Alleviation}

Meyer and Birdsall (2012) investigated whether an increase in the economic growth will help a majority of household to come out of poverty. They classified the middle class into 'seeker' and 'striver'. On the basis of the National Sample Survey (data of 70 million people) by the Indian Government in 2009-2010; they identified two different per capita incomes per month, one for urban middle class and other for rural middle class. They converted the rupee intro International PPP dollar so that a standard price of per capita can be calculated. After their results they concluded that there should be one poverty line for the whole country. Government should help people to come out of their poverty and secure their middle class in terms of material benefits so that the middle class should have a chance to enter into rich upper class. 
Yassin and Abdel (2013) emphasized the importance of entrepreneurship development in the economic growth of Somalia. They used a sample date of 80 participants in one region of Somalia. They used correlation research design to determine the relationship of entrepreneurship and poverty reduction. They concluded that there was a weak relationship between entrepreneurship development and poverty. Also entrepreneurship promote new market by contributing into social wealth which leads to poverty reduction.

Bruton, Ketchen, and Ireland (2013) examined the role of entrepreneurship in helping those people who are living in poverty. They explained that entrepreneurship can overcome the barriers set by the institutions, so that a market-based approach can be used for improving the lot of the poor. In this paper the authors compared the research and impact of three different fields (Management, Economics and Entrepreneurship) on poverty. Their findings suggest that entrepreneurship can provide long lasting solutions to the problem of poverty more than economics and management.

Steven Si and Xuebao Yu (2015) illustrated the role of business in creating opportunities for poor people. They describes the importance of innovation and entrepreneurship in reducing poverty in Yiwu, China. They determined that there are some key factors which are used by peasants that contributed in reducing poverty. These factors are "feathers-for-candy stage, the roadside-stall stage and the small-commodity-market stage" (Si et al., 2015, p. 124). Those key factors were divided into three categories which contributed in reducing poverty in Yiwu. They concluded that the struggle of peasant in using these three categories helped them in creating new jobs and development in poverty alleviation.

Nistotskaya and Cingolani (2016) illustrated the role of government regulation in the development of entrepreneurial activities. They concluded that government regulatory bodies can play a vital role in the development of entrepreneurial activities. Quality of bureaucracy and its impact on corruption is very important to determine the ratio of number of business registered or business entry in a nation. There is a direct link between the quality of bureaucracy and the implementation of rules and regulation in a society. They concluded that if the bureaucracy is honest and bureaucratic hurdles are minimum, the level of corruption will be low, which will facilitate a person in the process of starting or registering a new business. Moreover, good governance will allow people to have better health and education facilities. 
The above discussion has also illustrated the gaps or the barriers in the existing research about the relationship between entrepreneurship and poverty alleviation. These researchers have identified the determinants of entrepreneurship which help a person to become an entrepreneur and create an ease for a person in registering property, having access to finance, dealing with construction permits, and trading across the border in case of developed, developing and underdeveloped countries. This research project focuses on the role of Entrepreneurship Facilitators (Government, Incubators, and Financial Institutions) in developing a new mechanism of entrepreneurship. That can facilitate the process of alleviation the poverty. 


\section{CHAPTER 3}

\section{Determining the Influence of Entrepreneurial Activity on Poverty Alleviation}

\subsection{Introduction}

To determine the impact of entrepreneurial activity on poverty, there is a need to establish an appropriate dependent variable to measure poverty and to investigate its relationship with entrepreneurial activity. In many cases, Gross National Income (GNI) is proposed as a measure of poverty (Todaro \& Smith, 2003).

However, GNI has some weaknesses and is not a good indicator to measure the standard of life, which plays an important role in the development of entrepreneurial activity. Capelli and Vaggi (2013) argued that Gross National Income (GNI) is not a good indicator to measure the standard of living. For example, in the case of developing countries, it does not recognize foreign remittances which is one of the main impact on the growth of economy. Foreign remittances has a significant impact on the purchasing power of the people living in developing countries.

Various ways have been proposed to measure links between entrepreneurship activity and poverty but limited work has been done to quantify this relationship. Moreover, one of those measures, Total Entrepreneurial Activity (TEA), often used by some scholars to measure entrepreneurial activity is opinion survey data and it is not an actual behavior of an entrepreneur. Moreover, some other measures such as Human Poverty Index (HPI), Legatum Prosperity Index (LPI) and Global Multidimensional Poverty Index (GMPI) have data only from 2010 onwards, but in this study the data of all variables used was available from 2005 to 2016, thus providing a longer time series for analysis.

An alternative measure that potentially offers a better fit is the Human Development Index (HDI). Human Development Index is comprised of education, health and standard of life which makes it a better choice to be used as a proxy to measure poverty. 


\subsection{Human Development Index (HDI)}

According to the United Nation Development Programme (UNDP, 2018), the human development index is an aggregated number using the data of,

- Long and healthy life (life expectancy at birth)

- Knowledge (expected years of education)

- A decent standard of living (GNI per capita PPP \$)

The UNDP collected worldwide data and published an annual report on HDI (UNDP, 2018). According to Sen (2000), a person having both better income and capability can improve the standard of life. So, there is a correlation between person's capability and level of income. Sen (2000) illustrated that better health and education will help people to overcome poverty and enjoy better quality of life.

The concept of human development includes the endeavors of government officials to improve the health services, social security, education and standard of living. Such efforts can create an environment for people to maximize their potential and have a superior and innovative life (Monsef, Sameti, \& Mojahednia, 2011). Moreover, human development is not just about the expansion of a nation's economy. It is about allowing people to learn new skills, gain knowledge, get required resources to improve their life style and enjoy healthy life. Better health will allow people to increase their capacity to accomplish their goals and improve the standard of their life, whereas education will help people to learn new skills and knowledge and allow them to exploit opportunities for profit.

The UNDP methodology identified four types of economies. The countries have been segmented on the basis of their HDI value.

- High-Income Countries (a value of 0.800 and above)

- High Medium-Income Countries (0.700 - 0.799)

- $\quad$ Medium-Income Countries $(0.550-0.699)$

- Low-Income Countries (Below 0.550)

According to Todaro and Smith (2003), high-income countries have high HDI. Because high-income level will allow people to have better life, education and health. Similarly high level 
income brings productivity in a country which raises the economic growth. According to Georgiou (2009a), entrepreneurial activities such as trade openness, services in hospitals, economic growth and education can improve HDI.

\subsection{Entrepreneurship Facilitators and their role in alleviating poverty}

The institutions who facilitate and motivate entrepreneurs in the process of starting, expanding or running businesses are known as entrepreneurship facilitators.

\subsubsection{Entrepreneurship facilitators}

Entrepreneurship facilitators include government, incubators, and financial institutions which help an individual to become an entrepreneur and create jobs for others (Bruton et al., 2013). Also, the authors discussed the role of entrepreneurship facilitators as institutions which are responsible to seek the solutions of poverty and enhance economic development (Carland, Hoy, Boulton, \& Carland, 1984). Entrepreneurship facilitators can play a vital role in creating a suitable environment for a person to become an entrepreneur.

\subsubsection{Governance Factors}

Governance Factor includes two main factors (regulation quality and corruption level) which play a vital role in the development of entrepreneurial activity in a country. Government regulatory bodies can play a vital role in the development of entrepreneurial activities (Nistotskaya \& Cingolani, 2016). The quality of bureaucracy and its impact on corruption is very important to determine the ratio of number of business registered or business entry in a nation (Nistotskaya $\&$ Cingolani, 2016). There is a direct link between the quality of bureaucracy and the implementations of rules and regulation in a society. If the bureaucracy is honest and bureaucratic hurdles are minimum, the level of corruption will be low which will facilitate a person in the process of starting or registering a new business.

\subsubsection{Regulation Quality}

Good governance can allow people to have better health and education facilities (La Porta, Lopezde-Silanes, Shleifer, \& Vishny, 1999; Rothstein \& Teorell, 2008; United Nations, 2000; World Bank, 1997). When a country has good governance and less corruption, more businesses will likely be registered. Nistotskaya and Cingolani (2016) also examined the impact of quality of governance and corruption level on number of business registered in both developed and developing countries by collecting data from Organisation for Economic Co-operation and Development and World 
Bank. The results showed that most developed countries have a good quality of governance and low levels of corruption. Thus the rate of businesses registered in developed countries is higher than the rate of businesses registered in developing countries. For example, the results of 2012 for both New Zealand (developed country) and Pakistan (developing country) showed that the rate of number of business registered in New Zealand was 15.7 per 1,000 working-age population, whereas the rate of number of business registered in Pakistan was 0.04 per 1,000 working-age population. So the role of good governance and low corruption is important in motivating people to start a business (Aidis, Estrin, \& Mickiewicz, 2008; Bjørnskov \& Foss, 2010; Klapper, Laeven, \& Rajan, 2006; Nistotskaya \& Cingolani, 2016; Nyström, 2008; Stenholm et al., 2013). Economic growth will likely take place because of higher rates of businesses registered and good governance. Acemoglu and Robinson (2013) said, "encouraged participation by the great mass of people in economic activities that make the best use of their talent and skills" by providing "a level playing field that gives them the opportunity to do so" (Acemoglu \& Robinson, 2013, p. 74, 76).

To respond to poverty a number of authors suggested that the nation must take steps to spur their economic growth. Various steps can be taken to improve the quality of human capital such as training, workshops and education (Claessens \& Laeven, 2004; Cohen \& Soto, 2007; Lucas, 1988; Romer, 1990; Yunus, 2007). Education and training will help people to learn new knowledge and skills which help them to improve the quality of life of their masses (Davidsson \& Honig, 2003; Minniti \& Lévesque, 2010). Similarly, by improving regulatory laws, governments can ensure property rights which will facilitate entrepreneurs and motivate them to start new businesses or expand their existing businesses (Cohen \& Soto, 2007). Such practices have been seen in developing countries where governments have been focusing on improving their fiscal and regulatory policies which protect the rights of the business community and the public at large. For example, an easy access to finances will motivate people to start new enterprises and this tool has been proved effective for the development of economy. Such steps on the part of governments can enhance entrepreneurial activities (Yunus, 2007). Such initiatives from government will help impoverished households to get rid of extreme poverty. According to Alvarez and Barney (2014), entrepreneurship have mixed financial impact on poverty alleviation.

Government must create a suitable business environment which entrepreneurs are seeking to start or expand their existing activities. Better economic condition will attract entrepreneurs 
from across borders to start new enterprises and create more jobs which help to reduce poverty in a society (Alvarez, Barney, \& Anderson, 2012).

If a government has unnecessary regulations and those regulations are creating hurdles for people in starting a business such as procedures to register business, approval from provincial or federal administrations, high taxes, access to finance etc. than the role of corruption in that nation may be supportive in enhancing the entrepreneurial activities. As Leff stated, "If the government has erred in its decision, the course made possible by corruption may well be the better one." (Leff, 1964, p. 11).

\subsubsection{Impact of Corruption on Entrepreneurial Activities}

Corruption is a major factor that influences entrepreneurial activity. Because of bad governance and high levels of corruption, most people either don't operate their businesses or they operate in an illegal way where they don't pay taxes or fulfill the required procedure of registering their business (Friedman, Johnson, Kaufmann, \& Zoido-Lobaton, 2000; Johnson, Kaufmann, \& ZoidoLobatón, 1998; Klapper, Raphael, \& Mauro F., 2010). Low corruption level and better government regulations can motivate people to start a business or register a business, easy access to finance, political stability and better economic policies. (Jovanovic, 1982; Rodrik, Subramanian, \& Trebbi, 2004).

In developing countries, the major obstacle that promising entrepreneur faces in the process of starting their own business is registering a business, property and fulfilling the legal obligations. Developing countries are more likely to have corrupt practices. For example, the level of corruption in some rural areas of Pakistan put barriers in the way for a person who wants to become an entrepreneur (GAN Business Anti-Corruption, 2017). According to GAN, most people believed that the local government officials are corrupt. So in the process of registering and fulfilling the obligations to start a business, a person has to wait for longer period of time. The more time a person is needed to register a business and creating value from that business, the more time is taken to create employment and enhance economic growth.

In developed countries the level of corruption is very low (Nistotskaya \& Cingolani, 2016). According to Mauro in 1995, with increased level of corruption, the fewer people will make investment in the businesses which will lower the economic growth of that country. So, in developed countries, there is a minimum level of corruption, and there are proper channels that 
facilitate the initiation of business and simplified process for registering a business. So, as compared to developing countries, the system in developed countries is transparent flexible and supportive towards the people in their process of registering a new business (World Bank, 2016a).

Dreher and Gassebner (2007) examined the role of corruption while implementing rules and regulations on entrepreneurial activities but in the countries with tough business regulations and bureaucratic hurdles, corruption works as a positive tool to bypass all this and start a new business. By doing an empirical analysis on 43 countries from 2003-2005, Dreher and Gassebner (2007) concluded that corruption usually has negative impact on entrepreneurial activities. If the performance of country's institution is quick and cumbersome force then implementation of regulations can enhance the entrepreneurial activities and the impact of corruption will be less in the start of entrepreneurial activities.

The level of corruption changes in both developed and developing countries based on the quality of governance (Avnimelech, Zelekha, \& Sharabi, 2014). Similarly, in some countries corporate corruption demotivates young entrepreneurs by creating barriers of entry, promoting the monopoly of the existing firms and unnecessary rise in the cut throat competitions. Corruption influences the scale of benefit which a nation or society is expecting from entrepreneurial activities. (Baumol, 1996)

Reynolds et al. (2005) examined 74 countries by collecting data from Global Entrepreneurship Monitor (GEM) and performed longitudinal data analysis. Reynolds et al. (2005) concluded that export oriented entrepreneurs will increase if a country has low corruption level. Similarly, Anokhin and Schulze (2009) examined 64 countries by collecting data from Global Entrepreneurship Monitor (GEM) and performed longitudinal data analysis. Anokhin and Schulze (2009) concluded that there is a significant negative relationship between corruption and entrepreneurial activity. Moreover, Gholami and Firozjaii (2012) collected data of 45 countries from Global Entrepreneurship Monitor (GEM) and performed panel regression. Gholami and Firozjaii (2012) also concluded that the level of corruption can affect entrepreneurship.

Effective regulations and low level of corruption can increase entrepreneurial activities and also contribute to improve the standard of life for people in a country (Guasch \& Hahn, 1999; Jalilian, Kirkpatrick, \& Parker, 2007). 


\subsubsection{Defining Entrepreneurship Facilitators}

Better government policies, incubators, and financial Institutions can act as facilitators for a person to become a successful entrepreneur. Moreover, these can also improve the standard of life, smooth the economic cycle, increase employment which could reduce poverty (Grant, Padmanaban, \& Kebbi, 2018; Kareem, 2015; Mitra et al., 2011; Okpara, 2011; Yassin \& Abdel, 2013).

Acumen and motivation are internal factors which play a pivotal role in motivating a person to become an entrepreneur ; however, finances, skills, capacity, and business-friendly environment are very crucial external factors in making the business a success (World Bank, 2016a). This study identifies the impact of external factors/entrepreneurship facilitators in developing a mechanism and strengthening entrepreneurship by encouraging innovative business ideas, making easy availability of funds, providing effective business training, improving the capacity of entrepreneur, making easy for people to deal with construction permits, registering property procedures, protecting the minor investors and ensuring business-friendly environment. Analyzing the role of government, incubators, and financial institutions as facilitators will impetus the process of entrepreneurship (Okpara, 2011).

Developed countries tend to have a very business friendly finance-support system in shapes of soft loans, grants and excellent business conducive environment for people to become an entrepreneur as compared to developing countries where people face liquidity shortage problem along with cumbersome bureaucratic procedures (D. Chen \& Mintz, 2005).

\subsubsection{Role of Entrepreneurship Facilitators}

One of the main role of entrepreneurship facilitators, such as Government, Incubators, and Financial Institutions, is to help people living in poverty to gain new knowledge and adapt new skills to establish novel goods and services (Mitra et al., 2011). Also, it can allow them to mobilize the main factors such as technology, labor and capital which can enhance the economy of the country. Entrepreneurship facilitators can help the country to generate employment by developing skills of people to overcome obstacles in their ways to have new start-up ventures or business activities (Yassin \& Abdel, 2013). This can allow people living in poverty to have selfemployment or create jobs for others. It means a single person can overcome poverty through selfemployment. Further, an entrepreneur can create more jobs and allow more people to overcome 
poverty. So the poverty levels of a country should decrease with the increase of the number of entrepreneurs (Bruton et al., 2013).

Some authors suggests that a suitable way to develop a theory on entrepreneurship opportunities is to identify the factors which can affect a person in the process of becoming an entrepreneur (C. I. Jones \& Romer, 2010; Leff, 1979). Such factors can play a role of facilitators in motivating and creating ease of doing business such as access to finance, human capital, regulatory quality and property rights (M. V. Jones, Coviello, \& Tang, 2011).

Ogundele et al. (2012) claimed that entrepreneurship training helps to create a productive environment to attain future challenges. In entrepreneurship facilitator, tertiary education and trainings are also essential activity which can develop necessary skills in a person to become an entrepreneur.

\subsection{Potential Control Variables}

\subsubsection{Relationship between Entrepreneurship and Economic Growth}

Georgiou (2009c) demonstrated that there is a significant relationship between entrepreneurship and economic growth. Entrepreneurship creates more jobs for people which will allow them to have more jobs in the market and enjoy a better standard of living (Georgiou, 2009b). Better entrepreneurial processes will grease the economic cycle of a nation. Entrepreneurship also increases life expectancy, like private hospitals where people come for their treatment and the services which fulfill the needs of people are likely to increase the life expectancy (Godiwalla \& Godiwalla, 2002). Similarly in developed countries, because of innovative entrepreneurial activities, a positive impact of entrepreneurial activities on economic growth can be clearly seen. (Acs \& Amorós, 2008; Stel et al., 2005; Tang \& Koveos, 2004; Wennekers et al., 2005)

According to Alvarez and Barney (2014), to enhance the economic growth, development in factors such as access to finance, property rights and human development significantly contribute in enhancing the entrepreneurial activities which are greatly helpful in alleviating poverty level of the country. Kaldor (1967), determined that better economic measures will enhance the performance of national industrialization. 
In economic theory, there is an ambiguous forecast relating to the correlation between entrepreneurship and business cycle. While some theories propose that in case economic decline, access to finance will also decrease which will affect job creation and entrepreneurial activities. (Rampini, 2004) . Moreover, in the period of economic recession, opportunity cost of potential entrepreneur will be lower which might as well imply a countercyclical relationship (Fairlie, 2013)

Economies of every country experiences three stages of development. First stage is about small scale production, second stage is about manufacturing and third stage is about providing services (Syrquin, 1988). Economics in the second stage of development will have less entrepreneurial activity where most of the people will be involved in manufacturing companies. But entrepreneurial activity increases in third stage of development (Blau, 1987). In developed economies, small size firms becomes larger organizations by using innovative techniques and effective use of resources (Acs, Audretsch, \& Evans, 1994). Later on, those large organizations that become a part of entrepreneurial activities which will introduce more job opportunities in market (Carree, Stel, Thurik, \& Wennekers, 2002). The share level of entrepreneurial activities decreases in manufacturing firms and increases in the level of services providing firms. In European Union countries (such as Sweden, Germany and etc.) and U.S. it is seen that firms providing services have created more opportunities for people to involve in entrepreneurial activities. (Acs, 2006)

Productive entrepreneurial environment is often thought to have an instrumental role in flourishing the economy by venturing into advanced business techniques paving the way for employment generation (Bhagwati \& Srinivasan, 2002). In the contemporary times, rising nations, with their enormous young labor strength accompanied by lower or medium-income class, have initiated to direct their strategies to boost entrepreneurial activities. The focus of local, regional and global media on entrepreneurship as an economic wheel which will help in the development of the nation.

The countries that are particularly flourishing economically with improved business scenario, have entrepreneurial activity that demonstrates strengthened strategic attitude, a welldefined shrinkage of new registrations during a crisis, and a swift revival of new registrations once the crisis has subsided (Klapper, Love, \& Randall, 2015). 


\subsubsection{Other Indicators and their role in Entrepreneurial Activities}

Hussain and Hanjra (2004) investigated the relationship between irrigation and poverty reduction. The results showed that there is positive relationship between irrigation and poverty alleviation. Development in irrigation will improve the standard of life of poor and also it will increase the purchasing power of poor people. Development in irrigation can mean massive production and more yields in market (Reardon \& Taylor, 1996). With the mass production the price of yield will drop and affordable for poor people. Moreover, irrigation development will help the country to enhance their economy. Government can facilitate farmers and poor people by launching suitable support programs (Dhawan \& Datta, 1992). The government has to develop a mechanism through which they can provide proper environment to motivate and attract farmers. To develop that environment, government need to consider five things: facilitate farmers in access to finance, provide advance agricultural machinery, good water management, provide good quality land for agriculture and reduce taxes while exporting yields (I. Hussain \& Hanjra, 2004). Bruton, Khavul, and Chavez (2011) determined that microfinance is a way to alleviate poverty. By reducing interest rate and easy access of microfinance, more people will be attracted to start a business.

Trade openness also plays a vital role in the development of economy. Countries such as South Korea (high-income country), China (high medium-income country) and Bangladesh (medium-income country) have been manufacturing electronic goods, auto industry products and garment etc. in order to boost their economy (Easterly, 2006). Lowering import/export barriers and facilitating across borders trade have helped nation to reduce political biases, respect each other's national policies and cultural values. Such linkage between the people of two different cultures will create more business opportunities by promoting business friendly environment that is conclusive for entrepreneurial activities (Murphy \& Coombes, 2009).

Ravallion (2006) examined the relationship between poverty and trade in the developing countries. In developing countries there has been an enormous growth in domestic accessibility of statistics over the last 15 years. This information shows that a substantial diversity exists amongst the poor people regarding their current trading scenario in the majority of markets. The people range from being net manufacturers to net purchasers of edible items. There lies a vital lesson in this diversity enabling fruitful discussion on trade and poverty. The overall gross disparity and mainstream poverty can conceal more than they disclose. 
Dollar and Kraay (2002) carried out a prominent analysis which established that trade capacity has a nearly non-existent impact on disparity. However, few studies also reported hostile effects on inequality (Dollar, 2005). According to Lundberg and Squire (2003), one of the studies shows that disparity or inequity is augmented by increased trade capacity. Milanovic (2005) and Ravallion (2001) illustrated that in developing and developed countries, higher trade capacity is diminishing equality but that the opposite situation occurs when the average income is appropriately high.

The advancements in level of growth will inevitably effect the repercussions of poverty. Empirical results showed that economic prosperity can be acquired through widened trade. This confirmation can be asserted in (among others) (Dollar, 1992; Edwards, 1998; Harrison, 1996; J. D. Sachs \& Warner, 1995)

According to Ravallion (2006) trade openness in a country can reduce the poverty level. China is an incomparable illustration of the previously mentioned analogy. It has overcame the prevalent poverty rates by leaps and bounds. This was made possible by a wide growth in trading capabilities dating back to the early 1980's. This is a historic turn of events. Even though China's proportion of poverty is somewhat lesser than the mean poverty ratio worldwide, it was a conflicting scenario around 1980's with China's poverty rates being highest among the countries round the globe. Many historians have proclaimed that Deng Xiaoping's " Open-Door Policy' at the start of 1980's was a better mechanism in achieving the ensuing battle against poverty (Dollar, 2005; World Bank, 2002). The assertion of the statement that increased openness in China's trade is a crucial factor in reducing poverty is being checked by Ravallion (2006). The experimental evidence includes information collected over a period of time. This information is separated and spanned over the time period ranging from 1980-2000. The description of dealings relating poverty is demonstrated in the beginning. The results showed that the position of flexibility and trade openness are the key factors which helped China's irrefutable victory over utter poverty.

After the Stolper-Samuelson debate, a likely inference would be that the poverty levels in underdeveloped countries can be reduced by trade openness; hence a modified benefit can be utilized to sell the physical goods overseas (Bhagwati \& Srinivasan, 2002). A. O. Krueger (1981) concluded this fundamental point by observing the impact of trade on earnings and livelihood in industrially emerging countries. The argument of trade being useful in the eradication of poverty is also supported by a different approach. Evidently, if a country adopts a policy that fosters exports 
that is different from the import-substituting policy, then the macro-economic firmness needs to be retained. The latter commonly implies using autonomous trade. This particular aspect of macroeconomic steadiness should be specified as an internal part of the strategic plan supporting freer trade.

According to Gould (1998), in North America North American Free Trade Agreement (NAFTA) helped the countries to strengthen their economies, creating employment and providing standard living to people. Beside that developed countries such as Canada have good relation with their neighboring country U.S. Such agreements between Canada and U.S. motivates people to become an entrepreneur and export their products. NAFTA has played a vital role in lowering the trade barriers between Mexico, U.S. and Canada.

Similarly, there are some factors which hinder the process of entrepreneurship in a country, such as protecting the rights of minority, labor market regulations and rights, getting electricity connection, dealing with construction permits, paying taxes and access to finance. (World Bank, 2016a, p. 6) .By considering these factors, the researcher will explain the role of entrepreneurship facilitators (Government, Incubators, and Financial Institutions) in developing a mechanism to support a person in the process of becoming an entrepreneur. That mechanism of entrepreneurship facilitator will generate more jobs which will allow people to overcome poverty.

\section{Decision to use HDI}

Based on the discussion above, Human Development Index (HDI) has been chosen as the dependent variable to measure poverty. Moreover, entrepreneurial facilitators has been used as a moderator between entrepreneurial activity and HDI. Furthermore, economic factors were used as control variable.

\subsection{Research Objectives}

The objective of this study is to investigate the role of entrepreneurship activity as measured by new business density and its impact on poverty alleviation. The objectives are:

- To examine the impact of entrepreneurial activity on poverty alleviation.

- To get an insight into how entrepreneurship facilitators (Government, Incubators, and Financial Institutions) change the business environment of a country which ultimately plays an important role in alleviating poverty. 
- To identify the relationship between entrepreneurship facilitators (Government, Incubators, and Financial Institutions) and their role in poverty alleviation by comparing both overall and in the differing cases of high-income countries, high medium-income countries, medium-income countries and low-income countries.

- To illustrate the role of entrepreneurship facilitators in developing a mechanism to support a person in the process of becoming an entrepreneur. That mechanism of entrepreneurship facilitator will generate more jobs and reduce poverty.

- To identify other controlling factors that influence poverty and Human Development Index (HDI)?

\subsection{Research Questions}

(1) What is the impact of entrepreneurial activity on poverty alleviation both overall and in the differing cases of high-income, high medium-income, medium-income and lowincome countries?

(2) Do entrepreneurship facilitators increase the effectiveness of entrepreneurship activity to reduce poverty?

(3) What other controlling factors exists which can significantly affect poverty?

Zoltan J. Acs (2006) examined the role of entrepreneurial activities in both developed (Japan, Sweden and Germany) countries and developing (Uganda, Peru and Ecuador) countries. To measure entrepreneurial activities, Zoltan J. Acs collected the data from Global Entrepreneurship Monitor (GEM) on both necessity entrepreneurship and opportunity entrepreneurship. The results showed that people are more inclined towards opportunity entrepreneurship in developing countries and there is a positive relationship between opportunity entrepreneurship and economic growth. Moreover, increase in entrepreneurial activities will create more jobs and alleviate poverty.

High-income countries have high HDI because high-income levels allow people to have better life, education and health (Todaro \& Smith, 2003). Similarly, high level income brings productivity in a country which raises the economic growth.

The quality of bureaucracy and its impact on corruption is very important to determine the ratio of number of business registered or business entry in a nation (Nistotskaya \& Cingolani, 
2016). There is a direct link between the quality of bureaucracy and the implementations of rules and regulation in a society. If the bureaucracy is honest and bureaucratic hurdles are minimum, the level of corruption will be low which will facilitate a person in the process of starting or registering a new business.

Entrepreneurial activities such as trade openness, services in hospitals, economic growth, and education can improve HDI (Georgiou, 2009a). If the performance of a country's institution is quick and cumbersome force then implementation of regulations can enhance the entrepreneurial activities and the impact of corruption will be less in the start of entrepreneurial activities. 


\section{CHAPTER 4}

\section{DATA AND METHODOLOGY}

\subsection{Motivation of the study}

This is one of many issues which World Bank wants to solve. In developing countries World Bank has launched different programs to improve the standards of life and alleviated poverty. This study has been undertaken to identify the factors which have direct relationship with ease of doing business and creating good business environment which in turn will help a person to become an entrepreneur.

\subsection{Research Hypothesis}

The aim of the current study is to investigate the role of entrepreneurship facilitators in alleviating poverty in high-income, high medium-income, medium-income, and low-income countries.

Specifically, to answer the questions as stated in the previous section, the current study tests the following hypotheses.

H1o: There is no significant relationship between entrepreneurial activity and poverty as measured by the Human Development Index (HDI).

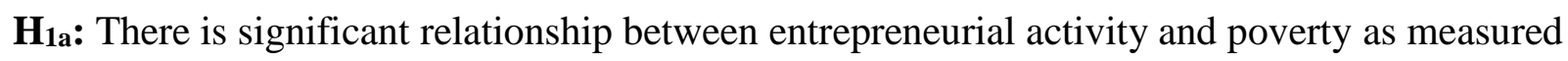
by the Human Development Index (HDI).

$\mathbf{H}_{20}$ : Entrepreneurial facilitators as measured by (average of time required to start the business, number of procedures required, cost to start a business, regulatory quality, and control for corruption) have no significant impact on the relationship between entrepreneurial activity and poverty as measured by the Human Development Index (HDI).

$\mathbf{H}_{2 \mathrm{a}}$ : Entrepreneurial facilitators as measured by (average of time required to start the business, number of procedures required, cost to start a business, regulatory quality, and control for corruption) have significant impact on the relationship between entrepreneurial activity and poverty as measured by the Human Development Index (HDI). 


\subsection{Theoretical Model}

Figure 4.1 presents the theoretical framework of the study and demonstrates the potential effect of entrepreneurial activity on Human Development Index (HDI). Additionally, Figure 4.1 illustrates the moderating effect of the entrepreneurial facilitators on the effects of entrepreneurial activity.

The controlling factors come from economic related factors. 
Figure 4.1 Theoretical Model

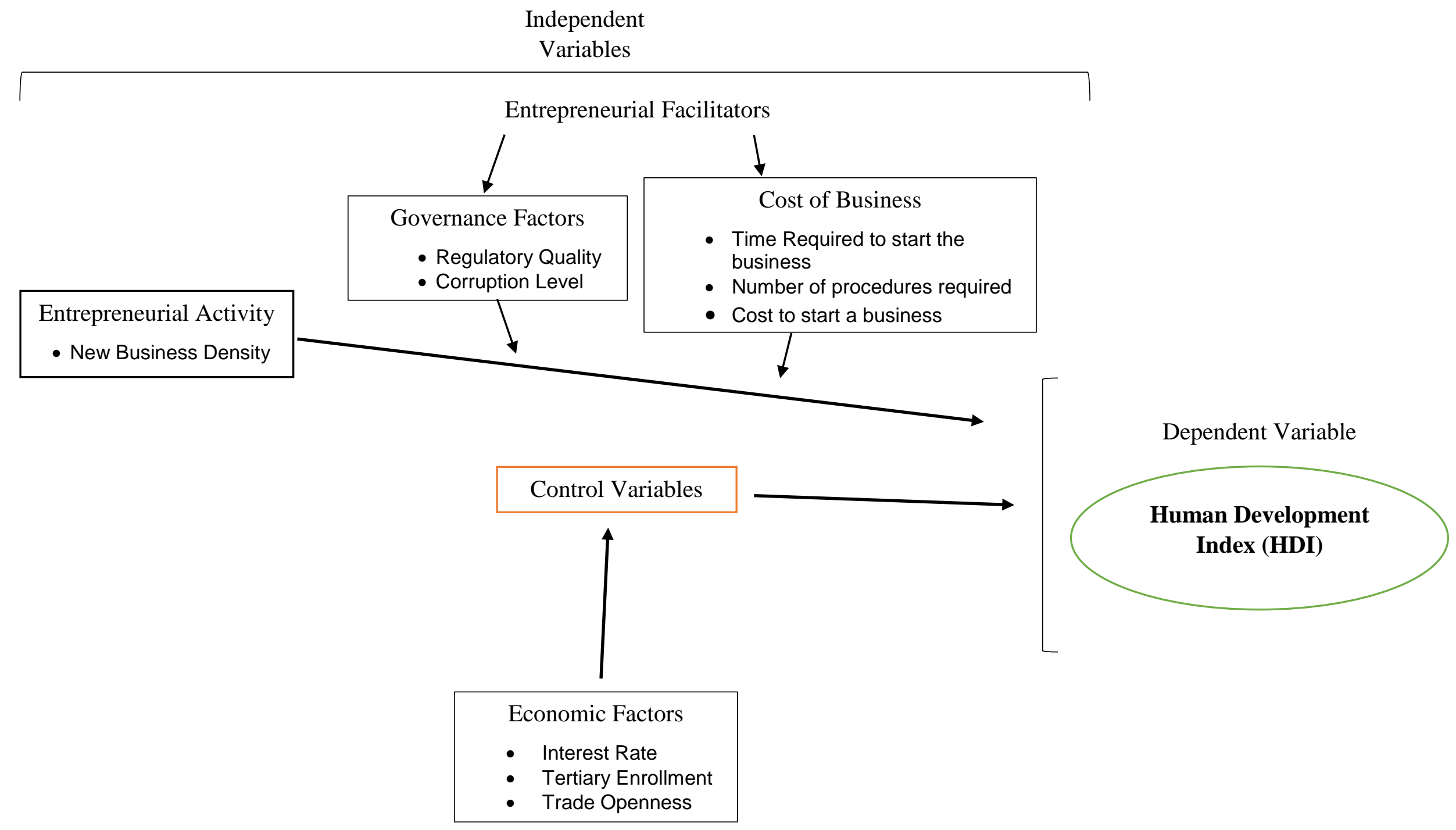




\subsection{Research Design}

This study uses a deductive approach, in which the hypotheses are tested for application across various country groups based on their development level. For this approach secondary quantitative data are used (Gabriel, 2013).

\subsection{Data and Sample}

The annual time series data of Human Development Index (HDI) were collected for the period of 2005 to 2016 from the United Nations Development Programme (UNDP, 2018) and World Development Indicators (World Bank, 2018) for all countries in the world and are used as a proxy to measure poverty in the countries categorized as high-income, high medium-income, mediumincome and low-income countries, respectively.

Time series data for independent variables including entrepreneurial activity, entrepreneurship facilitators, and economic factors have been collected from the different sources as discussed below.

First, entrepreneurship activity is proxied by business registered density and is collected annually for the period of 2005 to 2016 from the World Bank's Entrepreneurial Survey and Database.

Second, annual data for entrepreneurship facilitators is proxied by the average of the number of procedures required to start a business (PRS), time required to start a business and cost to start a business, regulatory quality and control for corruption is obtained from Doing Business Reports and World Development Indicator for the time period of 2005 to 2016.

Third, economic factor is comprised of interest rate, tertiary enrollment and trade openness and is collected annually for the period of 2005 to 2016 from World Development Indicators.

Table 4.1 shows the 189 countries which were used for analysis. Moreover, those countries have been presented into four country sets. 


\subsection{Functional Form}

The functional form used for this research is

Poverty $_{i t}=\mathrm{f}\left(\right.$ entrepreneurial activity $_{i t}$, entrepreneurial facilitators $_{i t}$, economic factors $\left._{i t}\right)$, where,

- Poverty will be measured by using Human Development Index (HDI) where HDI is a development method.

- Entrepreneurial activity comprises of business registered density.

- Entrepreneurial facilitators has two sub categories, cost of business and governance factors. Cost of business is average of time required to start the business, no of procedures required and cost to start a business and governance factors comprises regulatory quality and control for corruption.

- Economic factors comprise of interest rate, tertiary enrollment and trade openness.

- $\quad \mathrm{i}=\mathrm{is}$ countries in different income group i.e. high-income, high medium-income, medium-income and low-income groups

- $\mathrm{t}=$ is years 2005 to 2016

Human Development Index (HDI) and Governance factor are in index form, whereas for all other variables, the natural log was taken to convert them into index form. This analysis uses the natural log to linearize the model by reducing the effect of heteroskedasticity (Arshed, Anwar, Kousar, \& Bukhari, 2017).

\section{Moderation Approach}

While cost of entrepreneurship has no direct link with poverty, cost of entrepreneurship creates hurdles for new entrepreneurs. Moreover, it also reduces the capacity of entrepreneurial activity, thus it is considered as a moderator.

\subsection{Variables and sources}

Based on the functional form the following are the proposed but not limited to, variables for this study. Control variable are used to make model fit and reduce the missing variable bias as much 
as possible with keeping relevancy with the independent variable under consideration which is entrepreneurial activity. Table 4.2 shows the list of variables, definitions and their sources. 
Table 4.2 Variables, Types, Definitions and Sources

\begin{tabular}{|c|c|c|c|}
\hline Variables (Symbol) & Types & Definitions & Sources \\
\hline $\mathrm{HDI}$ & Dependent Variable & Measure of development (Index) & $\begin{array}{l}\text { Human Development } \\
\text { Reports (UNDP) }\end{array}$ \\
\hline $\begin{array}{l}\text { New Business Density } \\
\text { (NBD) }\end{array}$ & $\begin{array}{l}\text { Independent variable } \\
\text { (entrepreneurial activity) }\end{array}$ & $\begin{array}{l}\text { Registration per } 1000 \text { people ages } \\
15-64\end{array}$ & $\begin{array}{l}\text { World bank's } \\
\text { entrepreneurship survey } \\
\text { and database }\end{array}$ \\
\hline $\begin{array}{l}\text { Cost of new business } \\
\text { (CNB) }\end{array}$ & $\begin{array}{c}\text { Independent variable } \\
\text { (entrepreneurial facilitators) }\end{array}$ & $\%$ of GNI per capita & Doing Business Reports \\
\hline $\begin{array}{l}\text { Number of procedures } \\
\text { required for a start-up } \\
\text { (PRS) }\end{array}$ & $\begin{array}{c}\text { Independent variable } \\
\text { (entrepreneurial facilitators) }\end{array}$ & Number of procedures required & Doing Business Reports \\
\hline $\begin{array}{l}\text { Time required to start a } \\
\text { business (TRSB) }\end{array}$ & $\begin{array}{c}\text { Independent variable } \\
\text { (entrepreneurial facilitators) }\end{array}$ & $\begin{array}{c}\text { Number of days required to start a } \\
\text { business }\end{array}$ & Doing Business Reports \\
\hline $\begin{array}{l}\text { Control for Corruption } \\
\text { (CFC) }\end{array}$ & $\begin{array}{c}\text { Independent variable (governance } \\
\text { indicators) }\end{array}$ & $\begin{array}{c}\text { Index of perceptions of the extent to } \\
\text { which public power is exercised for } \\
\text { private gain }(-2.5 \text { to } 2.5)\end{array}$ & $\begin{array}{l}\text { Worldwide governance } \\
\text { indicators }\end{array}$ \\
\hline Regulatory Quality (RQ) & $\begin{array}{c}\text { Independent variable (governance } \\
\text { indicators) }\end{array}$ & $\begin{array}{l}\text { Index of perceptions of the ability of } \\
\text { the government to formulate and } \\
\text { implement sound policies and } \\
\text { regulations that permit and promote } \\
\text { private sector development (- } 2.5 \text { to } \\
2.5)\end{array}$ & $\begin{array}{l}\text { Worldwide governance } \\
\text { indicators }\end{array}$ \\
\hline Interest rate $(\mathrm{IR})$ & $\begin{array}{c}\text { Independent variable (economic } \\
\text { indicators) }\end{array}$ & Long run bond rate per annum & $\begin{array}{l}\text { World Development } \\
\text { Indicators }\end{array}$ \\
\hline Tertiary Enrollment (TE) & $\begin{array}{c}\text { Independent variable (economic } \\
\text { indicators) }\end{array}$ & $\%$ gross & $\begin{array}{l}\text { World Development } \\
\text { Indicators }\end{array}$ \\
\hline Trade openness (TO) & $\begin{array}{c}\text { Independent variable (economic } \\
\text { indicators) }\end{array}$ & Total trade (\% of GDP) & $\begin{array}{l}\text { World Development } \\
\text { Indicators }\end{array}$ \\
\hline
\end{tabular}




\subsection{Estimation Equation}

In order to fulfill the research objectives this study estimates the following model, where Entrepreneurial activity is EA, entrepreneurial facilitators is EF, and economic factors is ECO. This model will be estimated for four country groups provided in Table 4.1.

$$
H D I_{i t}=\alpha_{0}+\alpha_{1} E A_{i t}+\alpha_{2} E F_{i t}+\alpha_{3} E C O_{i t}+\varepsilon_{i t}
$$

\subsection{Estimation Approach}

Since the study uses panel data where each variable changes across countries and time, to make the model stable one of the pillars (out of time or cross section) must be made fixed. Under this approach there are four major types of models which were considered for utilization in this study (Greene, 2003; Gujarati, 2009). This study considered four models, as shown in Table 4.3.

Table 4.3 Competitive Models

\begin{tabular}{|l|l|}
\hline Model name & Assumption used \\
\hline Pooled OLS & $\begin{array}{l}\text { This model assumes that all the cross-sections are same while data only } \\
\text { changes in time. }\end{array}$ \\
\hline Fixed Effect Model & $\begin{array}{l}\text { This model assumes that all the cross-sections are quantitatively different } \\
\text { which can be controlled / measured using different intercepts }\end{array}$ \\
\hline Random Effect Model & $\begin{array}{l}\text { This model assumes that all the cross-sections are randomly different which } \\
\text { can be controlled using different intercepts }\end{array}$ \\
\hline $\begin{array}{l}\text { Panel Generalized Least } \\
\text { Squares }\end{array}$ & $\begin{array}{l}\text { This model assumes that underline cross-sections behave similarly but their } \\
\text { standard deviations are different }\end{array}$ \\
\hline
\end{tabular}

Panel Generalized Least Square was chosen, which helps to investigate the unknown factors in a linear regression model when there is a relationship between residuals in model (Zoltan J. Acs, Audretsch, Braunerhjelm, \& Carlsson, 2012; S. Miller \& Startz, 2018). 


\section{CHAPTER 5}

\section{RESULTS AND THEIR ANALYSIS}

As discussed earlier, the annual time series data of Human Development Index (HDI) were collected for the period of 2005 to 2016 from United Nations Development Programme (UNDP, 2018). Human Development Index (HDI) is used as a proxy to measure poverty in both all countries in the world and their sub group such as: high-income, high medium-income, mediumincome and low-income countries.

Thus, the dependent variable is Human Development Index (HDI) and the independent variable is entrepreneurial activity. Entrepreneurial facilitators is used as a moderator in between entrepreneurial activity and HDI. Moreover, economic factors is used as a control variable.

\subsection{Analysis of All Countries}

This section will focus on the estimation results of Human Development Index (HDI) in case of all countries in the world for which data are available. Thus, out of the 189 possible countries only 104 countries could be used in this analysis. Table 5.1 shows the list shows all countries for which data were collected and the countries with bold names were used in analysis. As might be expected the percentage of countries for which sufficient data were available reduces with lower levels of HDI. 
Table 5.1 All Countries segmented into High-Income, High Medium-Income, Medium-Income and Low-Income

\begin{tabular}{|c|c|c|c|}
\hline $\begin{array}{c}\text { High-Income } \\
\text { Countries }\end{array}$ & $\begin{array}{c}\text { High Medium-Income } \\
\text { Countries }\end{array}$ & Medium-Income Countries & Low-Income Countries \\
\hline Norway & Iran (Islamic Republic of) & Philippines & Solomon Islands \\
\hline Switzerland & Palau & South Africa & Papua New Guinea \\
\hline Australia & Seychelles & Egypt & Tanzania (United Rep.) \\
\hline Ireland & Costa Rica & Indonesia & Syrian Arab Republic \\
\hline Germany & Turkey & Viet Nam & Zimbabwe \\
\hline Iceland & Mauritius & Bolivia (Plurinational State of) & Nigeria \\
\hline Hong Kong, China & Panama & Palestine, State of & Rwanda \\
\hline Sweden & Serbia & Iraq & Lesotho \\
\hline Singapore & Albania & El Salvador & Mauritania \\
\hline Netherlands & Trinidad and Tobago & Kyrgyzstan & Madagascar \\
\hline Denmark & Antigua and Barbuda & Morocco & Uganda \\
\hline Canada & Georgia & Nicaragua & Benin \\
\hline United States & Saint Kitts and Nevis & Cabo Verde & Senegal \\
\hline United Kingdom & Cuba & Guyana & Comoros \\
\hline Finland & Mexico & Guatemala & Togo \\
\hline New Zealand & Grenada & Tajikistan & Sudan \\
\hline Belgium & Sri Lanka & Namibia & Afghanistan \\
\hline Liechtenstein & Bosnia and Herzegovina & India & Haiti \\
\hline Japan & Venezuela (Bolivarian Rep.) & Micronesia (Federated States of) & Côte d'Ivoire \\
\hline Austria & Brazil & Timor-Leste & Malawi \\
\hline Luxembourg & Azerbaijan & Honduras & Djibouti \\
\hline Israel & Lebanon & Bhutan & Ethiopia \\
\hline Korea (Republic of) & The former Yugoslav Rep. & Kiribati & Gambia \\
\hline France & Armenia & Bangladesh & Guinea \\
\hline Slovenia & Thailand & Congo & Congo (Democratic Rep.) \\
\hline Spain & Algeria & Vanuatu & Guinea-Bissau \\
\hline Czechia & China & Lao People's Democratic Rep. & Yemen \\
\hline Italy & Ecuador & Ghana & Eritrea \\
\hline Malta & Ukraine & Equatorial Guinea & Mozambique \\
\hline Estonia & Peru & Kenya & Liberia \\
\hline Greece & Colombia & Sao Tome and Principe & Mali \\
\hline Cyprus & Saint Lucia & Eswatini (Kingdom of) & Burkina Faso \\
\hline Poland & Fiji & Zambia & Sierra Leone \\
\hline United Arab Emirates & Mongolia & Cambodia & Burundi \\
\hline Andorra & Dominican Republic & Angola & Chad \\
\hline Lithuania & Jordan & Myanmar & South Sudan \\
\hline Qatar & Tunisia & Nepal & Central African Republic \\
\hline Slovakia & Jamaica & Pakistan & Niger \\
\hline Brunei Darussalam & Tonga & Cameroon & \\
\hline Saudi Arabia & Saint Vincent and the Grenadines & & \\
\hline Latvia & Suriname & & \\
\hline Portugal & Botswana & & \\
\hline Bahrain & Maldives & & \\
\hline Chile & Dominica & & \\
\hline Hungary & Samoa & & \\
\hline Croatia & Uzbekistan & & \\
\hline Argentina & Belize & & \\
\hline Oman & Marshall Islands & & \\
\hline Russian Federation & Libya & & \\
\hline Montenegro & Turkmenistan & & \\
\hline Bulgaria & Gabon & & \\
\hline Romania & Paraguay & & \\
\hline Belarus & Moldova (Republic of) & & \\
\hline \multicolumn{4}{|l|}{ Bahamas } \\
\hline \multicolumn{4}{|l|}{ Uruguay } \\
\hline \multicolumn{4}{|l|}{ Kuwait } \\
\hline \multicolumn{4}{|l|}{ Malaysia } \\
\hline \multicolumn{4}{|l|}{ Barbados } \\
\hline \multicolumn{4}{|l|}{ Kazakhstan } \\
\hline $\begin{array}{c}\text { Total: } 59 \text { (43 countries } \\
\text { were used in analysis = } \\
73 \% \text { ) }\end{array}$ & $\begin{array}{c}\text { Total: } 53 \text { (29 countries were } \\
\text { used in analysis }=54.7 \%)\end{array}$ & $\begin{array}{c}\text { Total: } 39 \text { (19 countries were } \\
\text { used in analysis }=48.7 \%)\end{array}$ & $\begin{array}{c}\text { Total: } 38 \text { (13 countries } \\
\text { were used in analysis = } \\
34.2 \%)\end{array}$ \\
\hline & tal of All Countries: $189(104 \mathrm{co}$ & ntries were used in analysis = & \\
\hline
\end{tabular}




\subsubsection{Estimation of Human Development Index (HDI) model of All Countries}

The estimated statistical results of all countries are shown in Figure 5.1.

Figure 5.1 Results of All Countries

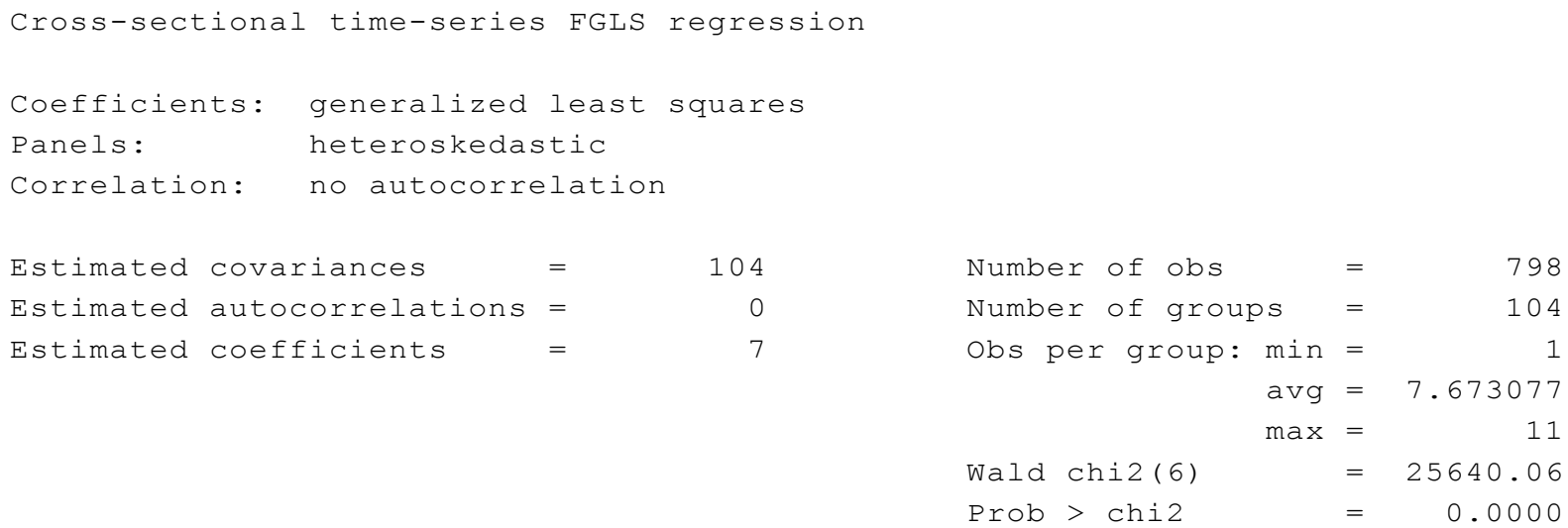

\begin{tabular}{|c|c|c|c|c|c|c|}
\hline hdi & Coef. & Std. Err. & $\mathrm{z}$ & $\mathrm{P}>|\mathrm{z}|$ & [95\% Conf. & Interval] \\
\hline lbusn & .0395856 & .003155 & 12.55 & 0.000 & .0334019 & .0457693 \\
\hline c.lbusn\#c.lcost & -.0108889 & .0014985 & -7.27 & 0.000 & -.013826 & -.0079519 \\
\hline c.lbusn\#c.gov & .0037229 & .0006832 & 5.45 & 0.000 & .0023838 & .0050621 \\
\hline lopen & .0079117 & .00169 & 4.68 & 0.000 & .0045995 & .011224 \\
\hline ledu & .0991204 & .001147 & 86.42 & 0.000 & .0968723 & .1013686 \\
\hline $\operatorname{lir}$ & -.037078 & .0014622 & -25.36 & 0.000 & -.0399439 & -.0342121 \\
\hline _cons & .4179056 & .0105175 & 39.73 & 0.000 & .3972916 & .4385195 \\
\hline
\end{tabular}

Key: Entrepreneurial Activity= Ibusn, Entrepreneurial Facilitators= Icost and gov, Trade Openness= lopen, Tertiary Enrollment $=$ ledu and Interest Rates $=$ lir

The estimated statistical results of all countries, as given in Figure 5.1 are based on a total sample of 798 country-year observations using 104 (55\% of all countries) countries and average years per cross section of 7.7. The Wald test with $\mathrm{p}$ value of 0.00 indicates that the overall model is fit, whereby all the independent variables are jointly explaining the dependent variable.

\section{Entrepreneurial Activity}

New Business Density: While exploring the individual effects, it indicates that one percent increase in new business density (busn) is associated with a 0.039 percent increase in Human Development Index (HDI), where the probability value confirmed the direct and significant effect in case of all countries. This direct effect is because of the fact that economic growth will take 
place because of high rate of business registered and good governance (Nistotskaya \& Cingolani, 2016).

\section{Entrepreneurial Facilitators}

Cost of Business: Meanwhile, the coefficient cross product of new business density and cost of business is negative. This indicates that every percentage increase in the cost of business is associated with a reduction of the capacity of new business to increase HDI by $0.011 \%$. Since the probability value of this coefficient is less than 0.05 , it is statistically significant. This negative coefficient shows that increase in cost of new business creates hurdles in capacity of new businesses to create jobs. More businesses registered will enhance entrepreneurial activities which will develop Human Development Index (HDI and reduce poverty. These results are similar to Gnyawali and Fogel (1994), Evans and Jovanovic (1989), Muravyev, Talavera, \& Schäfer (2009), Nistotskaya \& Cingolani (2016), and Cohen and Soto (2007).

Governance Factors: Results show that the coefficient cross product of new business density and governance factors (gov) index has direct relationship with Human Development Index (HDI) as mentioned by estimated value of 0.004 and it is significant with associated p-value of 0.000 . Moreover, it indicates that one unit increase in governance factor (gov) will increase the capacity of new business to increase Human Development Index (HDI) by 0.004 percent. If a country has good governance and less corruption, more businesses will likely be registered. Better governance can motivate people to start a business. If more businesses are registered, there should be more jobs available in market which will reduce poverty (Aidis, Estrin, and Mickiewicz, 2008; Bjørnskov \& Foss, 2010; Klapper et al., 2006; Nistotskaya \& Cingolani, 2016; Nyström, 2008; Stenholm et al., 2013).

Trade Openness: On the other hand, estimated results indicate that a one percent increase in the trade openness has positive and significant effect on HDI of 0.008 percent. This means that trade openness will allow people to learn new skills and increase HDI which will reduce poverty.

Tertiary Enrollment: Tertiary education enrollment has positive and significant effect on HDI. The results of tertiary enrollment demonstrates that one-percent increase in tertiary enrollment (edu) correlated with Human Development Index (HDI) to increase it by 0.099. The possible reason is that higher education makes individual more productive, creative and innovative. 
Moreover, it allows people to learn new knowledge and skills and improve the quality of their life. These results are similar to Davidsson and Honig (2003), Minniti and Lévesque (2010), R. E. Goldsmith and Kerr (1991), Ogundele, Akingbade and Akinlabi (2012) and Wang and Wong (2004) and Hussain, Bhuiyan and Bakar (2014).

Interest Rates: These results also demonstrate that interest rate has negative and significant coefficient, with p-value 0.000. It indicates that one-percent increase in interest rates effect HDI to decrease by 0.037 percent which is used as proxy to measure poverty in all countries.

The intercept value is significant and positive, it indicates that generally all countries have positive trend of HDI after controlling for the independent variables used in this study. 


\subsection{Analysis of High-Income Countries}

This section will focus on the estimation results of Human Development Index (HDI) in case of high-income countries in the world for which data are available. Thus, out of the 59 possible countries only 43 countries could be used in this analysis. Table 5.2 shows the list shows highincome countries for which data were collected and the countries with bold names were used in analysis.

Table 5.2 List of All High-Income Countries

\begin{tabular}{|l|l|l|}
\hline \multicolumn{3}{|c|}{ High-Income Countries } \\
\hline Norway & Japan & Brunei Darussalam \\
\hline Switzerland & Austria & Saudi Arabia \\
\hline Australia & Luxembourg & Latvia \\
\hline Ireland & Liechtenstein & Portugal \\
\hline Germany & Israel & Bahrain \\
\hline Iceland & Korea (Republic of) & Chile \\
\hline Hong Kong, China & France & Hungary \\
\hline Sweden & Slovenia & Croatia \\
\hline Singapore & Spain & Argentina \\
\hline Netherlands & Czechia & Oman \\
\hline Denmark & Italy & Russian Federation \\
\hline Canada & Malta & Montenegro \\
\hline United States & Estonia & Bulgaria \\
\hline United Kingdom & Greece & Romania \\
\hline Finland & Cyprus & Belarus \\
\hline New Zealand & Poland & Bahamas \\
\hline Belgium & United Arab Emirates & Uruguay \\
\hline Qatar & Andorra & Kuwait \\
\hline Slovakia & Lithuania & Malaysia \\
\hline Kazakhstan & Barbados & \\
\hline & &
\end{tabular}




\subsubsection{Estimation of Human Development Index (HDI) model of High-Income Countries}

The estimated statistical results of high-income countries are shown in Figure 5.2.

Figure 5.2 Results of High-Income Countries

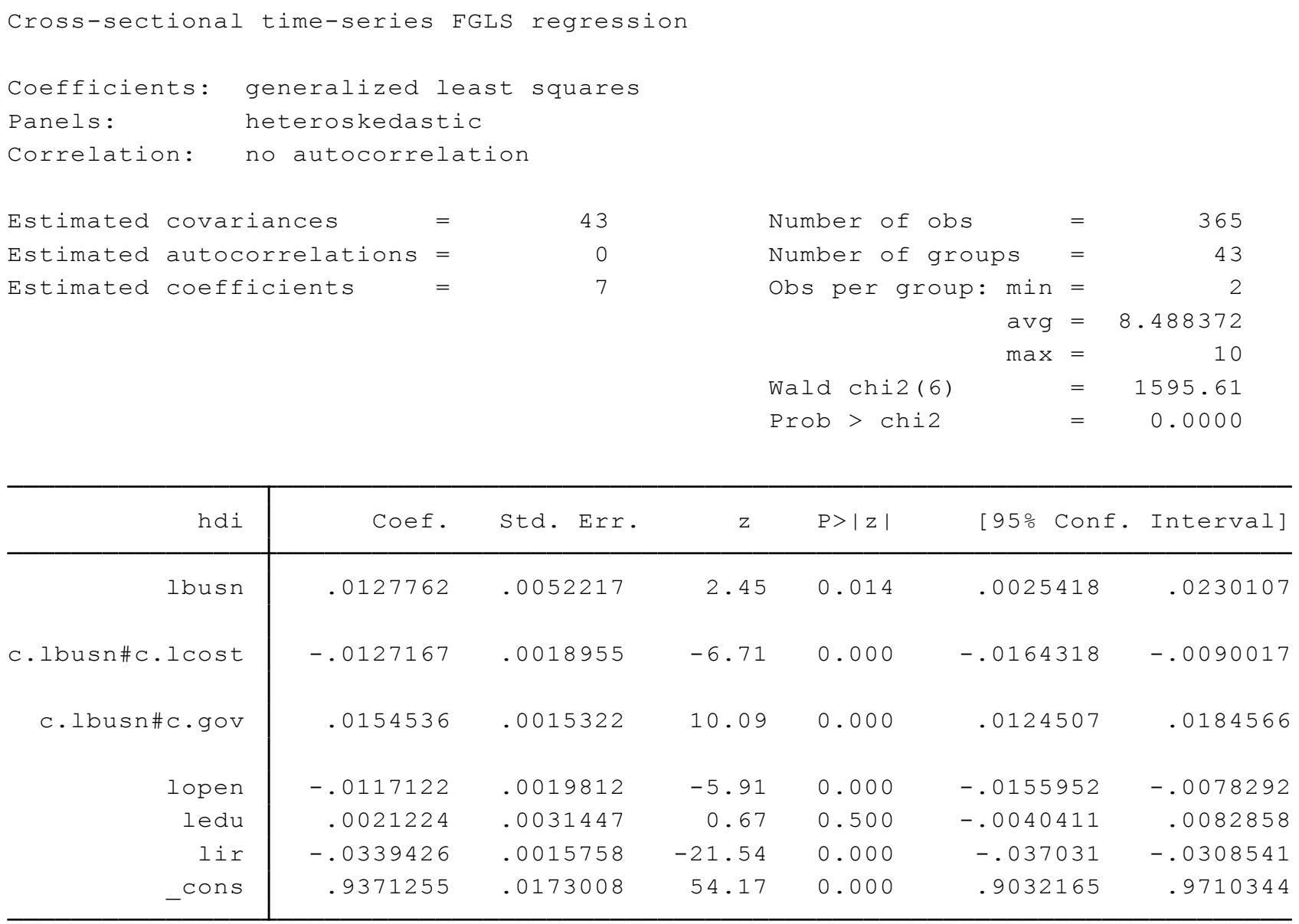

Key: Entrepreneurial Activity= Ibusn, Entrepreneurial Facilitators= Icost and gov, Trade Openness= lopen, Tertiary

Enrollment $=$ ledu and Interest Rates $=$ lir

The estimated statistical results of high-income countries, as given in Figure 5.2 are based on a total sample of 365 country-year observations using 43 (73\% of high-income countries) countries and average years per cross section of 8.48. The Wald test with $\mathrm{p}$ value of 0.00 indicates that the overall model is fit, whereby all the independent variables are jointly explaining the dependent variable. 


\section{Entrepreneurial Activity}

New Business Density: While exploring the individual effects, results indicates that one percent increase in new business density (busn) is associated with 0.013 percent increase in HDI, where the probability value confirmed the direct and significant effect in case of high-income countries including.

\section{Entrepreneurial Facilitators}

Cost of Business: The coefficient cross product of new business density and cost of business is negative. This indicates that every percentage increase in the cost of business is associated with a reduction of the capacity of new business to increase HDI by $0.012 \%$. Since the probability value of this coefficient is 0.000 , it is statistically significant. This negative coefficient indicates that an increase in cost of business creates hurdles in capacity of new businesses to create jobs. In this case a higher cost of starting a new business may demotivate entrepreneurs. High cost of starting a new business will reduce the total number of business registration which will reduce HDI. These results are similar to Gnyawali and Fogel (1994), Evans and Jovanovic (1989), Muravyev, Talavera, \& Schäfer (2009), Nistotskaya \& Cingolani (2016), and Cohen and Soto (2007).

Governance Factor: Results show that the coefficient cross product of new business density and governance factors (gov) index has direct and significant relationship with Human Development Index (HDI) as mentioned by estimated value of 0.015 and it is significant with associated p-value of 0.000. Moreover, it indicates that one unit increase in governance factor (gov) will increase the capacity of new business to increase HDI by 0.015 percent. Better governance and less corruption will increase the capacity of new business to increase HDI.

Trade Openness: On the other hand, estimated results indicate that 1 percent increase in the trade openness has a negative and significant effect on HDI of 0.011 percent as depicted from its coefficient and p-value being 0.000. These results differ from Murphy and Coombes (2009), Georgiou (2009a), Bhagwati and Srinivasan (2002) and Ravallion (2006).

Tertiary Enrollment: Tertiary education enrollment has a positive and insignificant effect on HDI associated with p-value (0.500). The results of tertiary enrollment demonstrates that one-percent increase in tertiary enrollment (edu) impact Human Development Index (HDI) to increase by 0.002. The possible reason is that higher education makes individual more productive, creative 
and innovative. Moreover, it allows people to learn new knowledge and skills and improve the quality of their life. These results are similar to Davidsson and Honig (2003), Minniti and Lévesque (2010), R. E. Goldsmith and Kerr (1991), Ogundele, Akingbade and Akinlabi (2012) and Wang and Wong (2004) and Hussain, Bhuiyan and Bakar (2014).

Interest Rates: The results demonstrate that interest rate has negative and significant coefficient, with p-value 0.000. It indicates that one-percent increase in interest rates effect HDI to decrease by 0.034 percent, which is used as proxy to measure poverty in high-income countries. This may be because of the fact that increase in interest rate increases cost of capital forcing business to reduce their debt financing and consequently may lead to laying off of labor. Low interest rates will allow entrepreneurs to start their businesses which will create more jobs and reduce poverty.

The intercept value is significant and positive, it indicates that generally high-income countries have positive trend of HDI after controlling for the independent variables used in this study. 


\subsection{Analysis of High Medium-Income Countries}

This section will focus on the estimation results of Human Development Index (HDI) in case of high medium-income countries in the world for which data are available. Thus, out of the 53 possible countries only 29 countries could be used in this analysis. Table 5.3 shows the list shows high medium-income countries for which data were collected and the countries with bold names were used in analysis.

Table 5.3 List of All High Medium-Income Countries

\begin{tabular}{|l|l|l|l|}
\hline \multicolumn{4}{|c|}{ High Medium-Income Countries } \\
\hline $\begin{array}{l}\text { Iran (Islamic Republic } \\
\text { of) }\end{array}$ & Mexico & Ecuador & Suriname \\
\hline Palau & Grenada & Ukraine & Botswana \\
\hline Seychelles & Sri Lanka & Peru & Maldives \\
\hline Costa Rica & Bosnia and Herzegovina & Colombia & Dominica \\
\hline Turkey & $\begin{array}{l}\text { Venezuela (Bolivarian } \\
\text { Rep.) }\end{array}$ & Saint Lucia & Samoa \\
\hline Mauritius & Brazil & Fiji & Uzbekistan \\
\hline Panama & Azerbaijan & Mongolia & Belize \\
\hline Serbia & Lebanon & Dominican Republic & Marshall Islands \\
\hline Albania & The former Yugoslav Rep. & Jordan & Libya \\
\hline Trinidad and Tobago & Armenia & Tunisia & Turkmenistan \\
\hline Antigua and Barbuda & Thailand & Jamaica & Gabon \\
\hline Georgia & Algeria & Tonga & Paraguay \\
\hline Saint Kitts and Nevis & China & $\begin{array}{l}\text { Saint Vincent and the } \\
\text { Grenadines }\end{array}$ & $\begin{array}{l}\text { Moldova (Republic } \\
\text { of) }\end{array}$ \\
\hline Cuba & & & \\
\hline \multicolumn{2}{|l}{} & \\
\hline
\end{tabular}




\subsubsection{Estimation of Human Development Index (HDI) model of High Medium-Income Countries}

The estimated statistical results of high medium-income countries are shown in Figure 5.3.

Figure 5.3 Results of High Medium-Income Countries

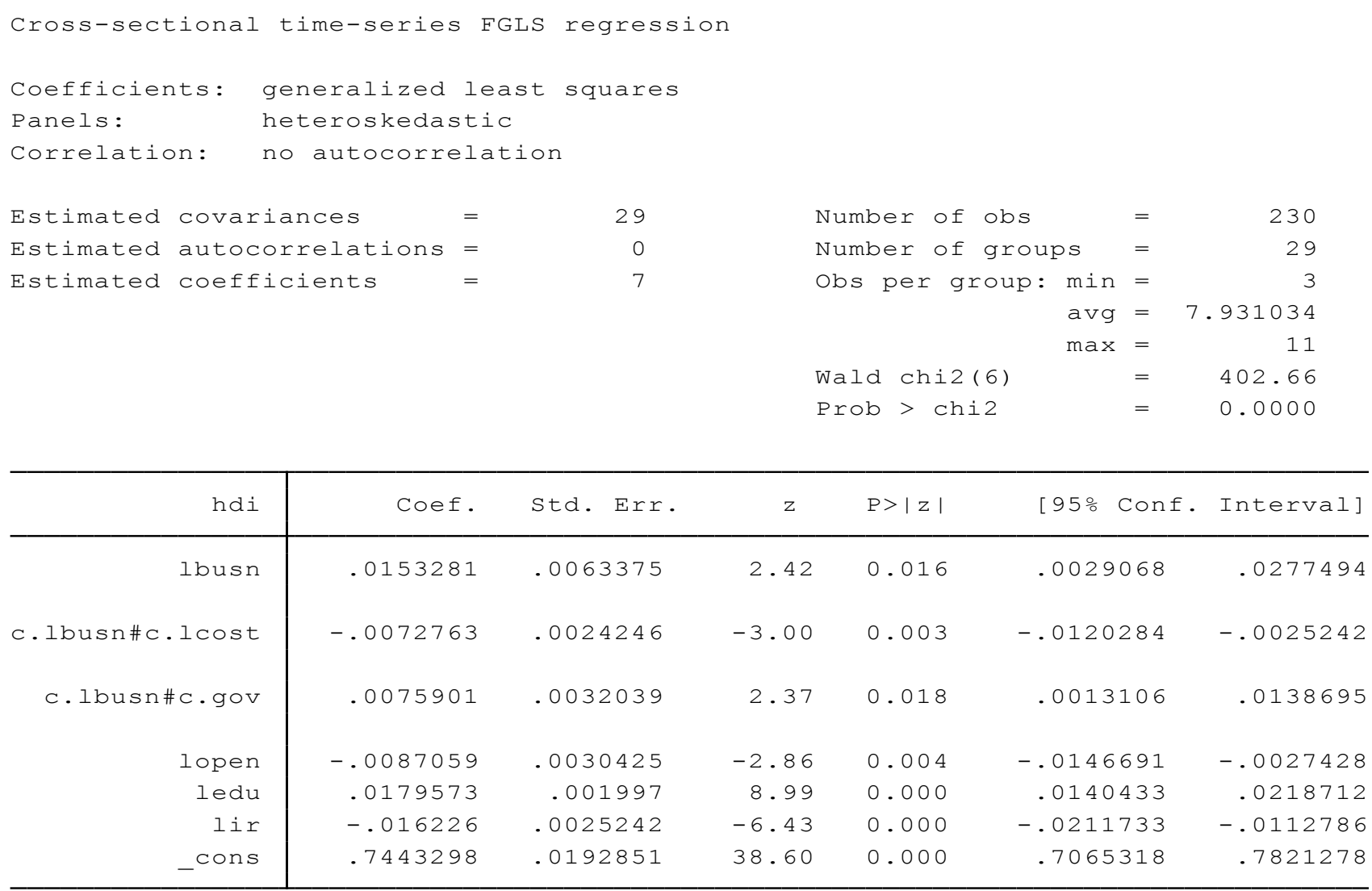

Key: Entrepreneurial Activity= Ibusn, Entrepreneurial Facilitators $=$ Icost and gov, Trade Openness $=$ lopen,

Tertiary Enrollment= ledu and Interest Rates $=$ lir

These results are based on a total sample of 230 country-year observations using $29(54.7 \%$ of high medium-income countries) countries and average years per cross section of 7.9. The Wald test with $\mathrm{p}$ value of 0.00 indicates that the overall model is fit, whereby all the independent variables are jointly explaining the dependent variable.

\section{Entrepreneurial Activity}

New Business Density: While exploring the individual effects, it indicates that one percent increase in new business density (busn) is associated with 0.02 percent increase in Human 
Development Index (HDI), where the probability value confirmed the significant effect in case of high medium-income countries.

\section{Entrepreneurial Facilitators}

Cost of Business: Meanwhile, the coefficient cross product of new business density and cost of business is negative. This indicates that for every percentage increase in the cost of starting new business is associated with a reduction of the capacity of new businesses to increase HDI by $0.007 \%$. Since the probability value of this coefficient is 0.016 , it is statistically significant.

Governance Factors: Results show that the coefficient cross product of new business density and governance factors (gov) index has direct relationship with Human Development Index (HDI) as mentioned by estimated value of 0.008 and it is significant with associated p-value of 0.003 . Moreover, it indicates that one unit increase in governance factor (gov) will increase the capacity of new business to increase HDI by 0.008 percent. Better governance will motivate people to start a business. If more businesses are registered, there will be more jobs available in market which will reduce poverty. If a country has good governance and less corruption, more businesses will be registered. These results are similar to Aidis, Estrin and Mickiewicz (2008), Bjørnskov and Foss (2010), Klapper, Laeven, and Rajan (2006), Nistotskaya and Cingolani (2016), Nyström (2008) and Stenholm, Acs, and Wuebker (2013).

Trade Openness: On the other hand, estimated results indicate that a 1 percent increase in the trade openness has negative and significant effect on HDI of 0.009 percent as depicted from its coefficient and p-value being 0.004. This means one percent increase in trade openness will decrease HDI by 0.009 percent.

Tertiary Enrollment: Similarly, the results of tertiary enrollment demonstrates that one-percent increase in tertiary enrollment (EDU) effects Human Development Index (HDI) to increase by 0.018. The p-value being 0.000 shows that it is significant. These findings are similar with Davidsson and Honig (2003), Minniti and Lévesque (2010), R. E. Goldsmith and Kerr (1991), Ogundele, Akingbade and Akinlabi (2012) and Wang and Wong (2004) and Hussain, Bhuiyan and Bakar (2014) 
Interest Rates: The results demonstrates that interest rate has negative and significant coefficient, with p-value 0.000. It indicates that one-percent increase in interest rates effects HDI to decrease by 0.02 percent which is used as proxy to measure poverty in high medium-income countries.

The intercept value is significant and positive, it indicates that generally high mediumincome countries have positive trend of HDI after controlling for the independent variables used in this study. 


\subsection{Analysis of Medium-Income Countries}

This section will focus on the estimation results of Human Development Index (HDI) in case of medium-income countries in the world for which data are available. Thus, out of the 39 possible countries only 19 countries could be used in this analysis. Table 5.4 shows the list shows mediumincome countries for which data were collected and the countries with bold names were used in analysis.

Table 5.4 List of All Medium-Income Countries

\begin{tabular}{|l|l|l|}
\hline \multicolumn{3}{|c|}{ Medium-Income Countries } \\
\hline Philippines & Guyana & Lao People's Democratic Republic \\
\hline South Africa & Guatemala & Ghana \\
\hline Egypt & Tajikistan & Equatorial Guinea \\
\hline Indonesia & Namibia & Kenya \\
\hline Viet Nam & India & Sao Tome and Principe \\
\hline Bolivia (Plurinational State of) & Micronesia (Federated States of) & Eswatini (Kingdom of) \\
\hline Palestine, State of & Timor-Leste & Zambia \\
\hline Iraq & Honduras & Cambodia \\
\hline El Salvador & Bhutan & Angola \\
\hline Kyrgyzstan & Kiribati & Myanmar \\
\hline Morocco & Bangladesh & Nepal \\
\hline Nicaragua & Congo & Pakistan \\
\hline Cabo Verde & Vanuatu & Cameroon \\
\hline \multicolumn{2}{|c|}{} \\
\hline
\end{tabular}




\subsubsection{Estimation of Human Development Index (HDI) model of Medium-Income Countries}

The estimated statistical results of medium-income countries are shown in Figure 5.4.

\section{Figure 5.4 Results of Medium-Income Countries}

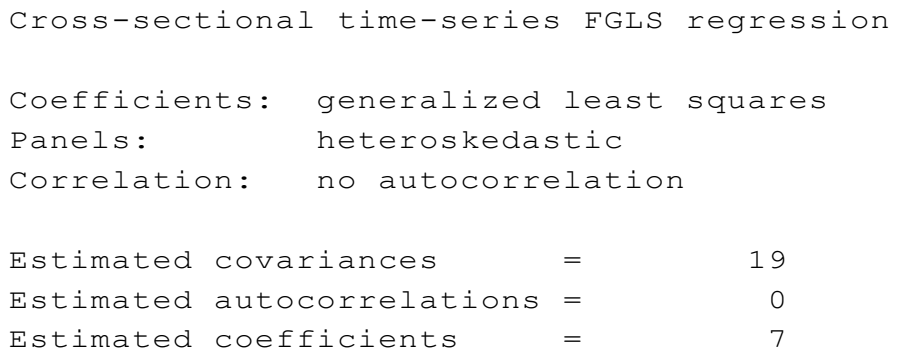

\begin{tabular}{|c|c|c|c|c|c|c|}
\hline hdi & Coef. & std. Err. & z & $P>|z|$ & [95\% Conf. & Interval] \\
\hline 1 busn & .0257786 & .0091142 & 2.83 & 0.005 & .007915 & .0436422 \\
\hline c. 1 busn\#c. I cost & -.0080134 & .0036832 & -2.18 & 0.030 & -.0152325 & -.0007944 \\
\hline c. Ibusn\#c.gov & .0063454 & .0021418 & 2.96 & 0.003 & .0021477 & .0105432 \\
\hline lopen & .0301098 & .0048592 & 6.20 & 0.000 & .0205859 & .0396337 \\
\hline ledu & .0608955 & .0030985 & 19.65 & 0.000 & .0548226 & .0669684 \\
\hline lir & -.0093725 & .003124 & -3.00 & 0.003 & -.0154955 & -.0032496 \\
\hline _cons & .3273795 & .0228315 & 14.34 & 0.000 & .2826306 & .3721284 \\
\hline
\end{tabular}

Key: Entrepreneurial Activity= Ibusn, Entrepreneurial Facilitators $=$ Icost and gov, Trade Openness $=$ lopen, Tertiary Enrollment= ledu and Interest Rates= lir

These results are based on a total sample of 125 country-year observations using $19(48.7 \%$ of medium-income countries) countries and average years per cross section of 6.5. The Wald test with $\mathrm{p}$ value of 0.00 indicates that the overall model is fit, whereby all the independent variables are jointly explaining the dependent variable.

\section{Entrepreneurial Activity}

New Business Density: While exploring the individual effects, it indicates that one percent increase in new business density (busn) is associated with 0.03 percent increase in Human Development Index (HDI), where the probability value confirmed the significant effect in case of medium-income countries. 


\section{Entrepreneurial Facilitators}

Cost of Business: Meanwhile, the coefficient cross product of new business density and cost of business is negative. This indicates that for every percentage increase in the cost of business is associated with a reduction of the capacity of new business to decrease HDI by $0.008 \%$. Since the probability value of this coefficient is less than 0.05 , so it is statistically significant.

Governance Factors: Results show that the coefficient cross product of new business density and governance factors (gov) index has direct relationship with Human Development Index (HDI) as mentioned by estimated value of 0.006 and it is significant with associated p-value of 0.003 . Moreover, it indicates that one unit increase in governance factor (gov) will increase the capacity of new business to increase HDI by 0.006 percent. If a country has good governance and less corruption, more businesses will be registered. Better governance will motivate people to start a business. If more businesses are registered, there will be more jobs available in market which will reduce poverty (Aidis, Estrin, and Mickiewicz, 2008; Bjørnskov \& Foss, 2010; Klapper et al., 2006; Nistotskaya \& Cingolani, 2016; Nyström, 2008; Stenholm et al., 2013).

Trade Openness: On the other hand, estimated results indicate that the trade openness has positive and significant effect on HDI of 0.03 percent as depicted from its coefficient and p-value being 0.000. Moreover, one percent increase in trade openness will increase HDI by $0.03 \%$.

Tertiary Enrollment: Similarly, the results of tertiary enrollment demonstrates that one-percent increase in tertiary enrollment (edu) effects HDI to increase by 0.06 percent which is used as a proxy to measure poverty in medium-income countries. The value is significant with p-value of 0.000. Better education will help people to learn new knowledge and skills. These results are similar to Davidsson and Honig (2003), Minniti and Lévesque (2010), R. E. Goldsmith and Kerr (1991), Ogundele, Akingbade and Akinlabi (2012) and Wang and Wong (2004) and Hussain, Bhuiyan and Bakar (2014).

Interest Rates: The result demonstrates that interest rate has negative and significant coefficient, with p-value 0.003. It indicates that one-percent increase in interest rates will decrease HDI by 0.009 percent which is used as proxy to measure poverty in medium-income countries. 
The intercept value is significant and positive, it indicates that generally medium-income countries have positive trend of HDI after controlling for the independent variables used in this study. 


\subsection{Analysis of Low-Income Countries}

This section will focus on the estimation results of Human Development Index (HDI) in case of low-income countries in the world for which data are available. Thus, out of the 38 possible countries only 13 countries could be used in this analysis. Table 5.5 shows the list shows lowincome countries for which data were collected and the countries with bold names were used in analysis.

Table 5.5 List of All Low-Income Countries

\begin{tabular}{|l|l|l|}
\hline \multicolumn{2}{|c|}{ Low-Income Countries } \\
\hline Solomon Islands & Comoros & Congo (Democratic Rep.) \\
\hline Papua New Guinea & Togo & Guinea-Bissau \\
\hline Tanzania (United Rep.) & Sudan & Yemen \\
\hline Syrian Arab Republic & Afghanistan & Eritrea \\
\hline Zimbabwe & Haiti & Mozambique \\
\hline Nigeria & Côte d'Ivoire & Liberia \\
\hline Rwanda & Malawi & Mali \\
\hline Lesotho & Djibouti & Burkina Faso \\
\hline Mauritania & Ethiopia & Sierra Leone \\
\hline Madagascar & Gambia & Burundi \\
\hline Uganda & Guinea & Chad \\
\hline Benin & Niger & South Sudan \\
\hline Senegal & & Central African Republic \\
\hline \multicolumn{2}{|l}{ Total: $\mathbf{3 8}$ countries were used in analysis = 34.2\%) } \\
\hline
\end{tabular}




\subsubsection{Estimation of Human Development Index (HDI) model of Low-Income Countries}

The estimated statistical results of low-income countries are shown in Figure 5.5.

Figure 5.5 Results of Low-Income Countries

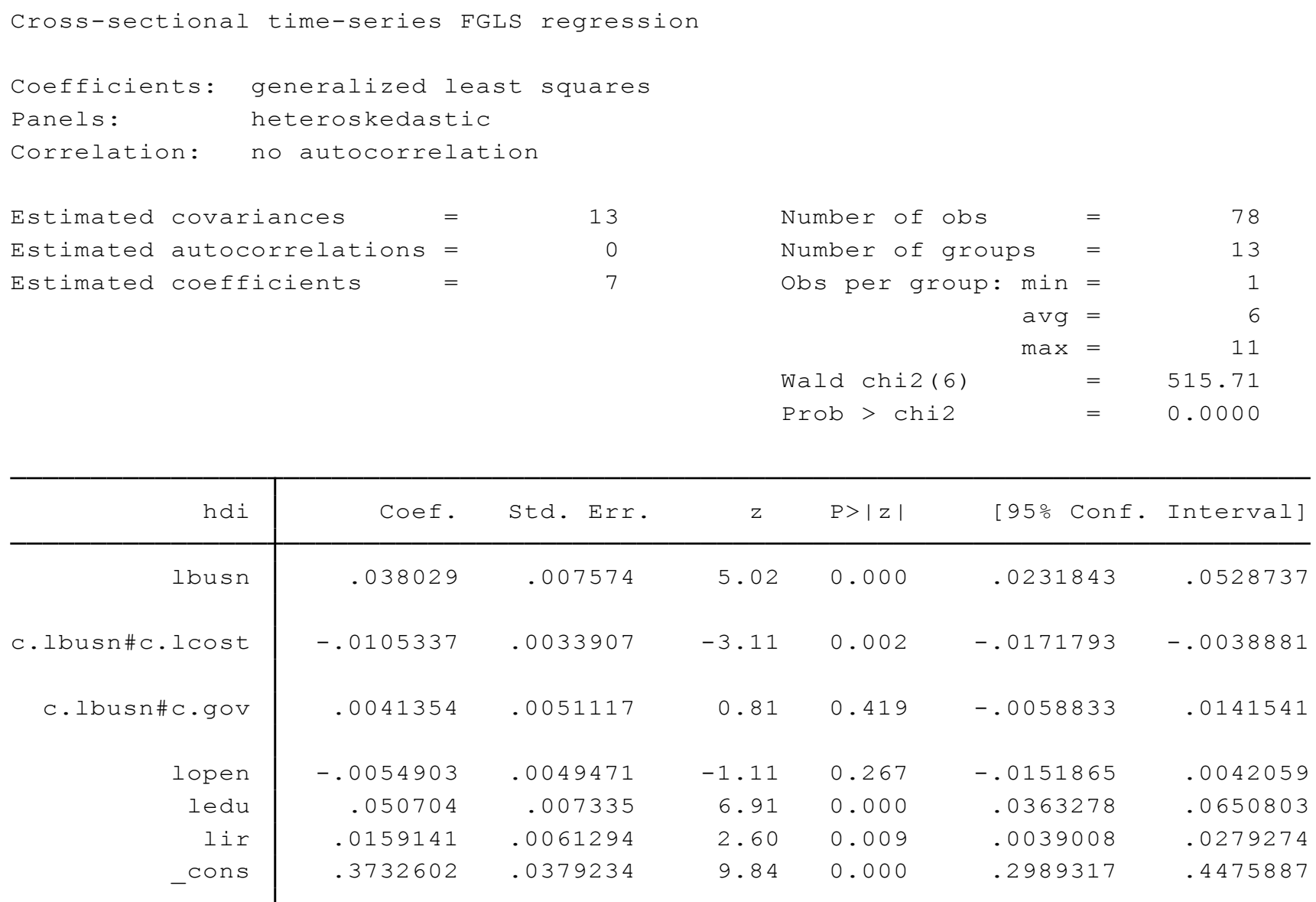

Key: Entrepreneurial Activity= lbusn, Entrepreneurial Facilitators= Icost and gov, Trade Openness= lopen, Tertiary

Enrollment= ledu and Interest Rates $=$ lir

The estimated statistical results of low-income countries, as given in Figure 5.5. These results are based on a total sample of 78 country year observations using 13 (34.2\% of low-income countries) countries and average years per cross section of 6.0. The Wald test with p value of 0.00 indicates that the overall model is fit, whereby all the independent variables are jointly explaining the dependent variable.

\section{Entrepreneurial Activity}

New Business Density: While exploring the individual effects, it indicates that one percent increase in new business density (busn) is associated with 0.038 percent increase in Human 
Development Index (HDI), where the probability value confirmed the significant effect in case of low-income countries.

\section{Entrepreneurial Facilitators}

Cost of Business: Meanwhile, the coefficient cross product of new business density and cost of business is negative. This indicates that for every percentage increase in the cost of business is associated with a reduction of the capacity of new business to increase HDI by $0.01 \%$. Since the probability value of this coefficient is 0.002 , it is statistically significant.

Governance Factors: Results show that the coefficient cross product of new business density and governance factors (gov) index has positive relationship with Human Development Index (HDI) as mentioned by estimated value of 0.004 and the probability value of this coefficient is 0.419 , it is statistically insignificant. Moreover, it indicates that one unit increase in governance factor (gov) increases the capacity of new business density to increase HDI by 0.004 percent. These findings are similar from Aidis, Estrin, and Mickiewicz (2008), Bjørnskov and Foss (2010) and Nyström (2008).

Trade Openness: On the other hand, estimated results indicate that one percent increase in the trade openness has indirect and insignificant effect on HDI of 0.005 percent as depicted from its coefficient and p-value being 0.267 .

Tertiary Enrollment: Similarly, the results of tertiary enrollment shows that there is positive and significant relationship with HDI, where p-value is (0.000). Moreover, the results of tertiary enrollment demonstrates that one-percent increase in tertiary enrollment (edu) effects Human Development Index (HDI) to increase by 0.05 percent which is used as a proxy to measure poverty in low-income countries. The possible reason is that higher education makes individual more productive, creative and innovative. Moreover, it allows people to learn new knowledge and skills and improve the quality of their life. These results are similar to Davidsson and Honig (2003), Minniti and Lévesque (2010), R. E. Goldsmith and Kerr (1991), Ogundele, Akingbade and Akinlabi (2012) and Wang and Wong (2004) and Hussain, Bhuiyan and Bakar (2014).

Interest Rates: Besides, results demonstrate that interest rate has positive and significant coefficient, with p-value 0.009. It indicates that one-percent increase in interest rates effects HDI to increase by 0.016 percent. Increase in interest rates will enhance human development index. 
The intercept value is significant and positive, it indicates that generally low-income countries have positive trend of HDI after controlling for the independent variables used in this study. 


\section{CHAPTER 6}

\section{DISCUSSION}

As discussed in Chapter 1, the purpose of this thesis is to understand the role of entrepreneurship in alleviating poverty. Specifically, it provides an insight into how entrepreneurship facilitators (Government, Incubators, and Financial Institutions) help in improving the business environment and increase the effectiveness of entrepreneurship activities in both all countries in the world and their sub sets into high-income, high medium-income, medium-income and low-income countries. Moreover, this thesis examines the impact of entrepreneurial activities on poverty alleviation and identifies some other controlling factors which can affect poverty.

Each country has its own poverty definition and the method to measure poverty also varies from country to country. Thus, in this thesis, Human Development Index (HDI) has been used as the primary proxy to measure poverty.

To check the overall impact of entrepreneurial activity on HDI, the analysis was run on both all countries in the world as well as on their sub groups. The results showed that there is a positive and significant relationship between entrepreneurial activity and HDI. In all countries, when more businesses are registered then this can bring more jobs and create more opportunities for people to overcome their poverty. It can also help to grease the economic wheel of the country. Economic growth will take place because of a higher rate of business registered and good governance. By improving regulatory laws and control for corruption, governments can ensure property rights which will facilitate entrepreneurs and motivate them to start new businesses or expand their existing businesses. New business enterprises and innovation plays a vital role for the development of economic growth and alleviating poverty. 


\subsubsection{Overall Discussion of Human Development Index Model (HDI)}

The results for all countries and their sub sets are shown in Table 6.1.

Table 6.1 Relationship between Human Development Index (HDI) and Independent Variables

\begin{tabular}{|c|c|c|c|c|c|c|c|}
\hline \multicolumn{8}{|c|}{ Results of All Countries } \\
\hline \multicolumn{2}{|c|}{ Variables } & \multirow{2}{*}{$\begin{array}{c}\text { Symbol } \\
\text { busn }\end{array}$} & \multirow{2}{*}{$\begin{array}{c}\begin{array}{c}\text { High- } \\
\text { Income } \\
\text { Countries }\end{array} \\
+ \text { ve/sig }\end{array}$} & \multirow{2}{*}{$\begin{array}{c}\text { High } \\
\text { Medium- } \\
\text { Income } \\
\text { Countries } \\
+ \text { ve/ sig }\end{array}$} & \multirow{2}{*}{$\begin{array}{c}\begin{array}{c}\text { Medium- } \\
\text { Income } \\
\text { Countries }\end{array} \\
+ \text { ve/sig }\end{array}$} & \multirow{2}{*}{$\begin{array}{c}\text { Low- } \\
\text { Income } \\
\text { Countries } \\
+ \text { ve/sig }\end{array}$} & \multirow{2}{*}{$\begin{array}{c}\begin{array}{c}\text { All } \\
\text { Countries } \\
\text { HDI }\end{array} \\
+ \text { ve/sig }\end{array}$} \\
\hline $\begin{array}{l}\text { Entrepreneurial } \\
\text { Activity }\end{array}$ & $\begin{array}{l}\text { New Business } \\
\text { Density }\end{array}$ & & & & & & \\
\hline \multirow{2}{*}{$\begin{array}{l}\text { Entrepreneurial } \\
\text { Facilitators }\end{array}$} & Cost of Business & busn ${ }^{*} \operatorname{cost}$ & -ve/sig & -ve/sig & -ve/sig & -ve/sig & -ve/sig \\
\hline & Governance Factors & busn $^{\star}$ gov & + ve/sig & +ve/sig & +ve/sig & +ve/insig & $+\mathrm{ve} / \mathrm{sig}$ \\
\hline Control Variable & Trade Openness & open & -ve/sig & -ve/sig & + ve/sig & -ve/insig & + ve/sig \\
\hline Control Variable & Tertiary Enrollment & edu & +ve/insig & $+\mathrm{ve} / \mathrm{sig}$ & $+\mathrm{ve} / \mathrm{sig}$ & $+\mathrm{ve} / \mathrm{sig}$ & $+\mathrm{ve} / \mathrm{sig}$ \\
\hline Control Variable & Interest rates & $\mathrm{Ir}$ & -ve/sig & -ve/sig & -ve/sig & $+\mathrm{ve} / \mathrm{sig}$ & -ve/sig \\
\hline
\end{tabular}

\section{Entrepreneurial Activity}

Table 6.1 shows the relationship between HDI and independent variables. Entrepreneurial activities comprise of new business density, where new business density is the total number of business registration. This shows that entrepreneurial activities increase with an increase in new business density. More business registration will bring more employment in a country. This means that more businesses registered will allow people to improve their standard of life. The purchasing power will also increase with the increase of new business registration. The results showed that entrepreneurial activity have positive and significant impact on HDI in all countries in the world and as well as in their sub groups high-income, high medium-income, medium-income and low-income countries.

\section{Entrepreneurial Facilitators}

Entrepreneurial facilitators is a cross product of new business density and cost of business. Cost of business is an average of three costs which are time required to start a business, number of procedures required and cost of starting a business. It is assumed that when the cost to start a business increases, it may demotivate entrepreneurs and reduce the impact of new businesses registered on HDI. Fewer entrepreneurs will start businesses if they have to bear higher cost of starting a businesses. Cost of Starting a business can be high if entrepreneurs have bear long documentations and procedures to register their businesses which may demotivate few entrepreneurs. 
Furthermore, entrepreneurship facilitators can be effected by the role of government regulations and control for corruption. If governments have effective and good regulations and low corruption level than it will motivate entrepreneurs and increase business activities. It means that entrepreneurial facilitators plays a vital role in the growth of new business density.

As shown in Table 6.1, the cost of business has negative and significant impact on HDI in case of both all countries in the world and in their sub groups high-income, high medium-income, medium-income and low-income. The negative impact of cost of business on HDI means if the cost of business is high, it will reduce the capacity of entrepreneurial activity on HDI. Moreover, if cost of business is low, more people may start a business which will increase entrepreneurial activity and have a positive impact on HDI.

Entrepreneurial facilitators is a cross product of new business density and governance factors. Governance factors comprises of two variables such as regulation quality and control for corruption. These two variables may impact the motivation level of entrepreneurs. The results in Table 6.1 shows that in case of all countries in the world and their sub groups high-income, high medium-income, medium-income and low-income countries, there is a positive and significant relationship between governance factors and HDI. Better government regulations and low corruption level may create ease for entrepreneurs in doing business. Moreover, if governments offer grants for startups then it can reduce the cost of business which will increase the capacity of new business to increase HDI and reduce poverty. If government regulations are strict then it may create hurdles for entrepreneurs. Strict regulations can be in a way of long documentation procedures to register a business. So such regulations will consume entrepreneurs' time, money and energy.

Better governance can motivate people to start a business. Effective government regulations can assist people to start a business. If more businesses are registered, there will be more jobs available in market which will reduce poverty. If a country has good governance and less corruption, more businesses will be registered. This can explain why the rate of businesses registered in high-income and high medium-income and medium-income countries is higher than the rate of businesses registered in low-income countries. Because of bad governance and high level of corruption, people either don't operate a business or they operate in an illegal way where they don't pay taxes or fulfill the required procedure of registering their business. The level of 
corruption changes in both developed and developing countries based on the quality of governance. Similarly, in some countries corporate corruption can demotivate young entrepreneurs by creating barriers of entry, promoting the monopoly of the existing firms and unnecessary rise in the cut throat competitions.

Furthermore, the positive impact of governance factor in case of both all countries in the world and in their sub groups high-income, high medium-income, medium-income and lowincome countries shows that if the regulations are good and there is less corruption then more people may start a business which will increase entrepreneurial activities and have positive impact on HDI.

\section{Control Variables and Their Relationship with HDI}

The results as showed in Table 6.1, in case of all countries there is positive and significant relationship between trade openness and HDI. Similarly, in case of high-income and high medium-income countries, there is negative and significant relationship between trade openness and HDI. In case of medium-income countries, there is positive and significant impact of trade openness on HDI whereas in case of low-income countries, trade openness has negative but insignificant impact on HDI.

High-income and high medium-income countries are already developed in terms of infrastructure and capital, so because of that investment returns are lower whereas, mediumincome countries are developing and they have high return based investment opportunities available. Hence when borders open (trade openness increases) the investors including entrepreneurs will try to move out of developed countries for higher returns in developing countries. This is called catch up effect by diminishing returns in developed countries (The Economic Times, 2018).

Tertiary education enrollment also plays an important role in the development of HDI. As shown in Table 6.1, the results show that there is positive and significant relationship between tertiary enrollment and HDI in case of all countries in the world and in their sub groups high medium-income, medium-income and low-income countries. And in case of high-income countries the results show that there is a positive and insignificant relationship between tertiary enrollment and HDI. Various steps can be taken to improve the quality of human capital such as 
training, workshops and education. Education and training will help people to learn new knowledge and skills which help them to improve the quality of life of their masses. The components which develop the process of entrepreneurial activities are high motivation and good educational background.

The relationship between interest rates and human development index (HDI) is shown in Table 6.1. The results show that in case of all countries in the world, there is negative and significant impact of interest rates on HDI. Similarly in case of high-income, high mediumincome, and medium-income, there is negative and significant impact of interest rates on HDI. And in case of low-income countries the results show that there is positive and significant relationship between interest rate and HDI.

In case of high-income, high medium-income and medium-income countries, the results show that there is negative and significant impact of interest rate on HDI. If an entrepreneur has issues in accessing finance then he has to bear high interest of bank loans so that he can start a business. In this case, high cost of starting a new business will demotivate entrepreneurs. High cost of starting a new business will reduce the total number of business registration which will reduce HDI. Low interest rates is one of the key factor in high-income and high-medium income countries which motivates people to start business.

When examining the impacts of interest rates on HDI, there are some unusual results. It might be expected that higher interest rates reduce entrepreneurial activity and this is indeed the case for high-income, high medium-income, and medium-income countries, however, unexpectedly for low-income countries it has actually the positive impact and it is not clear why this should be the case.

\section{Summary}

Overall, results showed that there is positive and significant impact of entrepreneurial activity on HDI in both all countries in the world and their sub sets. Moreover, entrepreneurship facilitators increases the effectiveness and capacity of entrepreneurial activity to reduce poverty. Also, better government regulations and control for corruption help entrepreneurs to start their businesses which will enhance entrepreneurial activities and increase HDI. Furthermore, 
controlling factors such as trade openness, tertiary enrollment, and interest rates have significant effect on poverty.

This suggests that governments should improve the quality of their regulations and reduce the procedures for registering a business. This should reduce the corruption level and allow entrepreneurs to more easily fulfill the documentation requirements. Moreover, consistency in economic growth will attract foreign investors. Furthermore, by investing on education and improving the quality of legislations, government can motivate people to become entrepreneur which will be a right step in reducing the ratio of extreme poverty in a country. 


\section{CHAPTER 7}

\section{Conclusion}

Overall this research project has demonstrated that there is a significant and positive relationship between entrepreneurial activity and poverty reduction as measured by changes in the Human Development Index (HDI). Moreover, the results showed that in entrepreneurial facilitators, cost of business as measured by (average of time required to start the business, number of procedures required, and cost to start a business) have significant impacts on the relationship between entrepreneurial activity and poverty alleviation as measured by HDI. And the governance factors as measured by (average of regulatory quality and control for corruption) have significant impacts in both all countries in the world and their sub groups except low-income countries, on the relationship between entrepreneurial activity and poverty alleviation as measured by HDI.

The study has employed a linear regression model estimated by Panel Generalized Least Square estimation technique. Additionally, the current research used annual cross-sectional time series (panel) data of above mentioned variables are collected for a period of 2005 to 2016.

The merits of entrepreneurship can be far reaching, not only can it benefit individuals, it is expected that its benefit spills over to society. The objective of this study was to investigate the impact of entrepreneurial activity proxied by new business density, entrepreneurial facilitators proxied by cost of business and governance factors such as regulatory quality and control for corruption and economic indicators including interest rate, tertiary enrollment, and trade openness on the dependent variable such as poverty measured by HDI. This analysis was done for highincome, high medium-income, medium-income, low-income and overall.

The study findings demonstrate that entrepreneurial activity has direct and significant effect on HDI for all countries. Moreover, estimated results suggest that the moderating role of entrepreneurial facilitator like cost of business have inverse and significant relationship with HDI in case of all countries. Furthermore, the moderating role of other entrepreneurial facilitator like governance factors have positive and significant relationship with HDI in case of all countries.

Meanwhile, economic indicators including interest rate, tertiary enrollment, and trade openness are directly influencing the HDI. 


\subsection{Contribution}

This is a new and in-depth piece of work, using changes in the Human Development Index to measure poverty reduction, providing a more comprehensive and comparative indicator which was able to respond to the research questions.

It supports the claims that entrepreneurial activity can reduce poverty and improve people's quality of life. It demonstrate a strong correlation between entrepreneurial activity and poverty alleviation. However, it also raises questions about the role of entrepreneurship activity in poorer nations in poverty alleviation.

\subsection{Limitations and Future Research}

This thesis discussed the concept of entrepreneurship and its role in poverty alleviation in detail and illustrated the impact of entrepreneurial activity on poverty alleviation. It has some inherent limitations:

First, there are many definitions of poverty and HDI is one possible measure but others might be considered. Second, within the four country groups (high-income, high medium-income, medium-income and low-income) each country might have its own type and dimension of poverty. Third, due to lack of availability of data, some countries, particularly low-income countries were not used by the model in analysis, because of lack of data. This is a concern, since these countries are those that have the highest levels of poverty.

It might also be worthwhile to consider other control variables such as cost required to export, cost required to import and strength of governance structure.

The above limitations will provide an opportunity that can possibly lead to further studies in entrepreneurship and poverty alleviation. This can include consideration of more control variables to see its impact on entrepreneurial activity and poverty, also the results might be examined further by doing analysis by region. 


\section{References}

Abdullah, M. A. (1999). The accessibility of the government-sponsored support programs for small and medium-sized enterprises in Penang. Cities, 16(2), 83-92. https://doi.org/10.1016/S02642751(99)00003-7

Acemoglu, D., \& Robinson, J. A. (2013). Why Nations Fail: The Origins of Power, Prosperity, and Poverty. Crown Publishers.

Acs, Z. J. (2006). How Is Entrepreneurship Good for Economic Growth? Innovations: Technology, Governance, Globalization, 1(1), 97-107.

Acs, Z. J., \& Amorós, J. E. (2008). Entrepreneurship and competitiveness dynamics in Latin America. Small Business Economics, 31(3), 305-322. https://doi.org/10.1007/s11187-008-9133-y

Acs, Z. J., Arenius, P., \& Minniti, M. (2004). Global Entrepreneurship Monitor.

Acs, Z. J., Audretsch, D. B., Braunerhjelm, P., \& Carlsson, B. (2012). Growth and entrepreneurship. Small Business Economics, 39(2), 289-300. https://doi.org/10.1007/s11187-010-9307-2

Acs, Z. J., Audretsch, D. B., \& Evans, D. S. (1994). Why Does the Self-Employment Rate Vary Across Countries and Over Time? (CEPR Discussion Papers No. 871). C.E.P.R. Discussion Papers. Retrieved from https://ideas.repec.org/p/cpr/ceprdp/871.html

Acs, Z. J., Autio, E., \& Szerb, L. (2014). National Systems of Entrepreneurship: Measurement issues and policy implications. Research Policy, 43(3), 476-494. https://doi.org/10.1016/j.respol.2013.08.016

Acs, Z. J., \& Storey, D. (2004). Introduction: Entrepreneurship and Economic Development. Regional Studies, 38(8), 871-877. https://doi.org/10.1080/0034340042000280901

Adenutsi, D. E. (2009). Entrepreneurship, job creation, income empowerment and poverty reduction in low-income economies. Munich Personal RePEc Archive (MPRA), 29569, 1-21.

Ahlstrom, D. (2010). Innovation and Growth: How Business Contributes to Society. The Academy of Management Perspectives, 24(3), 11-24.

Ahlstrom, D., Levitas, E., Hitt, M. A., Dacin, M. T., \& Zhu, H. (2014). The three faces of China: Strategic alliance partner selection in three ethnic Chinese economies. Journal of World Business, 49(4), 572-585. https://doi.org/10.1016/j.jwb.2013.12.010

Aidis, R., Estrin, S., \& Mickiewicz, T. (2008). Institutions and entrepreneurship development in Russia: A comparative perspective. Journal of Business Venturing, 23(6), 656-672. https://doi.org/10.1016/j.jbusvent.2008.01.005

Alvarez, S. A., \& Barney, J. B. (2014). Entrepreneurial Opportunities and Poverty Alleviation. Entrepreneurship Theory and Practice, 38(1), 159-184. https://doi.org/10.1111/etap.12078

Alvarez, S. A., Barney, J. B., \& Anderson, P. (2012). Forming and Exploiting Opportunities: The Implications of Discovery and Creation Processes for Entrepreneurial and Organizational Research. Organization Science, 24(1), 301-317. https://doi.org/10.1287/orsc.1110.0727

Anokhin, S., \& Schulze, W. S. (2009). Entrepreneurship, innovation, and corruption. Journal of Business Venturing, 24(5), 465-476. https://doi.org/10.1016/j.jbusvent.2008.06.001 
Arshed, N., Alamgir, S., \& Aziz, O. (2017). Structural Determinants of Poverty in Pakistan. International Journal of Economics and Financial Research, 3(1), 1-7.

Arshed, N., Anwar, A., Kousar, N., \& Bukhari, S. (2017). Education Enrollment Level and Income Inequality: A Case of SAARC Economies. Social Indicators Research. https://doi.org/10.1007/s11205-017-1824-9

Audretsch, D. B., \& Keilbach, M. (2004). Entrepreneurship and regional growth: an evolutionary interpretation. Journal of Evolutionary Economics, 14(5), 605-616. https://doi.org/10.1007/s00191-004-0228-6

Austin, J., Stevenson, H., \& Wei-Skillern, J. (2006). Social and Commercial Entrepreneurship: Same, Different, or Both? Entrepreneurship Theory and Practice, 30(1), 1-22. https://doi.org/10.1111/j.1540-6520.2006.00107.x

Autio, E., \& Fu, K. (2015). Economic and political institutions and entry into formal and informal entrepreneurship. Asia Pacific Journal of Management, 32(1), 67-94. https://doi.org/10.1007/s10490-014-9381-0

Avnimelech, G., Zelekha, Y., \& Sharabi, E. (2014). The effect of corruption on entrepreneurship in developed vs non-developed countries. International Journal of Entrepreneurial Behavior \& Research, 20(3), 237-262. https://doi.org/10.1108/IJEBR-10-2012-0121

Bagheri, A., \& Pihie, Z. A. L. (2010). Entrepreneurial Leadership Learning: In Search of Missing Links. Procedia - Social and Behavioral Sciences, 7(Supplement C), 470-479. https://doi.org/10.1016/j.sbspro.2010.10.064

Bamford, C. E., Dean, T. J., \& McDougall, P. P. (2000). An examination of the impact of initial founding conditions and decisions upon the performance of new bank start-ups. Journal of Business Venturing, 15(3), 253-277. https://doi.org/10.1016/S0883-9026(98)00011-1

Banerjee, A. V., \& Duflo, E. (2007). The Economic Lives of the Poor. Journal of Economic Perspectives, 21(1), 141-168. https://doi.org/10.1257/jep.21.1.141

Barney, J. (1991). Firm Resources and Sustained Competitive Advantage. Journal of Management, 17(1), 99-120. https://doi.org/10.1177/014920639101700108

Baron, R., \& Shane, S. A. (2007). Entrepreneurship: A Process Perspective. Nelson Education.

Barseghyan, L. (2008). Entry costs and cross-country differences in productivity and output. Journal of Economic Growth, 13(2), 145-167. https://doi.org/10.1007/s10887-008-9026-6

Baumol, W. J. (1993). Formal entrepreneurship theory in economics: Existence and bounds. Journal of Business Venturing, 8(3), 197-210. https://doi.org/10.1016/0883-9026(93)90027-3

Baumol, W. J. (1996). Entrepreneurship: Productive, unproductive, and destructive. Journal of Business Venturing, 11(1), 3-22. https://doi.org/10.1016/0883-9026(94)00014-X

Bettis, R. A., \& Hitt, M. A. (1995). The new competitive landscape. Strategic Management Journal, 16(S1), 7-19. https://doi-org.ezproxy.lib.ryerson.ca/10.1002/smj.4250160915

Bhagwati, J., \& Srinivasan, T. N. (2002). Trade and Poverty in the Poor Countries. The American Economic Review, 92(2), 180-183. 
Bjørnskov, C., \& Foss, N. (2010). Economic Freedom and Entrepreneurial Activity: Some Cross-Country Evidence. In Entrepreneurship and Culture (pp. 201-225). Springer, Berlin, Heidelberg. https://doi.org/10.1007/978-3-540-87910-7_10

Blackwood, D. L., \& Lynch, R. G. (1994). The measurement of inequality and poverty: A policy maker's guide to the literature. World Development, 22(4), 567-578. https://doi.org/10.1016/0305-750X (94)90112-0

Blau, D. M. (1987). A Time-Series Analysis of Self-Employment in the United States. Journal of Political Economy, 95(3), 445-467. https://doi.org/10.1086/261466

Bosma, N., Acs, Z. J., Autio, E., \& Coduras, A. (2008). Global Entrepreneurship Monitor (Executive Report) (pp. 1-67).

Bowen, H. P., \& Clercq, D. D. (2008). Institutional context and the allocation of entrepreneurial effort. Journal of International Business Studies, 39(4), 747-767. https://doi.org/10.1057/palgrave.jibs.8400343

Brandstätter, H. (1997). Becoming an entrepreneur - A question of personality structure? Journal of Economic Psychology, 18(2), 157-177. https://doi.org/10.1016/S0167-4870(97)00003-2

Branstetter, L., Lima, F., Taylor, L. J., \& Venâncio, A. (2014). Do Entry Regulations Deter Entrepreneurship and Job Creation? Evidence from Recent Reforms in Portugal. The Economic Journal, 124(577), 805-832. https://doi-org.ezproxy.lib.ryerson.ca/10.1111/ecoj.12044

Brockhaus, R. H. (1980). Risk Taking Propensity of Entrepreneurs. Academy of Management Journal, 23(3), 509-520. https://doi.org/10.5465/255515

Bruton, G. D., Ahlstrom, D., \& Si, S. (2015). Entrepreneurship, poverty, and Asia: Moving beyond subsistence entrepreneurship. Asia Pacific Journal of Management, 32(1), 1-22. https://doi.org/10.1007/s10490-014-9404-x

Bruton, G. D., Ketchen, D. J., \& Ireland, R. D. (2013). Entrepreneurship as a solution to poverty. Journal of Business Venturing, 28(6), 683-689. https://doi.org/10.1016/j.jbusvent.2013.05.002

Bruton, G. D., Khavul, S., \& Chavez, H. (2011). Microlending in emerging economies: Building a new line of inquiry from the ground up. Journal of International Business Studies, 42(5), 718-739. https://doi.org/10.1057/jibs.2010.58

Burgelman, R. A. (1983). Corporate Entrepreneurship and Strategic Management: Insights from a Process Study. Management Science, 29(12), 1349-1364. https://doi.org/10.1287/mnsc.29.12.1349

Busenitz, L. W., \& Barney, J. B. (1997). Differences between entrepreneurs and managers in large organizations: Biases and heuristics in strategic decision-making. Journal of Business Venturing, 12(1), 9-30. https://doi.org/10.1016/S0883-9026(96)00003-1

Cajueiro, D. O., \& G, J. (2011). Bank capital buffers, lending growth and economic cycle: empirical evidence for Brazil.

Cantillon, R. (1756). Essai sur la Nature du Commerce.

Capelli, C., \& Vaggi, G. (2013). A better indicator of standards of living: The Gross National Disposable Income (DEM Working Papers Series No. 062). University of Pavia, Department of Economics and Management. Retrieved from https://ideas.repec.org/p/pav/demwpp/demwp0062.html 
Carland, J. W., Hoy, F., Boulton, W. R., \& Carland, J. A. C. (1984). Differentiating Entrepreneurs from Small Business Owners: A Conceptualization. Academy of Management Review, 9(2), 354-359. https://doi.org/10.5465/AMR.1984.4277721

Carree, M., Stel, A. V., Thurik, R., \& Wennekers, S. (2002). Economic Development and Business Ownership: An Analysis Using Data of 23 OECD Countries in the Period 1976-1996. Small Business Economics, 19(3), 271-290. https://doi.org/10.1023/A:1019604426387

Carree, M., Stel, A. V., Thurik, R., \& Wennekers, S. (2007). The relationship between economic development and business ownership revisited. Entrepreneurship \& Regional Development, 19(3), 281-291. https://doi.org/10.1080/08985620701296318

Carter, N. M., Gartner, W. B., Shaver, K. G., \& Gatewood, E. J. (2003). The career reasons of nascent entrepreneurs. Journal of Business Venturing, 18(1), 13-39. https://doi.org/10.1016/S08839026(02)00078-2

Casson, M. (1982). The Entrepreneur: An Economic Theory. Rowman \& Littlefield.

Cauthen, N. K., \& Fass, S. (2008). Measuring Poverty in the United States (pp. 1-4). National Center for Children in Poverty.

Chandler, G. N., \& Hanks, S. H. (1994). Market attractiveness, resource-based capabilities, venture strategies, and venture performance. Journal of Business Venturing, 9(4), 331-349. https://doi.org/10.1016/0883-9026(94)90011-6

Chen, C. C., Greene, P. G., \& Crick, A. (1998). Does entrepreneurial self-efficacy distinguish entrepreneurs from managers? Journal of Business Venturing, 13(4), 295-316. https://doi.org/10.1016/S0883-9026(97)00029-3

Chen, D., \& Mintz, J. M. (2005). How To Become Seductive: Make Canada More Investment-Friendly.

Chiles, T. H., Bluedorn, A. C., \& Gupta, V. K. (2007). Beyond Creative Destruction and Entrepreneurial Discovery: A Radical Austrian Approach to Entrepreneurship. Organization Studies, 28(4), 467493. https://doi.org/10.1177/0170840606067996

Chowdhury, F., Desai, S., \& Audretsch, D. B. (2017). Corruption, Entrepreneurship, and Social Welfare: A Global Perspective. Springer.

Choy, L., \& Chong. (1986). The Entrepreneur as a Social Person: Implications for Entrepreneurial Promotion and Development in Singapore. Journal of Small Business \& Entrepreneurship, 4(2), 34-41. https://doi.org/10.1080/08276331.1986.10600260

Ciccone, A., \& Papaioannou, E. (2007). Red Tape and Delayed Entry. Journal of the European Economic Association, 5(2-3), 444-458. https://doi.org/10.1162/jeea.2007.5.2-3.444

Claessens, S., \& Laeven, L. (2004). What Drives Bank Competition? Some International Evidence. Journal of Money, Credit, and Banking, 36(3), 563-583. https://doi.org/10.1353/mcb.2004.0044

Clark, H. (2011). Accelerating poverty reduction and sustainable human development. China: Global Poverty Reduction and Development Forum.

Cohen, D., \& Soto, M. (2007). Growth and human capital: good data, good results. Journal of Economic Growth, 12(1), 51-76. https://doi.org/10.1007/s10887-007-9011-5

Cole, A. H. (1959). Business enterprise in its social setting. Cambridge, Mass: Harvard University Press. 
Collins, L. A., Smith, A. J., \& Hannon, P. D. (2006). Applying a Synergistic Learning Approach in Entrepreneurship Education. Management Learning, 37(3), 335-354. https://doi.org/10.1177/1350507606067171

Cooper, A. C., Woo, C. Y., \& Dunkelberg, W. C. (1988). Entrepreneurs' perceived chances for success. Journal of Business Venturing, 3(2), 97-108. https://doi.org/10.1016/0883-9026(88)90020-1

Cooper, A. C., Woo, C. Y., \& Dunkelberg, W. C. (1989). Entrepreneurship and the initial size of firms. Journal of Business Venturing, 4(5), 317-332. https://doi.org/10.1016/0883-9026(89)90004-9

Coulter, M. K. (2001). Entrepreneurship in action. Prentice Hall.

Cunningham, J. B., \& Lischeron, J. (1991). Defining Entrepreneurship. Journal of Small Business Management; Milwaukee, 29(1), 45.

Currie-Alder, B., Kanbur, R., Malone, D. M., \& Medhora, R. (2014). International Development: Ideas, Experience, and Prospects. OUP Oxford.

Dahmén, E. (1970). Entrepreneurial Activity and the Development of Swedish Industry: 1919-1939. American Economic Association.

Davidsson, P. (2001). Towards a paradigm for entrepreneurship research. Presented at the RENT Conference, Finland: Turkku.

Davidsson, P. (2003). The domain of entrepreneurship research: some suggestions. In Cognitive Approaches to Entrepreneurship Research (Vol. 6, pp. 315-372). Emerald Group Publishing Limited. https://doi.org/10.1016/S1074-7540(03)06010-0

Davidsson, P., \& Honig, B. (2003). The role of social and human capital among nascent entrepreneurs. Journal of Business Venturing, 18(3), 301-331. https://doi.org/10.1016/S0883-9026(02)00097-6

De Soto, H. (1989). The other path. New York: Harper \& Row.

Dean, T. J. (2016). New Venture Formations in United States Manufacturing: The Role of Industry Environments. Routledge.

Dhawan, B. D., \& Datta, H. S. (1992). Impact of Irrigation on Multiple Cropping. Economic and Political Weekly, 27(13), A15-A18.

Djankov, S., La Porta, R., Lopez-de-Silanes, F., \& Shleifer, A. (2002). The Regulation of Entry. The Quarterly Journal of Economics, 117(1), 1-37. https://doi.org/10.1162/003355302753399436

Dollar, D. (1992). Outward-Oriented Developing Economies Really Do Grow More Rapidly: Evidence from 95 LDCs, 1976-1985. Economic Development and Cultural Change, 40(3), 523-544. https://doi.org/10.1086/451959

Dollar, D. (2005). Globalization, Poverty, and Inequality since 1980. The World Bank Research Observer, 20(2), 145-175. https://doi.org/10.1093/wbro/lki008

Dollar, D., \& Kraay, A. (2002). Growth is Good for the Poor. Journal of Economic Growth, 7(3), 195-225. https://doi.org/10.1023/A:1020139631000

Draft, R. L., \& Marcic, D. (2006). Understanding Management (5th ed.). Thomson Learning Inc.

Dreher, A., \& Gassebner, M. (2007). Greasing the Wheels of Entrepreneurship? Impact of Regulations and Corruption on Firm Entry (SSRN Scholarly Paper No. ID 989301). Rochester, NY: Social Science Research Network. Retrieved from https://papers.ssrn.com/abstract=989301 
Drucker, P. (1985). Innovation and Entrepreneurship. New York: Harper \& Row.

Dunkelberg, W. C., \& Cooper, A. C. (1982). Entrepreneurial Typologies. Babson, College: Wellesley, M A,.

Easterly, W. (2006). The White Man's Burden: Why the West's Efforts to Aid the Rest Have Done So Much III and So Little Good. Penguin.

Edwards, S. (1998). Openness, Productivity and Growth: What Do We Really Know? The Economic Journal, 108(447), 383-398. https://doi-org.ezproxy.lib.ryerson.ca/10.1111/1468-0297.00293

Eisenhardt, K. M., \& Schoonhoven, C. B. (1990). Organizational Growth: Linking Founding Team, Strategy, Environment, and Growth Among U.S. Semiconductor Ventures, 1978-1988. Administrative Science Quarterly, 35(3), 504-529. https://doi.org/10.2307/2393315

Eisenmann, T. R., Ries, E., \& Dillard, S. (2012, April 9). Hypothesis-Driven Entrepreneurship: The Lean Startup. Harvard Business School Entrepreneurial Management Case. Retrieved from https://papers.ssrn.com/sol3/papers.cfm?abstract_id=2037237

Estrin, S., \& Mickiewicz, T. (2012). Shadow Economy and Entrepreneurial Entry. Review of Development Economics, 16(4), 559-578. https://doi.org/10.1111/rode.12004

Fairlie, R. W. (2013). Entrepreneurship, Economic Conditions, and the Great Recession. Journal of Economics \& Management Strategy, 22(2), 207-231. https://doi.org/ttps://doi.org/10.1111/jems.12017

Falkäng, J., \& Alberti, F. (2000). The Assessment of Entrepreneurship Education. Industry and Higher Education, 14(2), 101-108. https://doi.org/10.5367/000000000101294931

Feldman, D. C., \& Bolino, M. C. (2000). Career patterns of the self-employed: Career motivations and career outcomes. Journal of Small Business Management; Milwaukee, 38(3), 53-67.

Fisman, R., \& Allende, V. S. (2010). Regulation of entry and the distortion of industrial organization. Journal of Applied Economics, 13(1), 91-111. https://doi.org/10.1016/S1514-0326(10)60005-0

Friedman, E., Johnson, S., Kaufmann, D., \& Zoido-Lobaton, P. (2000). Dodging the grabbing hand: the determinants of unofficial activity in 69 countries. Journal of Public Economics, 76(3), 459-493. https://doi.org/10.1016/S0047-2727(99)00093-6

Gabriel, D. D. (2013). Inductive and deductive approaches to research. Retrieved April 22, 2018, from http://deborahgabriel.com/2013/03/17/inductive-and-deductive-approaches-to-research/

GAN Business Anti-Corruption. (2017, December). Pakistan Corruption Report. Retrieved from http://www.business-anti-corruption.com/country-profiles/pakistan

Gartner, W. B. (1988). "Who Is an Entrepreneur?" Is the Wrong Question "Who Is an Entrepreneur?" Is the Wrong Question. American Journal of Small Business, 12(4), 11-32. https://doi.org/10.1177/104225878801200401

Georgiou, M. N. (2009a). Entrepreneurship and Human Development Index - a Panel Data Analysis for Western Europe, Japan and the United States (1980-2006) (SSRN Scholarly Paper No. ID 1523605). Rochester, NY: Social Science Research Network. Retrieved from https://papers.ssrn.com/abstract=1523605

Georgiou, M. N. (2009b). Entrepreneurship Causes Economic Growth: An Empirical Analysis for Western European Countries and the United States 1990-2004 (SSRN Scholarly Paper No. ID 1478903). 
Rochester, NY: Social Science Research Network. Retrieved from https://papers.ssrn.com/abstract=1478903

Georgiou, M. N. (2009c). Entrepreneurship Reduces Income Inequality (SSRN Scholarly Paper No. ID 1485704). Rochester, NY: Social Science Research Network. Retrieved from https://papers.ssrn.com/abstract=1485704

Gholami, A., \& Firozjaii, B. A. (2012). The relationship between corruption and entrepreneurship by using panel data model. Journal of Economic Development Research, 1(3), 167-191.

Gnyawali, D. R., \& Fogel, D. S. (1994). Environments for Entrepreneurship Development: Key Dimensions and Research Implications. Entrepreneurship Theory and Practice, 18(4), 43-62. https://doi.org/10.1177/104225879401800403

Godiwalla, Y. H., \& Godiwalla, S. Y. (2002). Marketing issues for the hospital industry. International Journal of Health Care Quality Assurance, 15(1), 25-28. https://doi.org/10.1108/09526860210415588

Goldsmith, R. E., \& Kerr, J. R. (1991). Entrepreneurship and adaption-innovation theory. Technovation, 11(6), 373-382. https://doi.org/10.1016/0166-4972(91)90019-Z

Goldsmith, W., \& Blakely, E. (1991). Separate Societies: Poverty and Inequality in U.S. Cities. Temple University Press.

Gould, D. M. (1998). Has NAFTA changed North American trade? Economic Review-Federal Reserve Bank of Dallas. Retrieved from https://search.proquest.com/openview/211cf91e654cc4d80b0b295c63d18ff1/1?pqorigsite $=$ gscholar $\& \mathrm{cbl}=37664$

Government of Canada. (2014, December 18). Business grants and financing [navigation page - topic page]. Retrieved from https://www.canada.ca/en/services/business/grants.html

Grant, K. A., Padmanaban, D., \& Kebbi, A. E. (2018). The Early Investment Ecosystem for Startups in Canada, a Preliminary Study. Kindai Management Review, 6.

Greene, W. (2003). Econometric Analysis. Pearson Education India.

Grilo, I., \& Irigoyen, J.-M. (2006). Entrepreneurship in the EU: To Wish and not to be. Small Business Economics, 26(4), 305-318. https://doi.org/10.1007/s11187-005-1561-3

Guasch, J. L., \& Hahn, R. W. (1999). The Costs and Benefits of Regulation: Implications for Developing Countries. The World Bank Research Observer, 14(1), 137-158. https://doi.org/10.1093/wbro/14.1.137

Gujarati, D. N. (2009). Basic econometrics. McGraw Hill.

Guth, W. D., \& Arun, K. (1991). Cognition, Enactment, and Learning in the Entrepreneurial Process. In Eleventh Annual Babson College Entrepreneurship Research Conference. Churchill.

Harrison, A. (1996). Openness and growth: A time-series, cross-country analysis for developing countries. Journal of Development Economics, 48(2), 419-447. https://doi.org/10.1016/03043878(95)00042-9

Hessels, J., Gelderen, M. van, \& Thurik, R. (2008). Entrepreneurial aspirations, motivations, and their drivers. Small Business Economics, 31(3), 323-339. https://doi.org/10.1007/s11187-008-9134-x 
Hill, J., \& McGowan, P. (1999). A qualitative approach to developing small firm marketing planning competencies. Qualitative Market Research: An International Journal, 2(3), 167-175. https://doi.org/10.1108/13522759910291662

Hisrich, R. D., \& Peters, M. P. (1989). Entrepreneurship: starting, developing and managing a new enterprise. Homewood, IL: BPI, Irwin.

Hollingsworth, Abner, T., \& Herbert, H. H. A Guide to Small Business Management, Philadelphia: Saunders (1979).

Hornaday, J. A., \& Aboud, J. (1971). Characteristics of Successful Entrepreneurs1. Personnel Psychology, 24(2), 141-153. https://doi.org/10.1111/j.1744-6570.1971.tb02469.x

Hussain, I., \& Hanjra, M. A. (2004). Irrigation and poverty alleviation: review of the empirical evidence. Irrigation and Drainage, 53(1), 1-15. https://doi-org.ezproxy.lib.ryerson.ca/10.1002/ird.114

Hussain, M. D., Bhuiyan, A. B., \& Bakar, R. (2014). Entrepreneurship Development and Poverty Alleviation: An Empirical Review. Journal of Asian Scientific Research, 4(10), 558-573.

Jain, R., \& Ali, S. W. (2013). A Review of Facilitators, Barriers and Gateways to Entrepreneurship: Directions for Future Research. South Asian Journal of Management, 20(3), 122-163.

Jalilian, H., Kirkpatrick, C., \& Parker, D. (2007). The Impact of Regulation on Economic Growth in Developing Countries: A Cross-Country Analysis. World Development, 35(1), 87-103. https://doi.org/10.1016/j.worlddev.2006.09.005

Jensen, E. (2009). Understanding the Nature of Poverty. Retrieved from http://www.ascd.org/publications/books/109074/chapters/Understanding-the-Nature-ofPoverty.aspx

Johnson, S., Kaufmann, D., \& Zoido-Lobatón, P. (1998). Regulatory Discretion and the Unofficial Economy. The American Economic Review, 88(2), 387-392.

Jones, C. I., \& Romer, P. M. (2010). The New Kaldor Facts: Ideas, Institutions, Population, and Human Capital. American Economic Journal: Macroeconomics, 2(1), 224-245. https://doi.org/10.1257/mac.2.1.224

Jones, M. V., Coviello, N., \& Tang, Y. K. (2011). International Entrepreneurship research (1989-2009): A domain ontology and thematic analysis. Journal of Business Venturing, 26(6), 632-659. https://doi.org/10.1016/j.jbusvent.2011.04.001

Jovanovic, B. (1982). Selection and the Evolution of Industry. Econometrica, 50(3), 649-670. https://doi.org/10.2307/1912606

Kahneman, D., \& Lovallo, D. (1993). Timid Choices and Bold Forecasts: A Cognitive Perspective on Risk Taking. Management Science, 39(1), 17-31. https://doi.org/10.1287/mnsc.39.1.17

Kaish, S., \& Gilad, B. (1991). Characteristics of opportunities search of entrepreneurs versus executives: Sources, interests, general alertness. Journal of Business Venturing, 6(1), 45-61. https://doi.org/10.1016/0883-9026(91)90005-X

Kaldor, N. (1967). Strategic factors in economic development. Retrieved from http://agris.fao.org/agrissearch/search.do?recordID=US201300599872

Kanbur, S. M. (1979). Of Risk Taking and the Personal Distribution of Income. Journal of Political Economy, 87(4), 769-797. https://doi.org/10.1086/260792 
Karayiannis, A. D. (2003). Entrepreneurial functions and characteristics in a proto-capitalist economy the xenophonian entrepreneur. Wirtschaftspolitische Blatter 50, 553-563.

Kareem, R. O. (2015). Impact of Entrepreneurship on Poverty Alleviation. Journal of Business Administration and Education, 7(1), 1-16.

Karlsson, C., Friis, C., \& Paulsson, T. (2004). Relating entrepreneurship to economic growth. Berlin: The Emerging Digital Economy: Entrepreneurship Clusters and Policy. Springer-Verlag.

Keats, B. W., \& Bracker, J. S. (1988). Toward a Theory of Small Firm Performance: A Conceptual Model. American Journal of Small Business, 12(4), 41-58. https://doi.org/10.1177/104225878801200403

Kirzner, I. M. (1973). Competition and entrepreneurship. Chicago: The university of Chicago Press.

Kirzner, I. M. (1979). Perception, opportunity, and profit. Chicago: University of Chicago Press.

Kirzner, I. M. (1997). Entrepreneurial Discovery and the Competitive Market Process: An Austrian Approach. Journal of Economic Literature, 35(1), 60-85.

Klapper, L., Laeven, L., \& Rajan, R. (2006). Entry regulation as a barrier to entrepreneurship. Journal of Financial Economics, 82(3), 591-629. https://doi.org/10.1016/j.jfineco.2005.09.006

Klapper, L., Love, I., \& Randall, D. (2015). New firm registration and the business cycle. International Entrepreneurship and Management Journal, 11(2), 287-306. https://doi.org/10.1007/s11365014-0345-0

Klapper, L., Raphael, A., \& Mauro F., G. (2010). Entrepreneurship And Firm Formation Across Countries (In International differences in entrepreneurship) (pp. 129-158). University of Chicago Press.

Knight, F. (1916). Risk, Uncertainty and Profit. New York: Houghton Mifflin.

Knight, F. H. (1942). Profit and Entrepreneurial Functions. The Journal of Economic History, 2(S1), 126132. https://doi.org/10.1017/S0022050700083479

Kolvereid, L. (1996). Organizational Employment versus Self-Employment: Reasons for Career Choice Intentions. Entrepreneurship Theory and Practice, 20(3), 23-31. https://doi.org/10.1177/104225879602000302

Kolvereid, L., \& Moen, Ø. (1997). Entrepreneurship among business graduates: does a major in entrepreneurship make a difference? Journal of European Industrial Training, 21(4), 154-160. https://doi.org/10.1108/03090599710171404

Krueger, A. O. (1981). Trade and Employment in Developing Countries, Volume 1: Individual Studies. University of Chicago Press.

Krueger, N., \& Dickson, P. R. (1994). How Believing in Ourselves Increases Risk Taking: Perceived SelfEfficacy and Opportunity Recognition. Decision Sciences, 25(3), 385-400. https://doi.org/10.1111/j.1540-5915.1994.tb00810.x

Kuratko, D., \& Hodgetts, R. (2004). Entrepreneurship, theory, process, practice, (6th ed.). Stanford, CT: Thomson South-Western.

La Porta, R., Lopez-de-Silanes, F., Shleifer, A., \& Vishny, R. (1999). The quality of government. The Journal of Law, Economics, and Organization, 15(1), 222-279. https://doi.org/10.1093/jleo/15.1.222 
Lammam, C., \& Maclntyre, H. (2016). An Introduction to the State of Poverty in Canada. Fraser Institute, 43.

Landes, D. S. (1998). The wealth and poverty of nations: why some are so rich and some so poor (1st ed). New York: W.W. Norton.

Landstrom, H. (2007). Pioneers in Entrepreneurship and Small Business Research. Springer.

Lant, P., Klasen, S., Alkire, S., Lenhardt, A., \& Letouzé, E. (2013). Eradicating global poverty: a noble goal, but how do we measure it?

Leff, N. H. (1964). Economic Development Through Bureaucratic Corruption. American Behavioral Scientist, 8(3), 8-14. https://doi.org/10.1177/000276426400800303

Leff, N. H. (1979). Entrepreneurship and Economic Development: The Problem Revisited. Journal of Economic Literature, 17(1), 46-64.

Lerner, J. (2009). Boulevard of Broken Dreams: Why Public Efforts to Boost Entrepreneurship and Venture Capital Have Failed--and What to Do About It. Princeton University Press.

Levie, J., \& Autio, E. (2011). Regulatory Burden, Rule of Law, and Entry of Strategic Entrepreneurs: An International Panel Study. Journal of Management Studies, 48(6), 1392-1419. https://doi.org/10.1111/j.1467-6486.2010.01006.x

Lu, Y., Au, K., Peng, M. W., \& Xu, E. (2013). Strategic management in private and family businesses. Asia Pacific Journal of Management, 30(3), 633-639. https://doi.org/10.1007/s10490-013-9359-3

Lucas, R. E. (1988). On the mechanics of economic development. Journal of Monetary Economics, 22(1), 3-42. https://doi.org/10.1016/0304-3932(88)90168-7

Luke, B., Verreynne, M.-L., \& Kearins, K. (2007). Measuring the benefits of entrepreneurship at different levels of analysis. Journal of Management \&amp; Organization, 13(4), 312-330. https://doi.org/10.1017/S1833367200003576

Lundberg, M., \& Squire, L. (2003). The simultaneous evolution of growth and inequality*. The Economic Journal, 113(487), 326-344. https://doi-org.ezproxy.lib.ryerson.ca/10.1111/1468-0297.00127

Marshall, A. (1890). Principles of Economics. London: MacMillan.

Marshall, A. (1919). Industry and Trade. London: MacMillan.

Mauro, P. (1995). Corruption and Growth. The Quarterly Journal of Economics, 110(3), 681-712. https://doi.org/10.2307/2946696

McClelland, D. C. (1987). Characteristics of Successful Entrepreneurs*. The Journal of Creative Behavior, 21(3), 219-233. https://doi.org/10.1002/j.2162-6057.1987.tb00479.x

McCloskey, D. N. (2010). Bourgeois Dignity: Why Economics Can't Explain the Modern World. University of Chicago Press.

McMullen, J. S. (2011). Delineating the Domain of Development Entrepreneurship: A Market-Based Approach to Facilitating Inclusive Economic Growth. Entrepreneurship Theory and Practice, 35(1), 185-193. https://doi.org/10.1111/j.1540-6520.2010.00428.x

Mead, D. C., \& Liedholm, C. (1998). The Dynamics of Micro and Small Enterprises in Developing Countries. World Development, 26(1), 61-74. https://doi.org/10.1016/S0305-750X(97)10010-9

Menger, C. (1981). 1871, Principles of Economics. New York: University Press. 
Meyer, C., \& Birdsall, N. (2012). New estimates of India's middle class. Center for Global Development, Washington, $D C$.

Meyer, G. D., \& Heppard, K. A. (2000). Entrepreneurship as Strategy: Competing on the Entrepreneurial Edge. SAGE Publications.

Milanovic, B. (2005). Can We Discern the Effect of Globalization on Income Distribution? Evidence from Household Surveys. The World Bank Economic Review, 19(1), 21-44. https://doi.org/10.1093/wber/lhi003

Miller, A., \& Camp, B. (1985). Exploring determinants of success in corporate ventures. Journal of Business Venturing, 1(1), 87-105. https://doi.org/10.1016/0883-9026(85)90009-6

Miller, D. (1983). The Correlates of Entrepreneurship in Three Types of Firms. Management Science, 29(7), 770-791. https://doi.org/10.1287/mnsc.29.7.770

Miller, S., \& Startz, R. (2018). Feasible Generalized Least Squares Using Machine Learning (SSRN Scholarly Paper No. ID 2966194). Rochester, NY: Social Science Research Network. Retrieved from https://papers.ssrn.com/abstract=2966194

Minniti, M. (2013). The Dynamics of Entrepreneurship: Evidence from Global Entrepreneurship Monitor Data. Oxford University Press.

Minniti, M., \& Lévesque, M. (2010). Entrepreneurial types and economic growth. Journal of Business Venturing, 25(3), 305-314. https://doi.org/10.1016/j.jbusvent.2008.10.002

Mises, L. V. (1952). Planning for Freedom, and Other Essays and Addresses. Libertarian Press.

Mitra, J., Abubakar, Y. A., \& Sagagi, M. (2011). Knowledge creation and human capital for development: The role of graduate entrepreneurship. Education + Training, 53(5), 462-479. https://doi.org/10.1108/00400911111147758

Mohd, S. N., Chea, P., \& Juhary, A. (2010). Moderating Effect of Government Policy on Entrepreneurship and Growth Performance of Small-Medium Enterprises in Cambodia. International Journal of Business and Management Science, 3(1), 57-72.

Monsef, A., Sameti, M., \& Mojahednia, M. (2011). The Effect of Intellectual Property Rights and Information and Communication Technology on Human Development Index in Developing Countries During 2005-2010. Australian Journal of Business and Management Research, 1(9), 105-112.

Morris, M. H. (1998). Entrepreneurial Intensity: Sustainable Advantages for Individuals, Organizations, and Societies. Greenwood Publishing Group.

Muravyev, A., Talavera, O., \& Schäfer, D. (2009). Entrepreneurs' gender and financial constraints: Evidence from international data. Journal of Comparative Economics, 37(2), 270-286. https://doi.org/10.1016/j.jce.2008.12.001

Murphy, P. J., \& Coombes, S. M. (2009). A Model of Social Entrepreneurial Discovery. Journal of Business Ethics, 87(3), 325-336. https://doi.org/10.1007/s10551-008-9921-y

Naudé, W. (2007). Peace, prosperity and pro-growth entrepreneurship (Working Paper No. 2007/02). WIDER Discussion Papers, World Institute for Development Economics (UNU-WIDER). Retrieved from https://www.econstor.eu/handle/10419/84657 
Naudé, W. (2010). Entrepreneurship, Developing Countries, And Development Economics: New Approaches And Insights. Small Business Economics, 34(1), 1. https://doi.org/10.1007/s11187009-9198-2

Neck, C. P., \& Manz, C. C. (1992). Thought self-leadership: The influence of self-talk and mental imagery on performance. Journal of Organizational Behavior, 13(7), 681-699. https://doi.org/10.1002/job.4030130705

Nistotskaya, M., \& Cingolani, L. (2016). Bureaucratic Structure, Regulatory Quality, and Entrepreneurship in a Comparative Perspective: Cross-Sectional and Panel Data Evidence. Journal of Public Administration Research and Theory, 26(3), 519-534. https://doi.org/10.1093/jopart/muv026

Norris F. Krueger, J., \& Brazeal, D. V. (1994). Entrepreneurial Potential and Potential Entrepreneurs. Entrepreneurship Theory and Practice, 18(3), 91-104. https://doi.org/10.1177/104225879401800307

Nyström, K. (2008). The institutions of economic freedom and entrepreneurship: evidence from panel data. Public Choice, 136(3-4), 269-282. https://doi.org/10.1007/s11127-008-9295-9

Ogundele, O. J. K. (2001). Determinant of Entrepreneurial Emergence, Behaviour and Performance in Nigeria (Thesis). Retrieved from http://ir.unilag.edu.ng:8080/xmlui/handle/123456789/1219

Ogundele, O. J. K., Akingbade, W. A., \& Akinlabi, H. B. (2012). Entrepreneurship training and education as strategic tools for poverty alleviation in Nigeria. American International Journal of Contemporary Research, 2(1), 148-156.

Okpara, J. O. (2011). Factors constraining the growth and survival of SMEs in Nigeria: Implications for poverty alleviation. Management Research Review, 34(2), 156-171. https://doi.org/10.1108/01409171111102786

Osterwalder, A., \& Pigneur, Y. (2010). Business Model Generation: A Handbook for Visionaries, Game Changers, and Challengers. John Wiley \& Sons.

Parliament of Canada. (2008). Measuring Poverty: A Challenge for Canada (PRB 08-65E). Retrieved from https://lop.parl.ca/content/lop/researchpublications/prb0865-e.htm\#a1

Payne, R. K., Philip, D., \& Smith, T. D. (2001). Based on Bridges Out of Poverty: Strategies for Professionals and Communities. New York: Aha, 44.

Peltzman, S. (1976). Toward a More General Theory of Regulation. The Journal of Law and Economics, 19(2), 211-240. https://doi.org/10.1086/466865

Peng, M. W. (2002). Towards an Institution-Based View of Business Strategy. Asia Pacific Journal of Management, 19(2-3), 251-267. https://doi.org/10.1023/A:1016291702714

Peng, M. W., Sun, S. L., Pinkham, B., \& Chen, H. (2009). The Institution-Based View as a Third Leg for a Strategy Tripod. The Academy of Management Perspectives, 23(3), 63-81. https://doi.org/10.5465/AMP.2009.43479264

Peteraf, M. A. (1993). The cornerstones of competitive advantage: A resource-based view. Strategic Management Journal, 14(3), 179-191. https://doi.org/10.1002/smj.4250140303

Pigou, A. C. (1938). The Economics of Welfare. Palgrave Macmillan.

Posner, R. A. (1975). The Social Costs of Monopoly and Regulation. Journal of Political Economy, 83(4), 807-827. https://doi.org/10.1086/260357 
Powell, B. (Ed.). (2008). Making poor nations rich: entrepreneurship and the process of economic development. Stanford, Calif. : Oakland, Calif: Stanford Economics and Finance ; Published in association with the Independent Institute.

Prahalad, C. K. (2005). Promises and perils at the bottom of the pyramid. Administrative Science Quarterly 50.

Rampini, A. A. (2004). Entrepreneurial activity, risk, and the business cycle. Journal of Monetary Economics, 51(3), 555-573. https://doi.org/10.1016/j.jmoneco.2003.06.003

Rank, M. R. (2004). One Nation, Underprivileged: Why American Poverty Affects Us All. Oxford University Press.

Ravallion, M. (2001). Growth, Inequality and Poverty: Looking Beyond Averages. World Development, 29(11), 1803-1815. https://doi.org/10.1016/S0305-750X(01)00072-9

Ravallion, M. (2006). Looking beyond averages in the trade and poverty debate. World Development, 34(8), 1374-1392. https://doi.org/10.1016/j.worlddev.2005.10.015

Reardon, T., \& Taylor, J. E. (1996). Agroclimatic shock, income inequality, and poverty: Evidence from Burkina Faso. World Development, 24(5), 901-914. https://doi.org/10.1016/0305750X(96)00009-5

Reynolds, P., Bosma, N., Autio, E., Hunt, S., Bono, N. D., Servais, I., ... Chin, N. (2005). Global Entrepreneurship Monitor: Data Collection Design and Implementation 1998-2003. Small Business Economics, 24(3), 205-231. https://doi.org/10.1007/s11187-005-1980-1

Rindova, V., Barry, D., \& Ketchen, D. J. (2009). Entrepreneuring as Emancipation. Academy of Management Review, 34(3), 477-491. https://doi.org/10.5465/AMR.2009.40632647

Rodrik, D., Subramanian, A., \& Trebbi, F. (2004). Institutions Rule: The Primacy of Institutions Over Geography and Integration in Economic Development. Journal of Economic Growth, 9(2), 131165. https://doi.org/10.1023/B:JOEG.0000031425.72248.85

Romanelli, E. (1989). Environments and Strategies of Organization Start-Up: Effects on Early Survival. Administrative Science Quarterly, 34(3), 369-387. https://doi.org/10.2307/2393149

Romer, P. M. (1990). Human capital and growth: Theory and evidence. Carnegie-Rochester Conference Series on Public Policy, 32, 251-286. https://doi.org/10.1016/0167-2231(90)90028-J

Ronstadt, R. C. (1983). Initial venture goals, age, and the decision to start an entrepreneurial career. In Proceedings of the 43rd annual meeting of the Academy of Management (pp. 417-421).

Rothstein, B., \& Teorell, J. (2008). What Is Quality of Government? A Theory of Impartial Government Institutions. Governance, 21(2), 165-190. https://doi.org/10.1111/j.1468-0491.2008.00391.x

Runyan, R. C., Huddleston, P., \& Swinney, J. (2006). Entrepreneurial orientation and social capital as small firm strategies: A study of gender differences from a resource-based view. The International Entrepreneurship and Management Journal, 2(4), 455. https://doi.org/10.1007/s11365-006-0010-3

Sachs, J. (2005). The End of Poverty: Economic Possibilities For Our Time. New York: Penguin Press.

Sachs, J. D., \& Warner, A. M. (1995). Economic Convergence and Economic Policies (Working Paper No. 5039). National Bureau of Economic Research. https://doi.org/10.3386/w5039 
Santos, F. M. (2012). A Positive Theory of Social Entrepreneurship | SpringerLink. Journal of Business Ethics, 111(3), 335-351. https://doi.org/10.1007/s10551-012-1413-4

Say, J. B. (2008). A Treatise on Political Economy. Ludwig von Mises Institute.

Schramm, C. J. (2004). Building Entrepreneurial Economies. Foreign Affairs, 83(4), 104-115. https://doi.org/10.2307/20034050

Schumpeter, J. A. (1934). The theory of economic development: An inquiry into profits, capital, credit, interest, and the business cycle. Harvard University Press.

Schumpeter, J. A. (1942). Capitalism, Socialism and Democracy. Routledge.

Schumpeter, J. A., \& Backhaus, U. (2003). The Theory of Economic Development. In Joseph Alois Schumpeter (pp. 61-116). Springer, Boston, MA. https://doi.org/10.1007/0-306-48082-4_3

Schumpeter, J. A., \& Perlman, M. (1954). History of Economic Analysis. London, UNITED KINGDOM: Routledge. Retrieved from http://ebookcentral.proquest.com/lib/ryerson/detail.action?doclD=256868

Seelos, C., \& Mair, J. (2005). Social entrepreneurship: Creating new business models to serve the poor. Business Horizons, 48(3), 241-246. https://doi.org/10.1016/j.bushor.2004.11.006

Sen, A. (2000). A Decade of Human Development. Journal of Human Development, 1(1), 17-23. https://doi.org/10.1080/14649880050008746

Shahid, Y., Deaton, A., Dervis, K., \& Easterly, W. (2009). Development Economics through the Decades: A Critical Look at 30 Years of the World Development Report. The World Bank. Retrieved from http://hdl.handle.net/10986/2586

Shane, S. A. (2003). A General Theory of Entrepreneurship: The Individual-opportunity Nexus. Edward Elgar Publishing.

Shane, S. A. (2008). The Illusions of Entrepreneurship: The Costly Myths That Entrepreneurs, Investors, and Policy Makers Live By. Yale University Press.

Shane, S. A. (2009). Why encouraging more people to become entrepreneurs is bad public policy. Small Business Economics, 33(2), 141-149. https://doi.org/10.1007/s11187-009-9215-5

Shane, S. A., \& Venkataraman, S. (2000). The Promise of Entrepreneurship as a Field of Research. Academy of Management Review, 25(1), 217-226. https://doi.org/10.5465/AMR.2000.2791611

Shapero, A. (1975). The Displaced, Uncomfortable Entrepreneur (SSRN Scholarly Paper No. ID 1506368). Rochester, NY: Social Science Research Network. Retrieved from https://papers.ssrn.com/abstract=1506368

Shapero, A., \& Sokol, L. (1982). The Social Dimensions of Entrepreneurship (SSRN Scholarly Paper No. ID 1497759). Rochester, NY: Social Science Research Network. Retrieved from https://papers.ssrn.com/abstract=1497759

Shepherd, D. A., \& DeTienne, D. R. (2005). Prior Knowledge, Potential Financial Reward, and Opportunity Identification. Entrepreneurship Theory and Practice, 29(1), 91-112. https://doi.org/10.1111/j.1540-6520.2005.00071.x

Si, S., Yu, X., Wu, A., Chen, S., Chen, S., \& Su, Y. (2015). Entrepreneurship and poverty reduction: A case study of Yiwu, China. Asia Pacific Journal of Management, 32(1), 119-143. https://doi.org/10.1007/s10490-014-9395-7 
Singer, A. E. (2006). Business Strategy and Poverty Alleviation. Journal of Business Ethics, 66(2-3), 225231. https://doi.org/10.1007/s10551-005-5587-x

Smith, A., \& McCulloch, J. R. (1838). An Inquiry Into the Nature and Causes of the Wealth of Nations. A. and C. Black and W. Tait.

Solomon, G. T., \& Winslow, E. K. (1988). Toward A Descriptive Profile of The Entrepreneur. The Journal of Creative Behavior, 22(3), 162-171. https://doi.org/10.1002/j.2162-6057.1988.tb00493.x

Sombart, W. (2013). Krieg und Kapitalismus. BoD - Books on Demand.

Spencer, J. W., \& Gómez, C. (2004). The relationship among national institutional structures, economic factors, and domestic entrepreneurial activity: a multicountry study. Journal of Business Research, 57(10), 1098-1107. https://doi.org/10.1016/S0148-2963(03)00040-7

Stel, A. V., Carree, M., \& Thurik, R. (2005). The Effect of Entrepreneurial Activity on National Economic Growth. Small Business Economics, 24(3), 311-321. https://doi.org/10.1007/s11187-005-1996-6

Stenholm, P., Acs, Z. J., \& Wuebker, R. (2013). Exploring country-level institutional arrangements on the rate and type of entrepreneurial activity. Journal of Business Venturing, 28(1), 176-193. https://doi.org/10.1016/j.jbusvent.2011.11.002

Stevenson, H., \& Gumpert, D. (1985). The Heart of Entrepreneurship. Harvard Business Review.

Stevenson, H., \& Jarillo, J. C. (2007). A Paradigm of Entrepreneurship: Entrepreneurial Management. In Entrepreneurship (pp. 155-170). Springer, Berlin, Heidelberg. https://doi.org/10.1007/978-3540-48543-8_7

Stigler, G. J. (1971). The Theory of Economic Regulation. The Bell Journal of Economics and Management Science, 2(1), 3-21. https://doi.org/10.2307/3003160

Stiglitz, J. E. (2002). Globalization and its Discontents (Vol. 500). New York: W.W. Norton \& Company.

Storey, D. J. (1994). Understanding The Small Business Sector. Routledge.

Syrquin, M. (1988). Chapter 7 Patterns of structural change. In Handbook of Development Economics (Vol. 1, pp. 203-273). Elsevier. https://doi.org/10.1016/S1573-4471(88)01010-1

Tang, L., \& Koveos, P. E. (2004). Venture Entrepreneurship, Innovation Entrepreneurship, and Economic Growth. Journal of Developmental Entrepreneurship; Norfolk, 9(2), 161-171.

The Economic Times. (2018). Catch Up Effect - What is Catch Up Effect ? Catch Up Effect meaning, Catch Up Effect definition. Retrieved November 29, 2018, from https://economictimes.indiatimes.com/definition/catch-up-effect

Timmons, J. A. (1978). Characteristics and Role Demands of Entrepreneurship. American Journal of Small Business, 3(1), 5-17. https://doi.org/10.1177/104225877800300102

Timmons, J. A. (1997). New Venture Creation. Homewood, III.: Irwin.

Timmons, J. A., \& Spinelli, S. (2004). New Venture Creation: Entrepreneurship for the 21st century (Vol. 4). Boston: McGraw Hill Irwin.

Todaro, M. P., \& Smith, S. C. (2003). Economic development (8th ed). Boston ; Toronto: Addison Wesley. Todaro, M. P., \& Smith, S. C. (2012). Economic Development (11th ed.). George Washington University. 
Ucbasaran, D., Wright, M., \& Westhead, P. (2003). A longitudinal study of habitual entrepreneurs: starters and acquirers. Entrepreneurship \& Regional Development, 15(3), 207-228. https://doi.org/10.1080/08985620210145009

UNDP. (2018). Human Development Index (HDI) | Human Development Reports. Retrieved from http://hdr.undp.org/en/content/human-development-index-hdi

United Nations. (2000). United Nations Millennium Declaration. General Assembly.

United Nations. (2015). United Nations Millennium Development Goals. Retrieved October 12, 2018, from http://www.un.org/millenniumgoals/poverty.shtml

Venkataraman, S. (1997). The distinctive domain of entrepreneurship research. Advances in Entrepreneurship, Firm Emergence and Growth, 3(1), 119-138.

Vesper, K. H. (1979). New Venture Ideas: Do not overlook the Experience Factor. Harvard Business Review, 57(4), 164-167.

Wang, C. K., \& Wong, P.-K. (2004). Entrepreneurial interest of university students in Singapore. Technovation, 24(2), 163-172. https://doi.org/10.1016/S0166-4972(02)00016-0

Wennekers, S., \& Thurik, R. (1999). Linking Entrepreneurship and Economic Growth. Small Business Economics, 13(1), 27-56. https://doi.org/10.1023/A:1008063200484

Wennekers, S., Wennekers, A. van, Thurik, R., \& Reynolds, P. (2005). Nascent Entrepreneurship and the Level of Economic Development. Small Business Economics, 24(3), 293-309. https://doi.org/10.1007/s11187-005-1994-8

Wernerfelt, B. (1984). A resource-based view of the firm. Strategic Management Journal, 5(2), 171-180. https://doi.org/10.1002/smj.4250050207

Williams, C. C., \& Nadin, S. (2010). Entrepreneurship and the informal economy: an overview. Journal of Developmental Entrepreneurship, 15(04), 361-378. https://doi.org/10.1142/S1084946710001683

World Bank. (1997). International Bank for Reconstruction and Development (World Development Report).

World Bank. (2002). Globalization, growth, and poverty : building an inclusive world economy (No. 23591) (p. 1). The World Bank. Retrieved from http://documents.worldbank.org/curated/en/954071468778196576/Globalization-growth-andpoverty-building-an-inclusive-world-economy

World Bank. (2016a). Doing Business 2017 - Equal Opportunity for All - World Bank Group. The World Bank. Retrieved from http://www.doingbusiness.org/reports/global-reports/doing-business2017

World Bank. (2016b). Poverty. Retrieved December 24, 2017, from http://www.worldbank.org/en/topic/poverty/overview

World Bank. (2018). GNI per capita, PPP (current international \$) | Data. Retrieved October 18, 2018, from https://data.worldbank.org/indicator/NY.GNP.PCAP.PP.CD

World Bank Group. (2011). Helping Small Businesses in Pakistan. Retrieved from http://www.ifc.org/wps/wcm/connect/NEWS_EXT_CONTENT/IFC_External_Corporate_Site/Ne ws+and+Events/News/Helping+Small+Businesses+in+Pakistan 
Yassin, S. A., \& Abdel, H. A. (2013). Entrepreneurship Development and Poverty Reduction: Empirical Survey from Somalia. American International Journal of Social Science, 2(3), 108-113.

Yunus, M. (2007). Banker To The Poor. Penguin Books India. 